\title{
2. OLIGOCENE TO PLEISTOCENE BENTHIC FORAMINIFER ASSEMBLAGES AT SITES 754 AND 756, EASTERN INDIAN OCEAN ${ }^{1}$
}

\author{
Ritsuo Nomura ${ }^{2}$
}

\begin{abstract}
Oligocene to Pleistocene bathyal benthic foraminifers at Broken Ridge (Site 754) and Ninetyeast Ridge (Site 756), eastern Indian Ocean, were investigated for their stratigraphic distribution and their response to paleoceanographic changes. Q-mode factor analysis was applied to relative abundance data of the most abundant benthic foraminifers.

At Site 754, seven varimax assemblages were recognized from the upper Oligocene to the Pleistocene: the Gyroidina orbicularis-Rectuvigerina striata Assemblage in the uppermost Oligocene; the Lenticulina spp. Assemblage in the upper Oligocene to lower Miocene, and in lower Miocene to lowermost middle Miocene; the Burseolina cf. pacifica-Cibicidoides mundulus Assemblage in the lower Miocene; the Planulina wuellerstorfi Assemblage in the upper middle Miocene; the Globocassidulina spp. Assemblage in the upper Miocene; the Gavelinopsis lobatulus-Uvigerina proboscidea Assemblage in the Pliocene; and the Ehrenbergina spp. Assemblage in the Pleistocene. The major faunal changes are complex, but exist between the Lenticulina spp. Assemblage and the $P$. wuellerstorfi Assemblage at $\sim 13.8 \mathrm{Ma}$, and between the Ehrenbergina spp. Assemblage and the $G$. lobatulus Assemblage at $\sim 5 \mathrm{Ma}$. The development of the $P$. wuellerstorfi and Globocassidulina spp. Assemblages after $13.8 \mathrm{Ma}$ is correlated with the decrease in temperature of the intermediate waters of the ocean, in turn related to Antarctic glacial expansion. The faunal changes at $\sim 5 \mathrm{Ma}$ are related to the development of low oxygen intermediate water, formed in the presence of a strong thermocline.

At Site 756, six varimax assemblages are distributed as follows: the Cibicidoides $\mathrm{cf}$. mundulus-Oridorsalis umbonatus Assemblage in the lower Oligocene; the Epistominella umbonifera-Cibicidoides mundulus Assemblage from the upper Oligocene to the lower Miocene; the Cibicidoides mundulus-Burseolina pacifica Assemblage from lower Miocene to the lowermiddle Miocene; the Globocassidulina spp. Assemblage from the upper lower Miocene to the Pliocene; the Uvigerina proboscidea Assemblage in the upper Miocene and the Pliocene; and the Globocassidulina sp. D Assemblage in the Pliocene. The main faunal change at this site is between the E. umbonifera Assemblage and the Globocassidulina spp. Assemblage, at $~ 17.1 \mathrm{Ma}$. The timing of this faunal change is coeval with faunal changes in the North Atlantic and the Pacific. The change is related to a change in bottom water characteristics caused by an increased influence of carbonate corrosive water from the Antarctic source region, and a change in surface productivity. A low oxygen event at Site 756, which started at about 7.3 Ma, occurred about $2.3 \mathrm{~m} . \mathrm{y}$. before that at Site 754 .

The different response to global paleoceanographic changes is not yet explained, but may be due to the difference of marine topography and the degree of upwelling.
\end{abstract}

\section{INTRODUCTION}

Recent studies in Oligocene and Neogene deep-sea paleoceanography have shown several steps in benthic foraminiferal turnover occurring on a global scale (e.g., Douglas and Woodruff, 1981; Boltovskoy, 1987; Culver, 1987). The tempo and mode of the faunal turnovers and the paleoecological response of benthic foraminifers to oceanographic and climatic changes have been discussed in detail by many workers (e.g., Kennett, 1977; Schnitker, 1980, 1986; Woodruff and Douglas, 1981; Thomas, 1985, 1986a, 1986b; Thomas and Vincent, 1987, 1988). Woodruff (1985) identified a stepwise faunal turnover, related to the development of Antarctic glaciation, as one of the significant foraminiferal events in the Miocene. Species origins and extinctions between 16 and $13 \mathrm{Ma}$ are believed to be related to the expansion of Antarctic glaciation which caused an intensification of atmospheric-ocean circulation and upwelling (Woodruff, 1985). The late Miocene change in species abundance and depth distribution between 10 and $8 \mathrm{Ma}$ is considered to have resulted from an increase of organic carbon, intensification of the low oxygen zones, and an increase in deep ocean dissolution. Other changes in Miocene faunas were caused by an increase of primary produc-

\footnotetext{
${ }^{1}$ Weissel, J., Peirce, J., Taylor, E., Alt, J., et al., 1991. Proc. ODP, Sci. Results, 121: College Station, TX (Ocean Drilling Program).

2 Department of Earth Sciences, Faculty of Education, Shimane University, Matsue 690, Japan.
}

tivity which initiated at 19- 17 Ma (Thomas and Vincent, 1987, 1988; Miller and Katz, 1987).

Despite these discussions, detailed information on the response of faunal change to such paleoceanographic changes in the Indian Ocean is very limited. Most original source data on paleoceanography are from the Atlantic and Pacific Oceans, except for Boltovskoy's work in the Indian Ocean (Boltovskoy, 1977, 1978). Therefore, the purpose of this study is (1) to report species ranges and their quantitative distribution, (2) to distinguish the assemblages based on quantitative analysis, and (3) to clarify the timing and the cause of faunal change in the Indian Ocean and to compare it with equivalent events at other ocean sites.

\section{METHODS}

ODP Site $754\left(30^{\circ} 56.439^{\prime} \mathrm{S} ; 93^{\circ} 33.991^{\prime} \mathrm{E}\right)$ is located on the crest of Broken Ridge and Site $756\left(27^{\circ} 21.330^{\prime} \mathrm{S} ; 87^{\circ} 35.805^{\prime} \mathrm{E}\right)$ is located near the crest of the southern end of Ninetyeast Ridge (Fig. 1). The present water depths are 1074 and $1518 \mathrm{~m}$, respectively. A nearly complete Pleistocene to upper Oligocene section of foraminiferal nannofossil ooze was recovered by the advanced piston corer (APC) at Site 754. Recovery at APC Hole 756B consists of a complete section of lower Oligocene to Pliocene nannofossil ooze containing foraminifers. Cores from Hole $756 \mathrm{C}$ sampled lower Oligocene to upper Eocene nannofossil ooze with foraminifers.

The samples were processed by two methods: loose sediments were washed only, whereas slightly consolidated sediments were treated with a $<3 \%$ hydrogen peroxide solution. In both cases, samples were washed on a $63 \mu \mathrm{m}$ sieve. In order to measure 


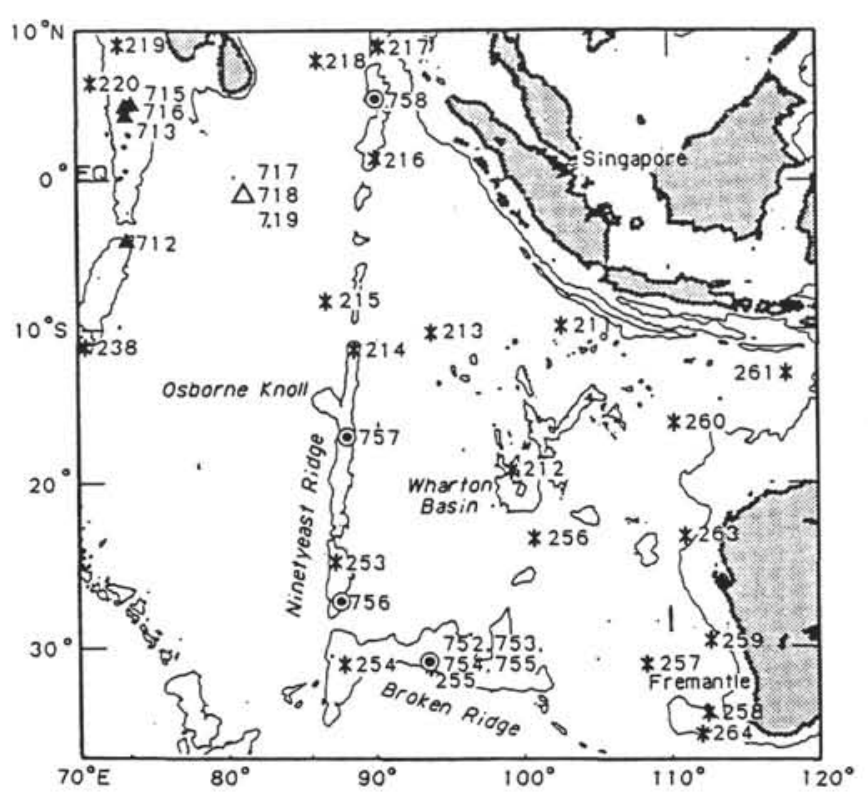

Figure 1.Locations of Site 754 (Broken Ridge) and Site 756 (Ninetyeast Ridge). $*=$ DSDP sites. $\mathbf{\Delta}=$ ODP Leg 115 sites. $\Delta=$ ODP Leg 116 sites. $\bigcirc=$ ODP Leg 121 sites.

sample volume $\left(\mathrm{cm}^{3}\right)$, samples were put into a graduated cylinder with water before washing. Foraminiferal specimens were picked from aliquots of the $>149 \mu \mathrm{m}$ size fraction. This size fraction is the same as that of Miller and Katz (1987). The planktonic to benthic ratio is based on a count of over 100 individuals of both benthic and planktonic foraminifers.

Statistical analysis using a Q-mode factor analysis (CABFAC; Klovan and Imbrie, 1971) was applied to obtain statistically independent assemblages. The selection of species for this analysis was based on the taxa which occurred as $>4 \%$ in each sample, and were found in more than two samples. Age estimation of samples is based on nannofossil biostratigraphy (Peirce, Weissel, et al., 1989). Taxonomy is principally based on Boltovskoy (1977), Corliss (1979b), and van Morkhoven et al. (1986).

\section{RESULTS}

\section{Site $\mathbf{7 5 4}$}

Hole 754A recovered the uppermost Eocene, uppermost Oligocene, and almost complete sections from the lower Miocene to Pleistocene. In this study, 30 samples from the upper Oligocene to the Pleistocene were analyzed for the stratigraphic distribution of benthic foraminifers (Fig. 2; Table 1).

The stratigraphic distribution of the most common species is shown in Figure 3. The species restricted to the uppermost Oligocene to lower Miocene are Bulimina impendens, Uvigerina graciliformis, Pullenia subcarinata, Planulina renzi, and Cibicidoides cf. mundulus. The following species are common to the Oligocene and lower Miocene: Anomalinoides semicribratus, Bulimina tuxpamensis, Rectuvigerina striata, and Nonion havanensis, but they disappear in the planktonic foraminifer N9 Zone. Species that are not present in the upper Miocene, but reported frequently from modern deposits of the Pacific and Atlantic Oceans, are: Burseolina pacifica, Valvulineria laevigata, Astrononion stelligerum, Bulimina rostrata, Trifarina bradyi, Gyroidina lamarckiana, and Uvigerina schencki. Therefore, the composition of deep-sea benthic faunas did not intrinsically change after the late Miocene to the Present as suggested by Berggren and Miller (1989).
Relative abundance of the main species is plotted against sub-bottom depths and nannofossil zones in Figure 4. Globocassidulina spp., comprising smaller-sized G. globosa, is characteristically abundant in the Oligocene (up to $27 \%$ of the fauna). Globocassidulina subglobosa, with a larger test, is abundant in the upper Miocene and the Pleistocene. Owing to external similarity of these species, except for the test size, both are assigned to one group in this study. Lenticulina spp. are abundant in the lower Miocene, but decrease in relative abundance upward from the middle Miocene. A similar trend is observed in Sphaeroidina bulloides. Cibicidoides mundulus occurs commonly in the lower Miocene, though its peak relative abundance is found in the upper middle Miocene to upper Miocene. Burseolina pacifica and B. cf. pacifica are commonly found through the lower and middle Miocene, but $B$. cf. pacifica rapidly decreases in relative abundance within the lower middle Miocene (Samples 121-754A-8H-5, 70$75 \mathrm{~cm}$, to $-8 \mathrm{H}-1,70-75 \mathrm{~cm}$ ). Uvigerina proboscidea frequently occurs through the Miocene and dominates in the upper Pliocene. Bulimina mexicana occurs commonly in the upper Miocene and Pliocene, but its relative abundance is much reduced from in the uppermost Miocene and lower Pliocene. Planulina wuellerstorfi has a first appearance in the upper Miocene (nannofossil Zone $\mathrm{CN} 4)$ and increases rapidly in relative abundance in the middle Miocene to $18 \%$, with the highest peak abundance (26\%) found in the nannofossil Zone CN9b-10a of the late Miocene. Karreriella bradyi occurs continuously at Site 754 and its relative abundance tends to increase from the middle Miocene to Pleistocene, but it is rare in the Pleistocene. The following species do not have continuous stratigraphic occurrences, but are prominent members of the fauna: Ehrenbergina carinata and $E$. spp. in the Pleistocene (up to $38 \%$ ) and Gavelinopsis lobatulus and Astrononion echolsi in the Pliocene (up to $25 \%$ ) and the uppermost middle Miocene (up to $11 \%$ ).

Species diversity calculated by the Shannon-Wiener Information Function $\left(\mathrm{H}^{\prime}\right)$ reveals three stages (Fig. 5). The diversity of the lower Miocene assemblage is in the range of 4.5-5.0 (average 4.81). A characteristic drop in diversity is found in the lowermost middle Miocene assemblage between Samples 121-754A-9H-1, $70-75 \mathrm{~cm}$, and $-8 \mathrm{H}-5,70-75 \mathrm{~cm}$. Most samples from the middle Miocene and upper Miocene to Pliocene show diversities of $4.0-4.5$ (average 4.26 ). Lower diversity $(<4.0)$ is observed in Oligocene and Pleistocene samples. The samples show a rapid decrease in diversity from the upper Pliocene to the Pleistocene at this site and the diversity in the Pleistocene is particularly low.

\section{Site $\mathbf{7 5 6}$}

Holes $756 \mathrm{~B}$ and $756 \mathrm{C}$ recovered almost complete sections of the Oligocene to Pliocene. Forty-four samples were analyzed for the species range and frequency distribution (Fig. 2; Table 2).

Stratigraphic distribution of the most common species is shown in Figure 6. The stratigraphic ranges of some species are compared with the range reported by van Morkhoven et al. (1986) and Berggren and Miller (1989). Cibicidoides laurisae is known up to P22, but it disappeared in Zone CP17 (P18) at this site. Three species, Uvigerina spinulosa, Cibicidoides mexicanus, and $\mathrm{Bu}$ limina impendens, are known to disappear in N5 (van Morkhoven et al., 1986). At Site 756, Uvigerina spinulosa is rare and ranges only through Zone CP18 (or P18-19). Cibicidoides mexicanus and B. impendens occur up to Zone CN1 (N4) at this site. Anomalinoides pseudogrosserugosus, Cibicidoides alazanensis, Siphonina tenuicarinata, and Bulimina tuxpamensis have been recorded up to N9, whereas A.pseudogrosserugosus occurs from CP16-18 (or P16-P18/19). Cibicidoides alazanensis and S. tenuicarinata disappeared in Zone $\mathrm{CN} 3 / 4$, which is similar to its range as reported by van Morkhoven et al.(1986). Bulimina jarvisi, with its last appearance in $\mathrm{N} 10$, is restricted to the upper Oligocene to 

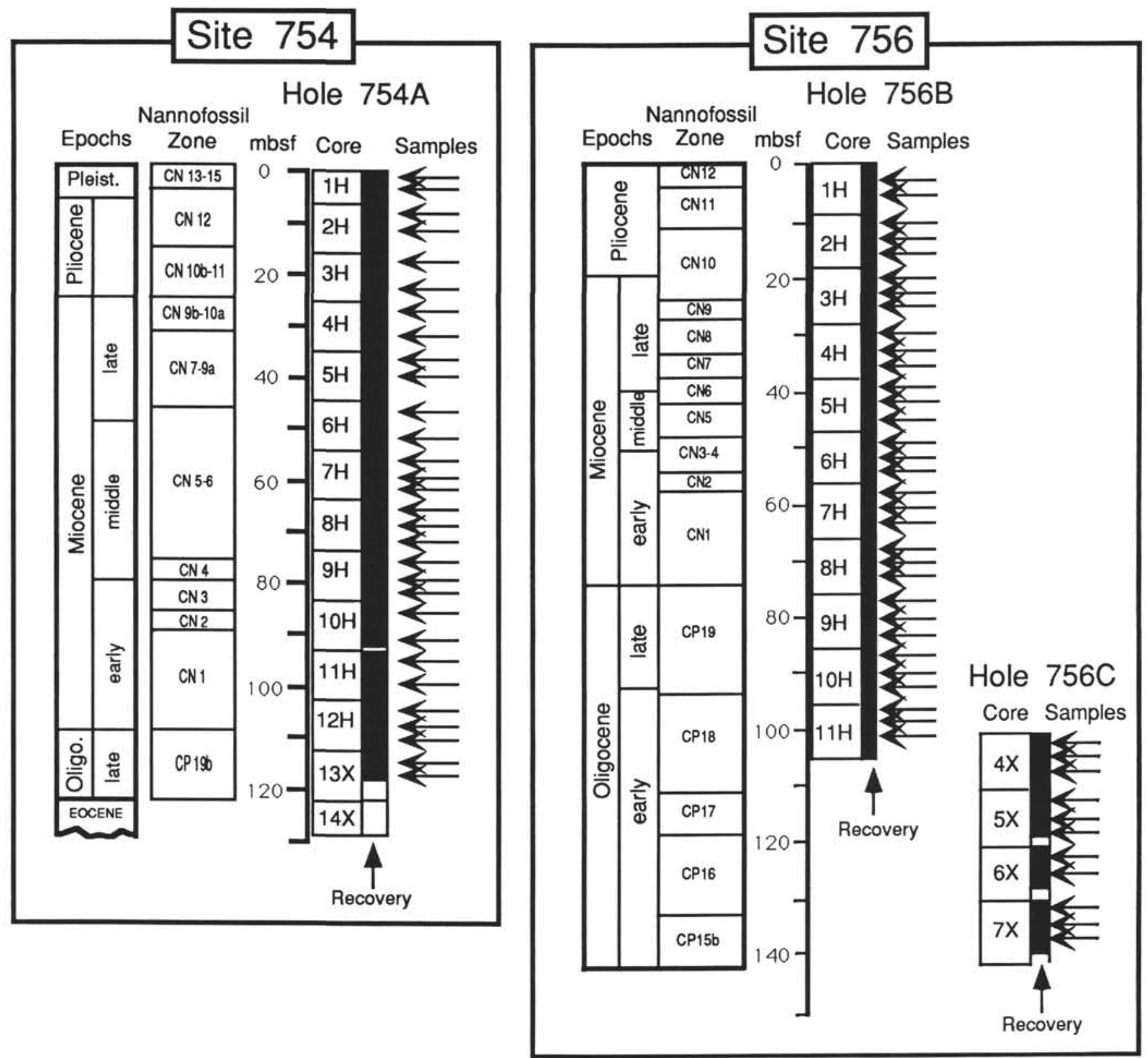

Figure 2. Samples analyzed in this study.

lowermost Miocene (CP9-CN1 or P21-N4) at this site. Hanzawaia ammophila ranges from lower Eocene to Miocene (P6a-N11), but is found only in the lower Oligocene at Site 756. The limited occurrence of $H$. ammophila at this site may be related to the rifting event of Broken Ridge. According to van Morkhoven et al. (1986), H. ammophila has its optimum occurrence in outer neritic to upper bathyal environments. Anomalinoides semicribratus, with known ranges from $\mathrm{P} 12$ to N12, disappears in Zone $\mathrm{CN} 3 / 4$ (or P10-13) at this site. Planulina renzi is known to occur in the range of $\mathrm{P} 16 / 17-\mathrm{N} 17$, but it ranges from the Oligocene to the lower Miocene (CP17-CN2 or P18-N4) at Site 756.

Anomalinoides globulosus first appears in Zone CN6 or Zone $\mathrm{N} 15$, consistent with the known first appearance of this species (van Morkhoven et al., 1986). Planulina wuellerstorfi, with its first appearance in Zone N9, occurs at Site 756 in the lower middle Miocene (CN3/4 or N10-13), suggesting almost coeval appearance with its known first appearance (van Morkhoven et al., 1986;
Miller and Katz, 1987; Thomas and Vincent, 1987). Uvigerina hispida is recorded from the early Miocene to Pleistocene (van Morkhoven et al., 1986), though it appears from the Pliocene at Site 756.

The relative abundances of the most common species are plotted vs. sub-bottom depths and nannofossil zones in Figure 7. Globocassidulina spp., consisting of G. subglobosa and G. globosa, are abundant and occur almost continuously at this site, with wide fluctuations of abundance. A marked change in abundance of this taxon occurs within the middle Miocene, where its relative abundance falls rapidly from $18 \%$ (Sample 121-756B-6H-3, 70$75 \mathrm{~cm}$ ) to $1 \%$ (Sample 121-756B-6H-1, 70-75 cm). Cibicidoides cf. mundulus, characterized by a small and thin-shaped test, dominates in the lower Oligocene. Instead of $C$. cf. mundulus, Cibicidoides mundulus is abundant from the upper Oligocene. Epistominella umbonifera is abundant in the Oligocene, making up to $21 \%$ of the fauna. Astrononion echolsi is common through 
Table 1. Occurrence of benthic foraminifers at Site 754.

\begin{tabular}{|c|c|c|c|c|c|c|c|c|c|c|c|c|c|}
\hline Hole & $754 \mathrm{~A}$ - & & & & & & & & & & & & \\
\hline Sections & $1 \mathrm{H}-1$ & $1 \mathrm{H}-3$ & $2 \mathrm{H}-1$ & $2 \mathrm{H}-3$ & $3 \mathrm{H}-1$ & $3 \mathrm{H} \cdot 5$ & $4 \mathrm{H}-1$ & $4 \mathrm{H}-5$ & $5 \mathrm{H}-1$ & $5 \mathrm{H} \cdot 5$ & $6 \mathrm{H}-1$ & $6 \mathrm{H} \cdot 5$ & $7 \mathrm{H}-1$ \\
\hline Intervals $(\mathrm{cm})$ & $70-75$ & $70-75$ & $70-75$ & $70-75$ & $70-75$ & $70-75$ & $70-75$ & $70-75$ & 70.75 & 70.75 & $70-75$ & $70-75$ & $70-75$ \\
\hline $\begin{array}{l}\text { Amphicoryna scalaris } \\
\text { Anomalinoides flintii } \\
\text { Anomalinoides globulosus } \\
\text { Anomalinoides semicribratus } \\
\text { Anomalinoides sp. A } \\
\end{array}$ & & 2 & & 5 & $\begin{array}{l}2 \\
8 \\
\end{array}$ & & & & & 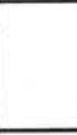 & 1 & 1 & \\
\hline \begin{tabular}{|l} 
Astrononion echolsi \\
Astrononion ct. echolsi \\
Astrononion stelligerum \\
Astrononion sp. indet. \\
Bolivina pseudoplicata \\
\end{tabular} & & & 8 & 20 & 8 & 9 & 1 & 1 & $\begin{array}{l}1 \\
1\end{array}$ & 3 & 1 & & \\
\hline \begin{tabular}{|l} 
Bolivinopsis cubensis \\
Brizalina albatrossi \\
Brizalina cf. pacilica \\
Brizalina petterssoni \\
Brizalina silvestriana \\
\end{tabular} & & & 7 & & 1 & & $\begin{array}{l}5 \\
2\end{array}$ & 2 & 16 & 6 & 16 & 10 & 2 \\
\hline \begin{tabular}{|l} 
Brizalina sp. \\
Bulimina ct. thalmanni \\
Bulimina impenedens \\
Bulimina mexicana \\
Bulimina ct.mexicana \\
\end{tabular} & & 1 & & 22 & 2 & 2 & 2 & & & 24 & 3 & 10 & \\
\hline $\begin{array}{l}\text { Bulimina rostrata } \\
\text { Bulimina tuxpamensis } \\
\text { Bulimina cf. tuxpamensis } \\
\text { Bulimina sp. } \\
\text { Bulimina sp. indet. } \\
\end{array}$ & & & & & & & & & 1 & & & 1 & $\begin{array}{l}7 \\
1\end{array}$ \\
\hline $\begin{array}{l}\text { Burseolina pacifica } \\
\text { Burseolina ct. pacifica } \\
\text { Burseolina sp. A } \\
\text { Cibicides? sp. } \\
\text { Cibicides lobatulus } \\
\end{array}$ & 1 & 9 & & & 1 & 3 & $\begin{array}{l}1 \\
2 \\
\end{array}$ & 9 & 26 & 16 & $\begin{array}{l}2 \\
9 \\
\end{array}$ & 8 & 21 \\
\hline \begin{tabular}{|l|} 
Cibicidoides dutemplei \\
Cibicidoides grosseperforatus \\
Cibicidoides herricki \\
Cibicidoides mundulus \\
Cibicidoides ct. mundulus \\
\end{tabular} & 11 & 4 & 1 & 7 & 16 & 19 & 3 & 5 & & 2 & 19 & 9 & 11 \\
\hline $\begin{array}{l}\text { Cibicidoides pachydema } \\
\text { Cibicidoides robertsonianus } \\
\text { Cibicidoides spp. } \\
\text { Dentalina communis } \\
\text { Dentalina hircicornua } \\
\end{array}$ & 2 & 2 & 21 & 7 & 0 & 4 & 4 & & 1 & 3 & 1 & 1 & $\begin{array}{l}3 \\
1\end{array}$ \\
\hline \begin{tabular}{|l|} 
Dentalina ct. hircicornua \\
Dentalina intorta \\
Dentalina sp. A \\
Dentalina spp. \\
Dyocibicides spp. \\
\end{tabular} & 1 & & & 6 & $\begin{array}{l}1 \\
1\end{array}$ & & 2 & & $\begin{array}{l}1 \\
1\end{array}$ & & & & 1 \\
\hline $\begin{array}{l}\text { Eggerella bradyi } \\
\text { Eggerella sp. } \\
\text { Ehrenbergina carinata } \\
\text { Ehrenbergina spp. } \\
\text { Epistominella exigua }\end{array}$ & 22 & 47 & 1 & 1 & & 24 & 11 & $\begin{array}{l}11 \\
1 \\
\end{array}$ & & & & & \\
\hline $\begin{array}{l}\text { Epistominella umbomilera } \\
\text { Epistominella ct. umbomifera } \\
\text { Epistominella sp. A } \\
\text { Fissurina spp. } \\
\text { Fursenkoina squammosa } \\
\end{array}$ & 4 & 2 & 7 & $\begin{array}{l}7 \\
3 \\
\end{array}$ & 5 & $\begin{array}{l}5 \\
1 \\
\end{array}$ & 3 & 2 & & 2 & $\begin{array}{l}2 \\
3\end{array}$ & & $\begin{array}{l}2 \\
2\end{array}$ \\
\hline $\begin{array}{l}\text { Fursenkoina sp. B } \\
\text { Fursenkoina spp. } \\
\text { Gauduryina spp. } \\
\text { Gavelinopsis lobatulus } \\
\text { Globobulimina spp. } \\
\end{array}$ & 1 & & $\begin{array}{c}1 \\
24\end{array}$ & 16 & $\begin{array}{c}9 \\
54\end{array}$ & 2 & $\begin{array}{l}1 \\
4 \\
1\end{array}$ & 9 & 2 & & 29 & 1 & 1 \\
\hline $\begin{array}{l}\text { Globocassidulina alternans } \\
\text { Globocassidulina crassa } \\
\text { Globocassidulina decorata } \\
\text { Globocassidulina havanensis } \\
\text { Globocassidulina cl. havanensis }\end{array}$ & & & 1 & 6 & 15 & 2 & & 2 & & 6 & 4 & & $\begin{array}{l}1 \\
5\end{array}$ \\
\hline $\begin{array}{l}\text { Globocassidulina reflexa } \\
\text { Globocassidulina sp. B } \\
\text { Globocassidulina sp.E } \\
\text { Globocassidulina spp. } \\
\text { Globocassidulina sp. indet. }\end{array}$ & 77 & 2 & 13 & $\begin{array}{l}1 \\
1\end{array}$ & $\begin{array}{c}9 \\
11 \\
1 \\
\end{array}$ & 16 & 45 & $\begin{array}{c}1 \\
42\end{array}$ & 21 & 50 & 39 & 6 & 7 \\
\hline \begin{tabular}{|l|} 
Guttulina spp. \\
Gyroidina laevigata \\
Gyroidina lamarckiana \\
Gyroidina ct.lamarckiana \\
Gyroidina orbicularis \\
\end{tabular} & 1 & & 3 & 4 & 1 & & $\begin{array}{l}1 \\
2 \\
\end{array}$ & 2 & 2 & $\begin{array}{c}6 \\
12 \\
\end{array}$ & $\begin{array}{l}2 \\
2 \\
\end{array}$ & & $\begin{array}{l}1 \\
2 \\
\end{array}$ \\
\hline $\begin{array}{l}\text { Gyroidina soldanii } \\
\text { Heronarellina sp. "A* } \\
\text { Karreriella bradyi } \\
\text { Kyphopyxa sp. A } \\
\text { Lagena spp. } \\
\end{array}$ & $\begin{array}{l}3 \\
4 \\
\end{array}$ & 1 & $\begin{array}{c}1 \\
13 \\
4\end{array}$ & $\begin{array}{l}20 \\
2\end{array}$ & $\begin{array}{l}2 \\
2 \\
2\end{array}$ & $\begin{array}{l}6 \\
23 \\
4\end{array}$ & $\begin{array}{l}11 \\
15 \\
2\end{array}$ & $\begin{array}{c}12 \\
1 \\
\end{array}$ & $\begin{array}{l}13 \\
16 \\
1 \\
\end{array}$ & $\begin{array}{l}9 \\
5 \\
\end{array}$ & $\begin{array}{c}3 \\
1 \\
15 \\
3 \\
\end{array}$ & $\begin{array}{l}6 \\
1 \\
4\end{array}$ & $\begin{array}{l}7 \\
3 \\
\end{array}$ \\
\hline $\begin{array}{l}\text { Laticarinina pauperata } \\
\text { Lenticulina spp. } \\
\text { Marginulina sp. } 2\end{array}$ & & 5 & 10 & 2 & $\begin{array}{l}6 \\
1\end{array}$ & $\begin{array}{l}7 \\
2\end{array}$ & $\begin{array}{c}15 \\
1\end{array}$ & $\begin{array}{l}9 \\
4\end{array}$ & & $\begin{array}{l}4 \\
1\end{array}$ & $\begin{array}{l}1 \\
1\end{array}$ & $\begin{array}{l}7 \\
1\end{array}$ & $\begin{array}{l}5 \\
2\end{array}$ \\
\hline
\end{tabular}


Table 1 (continued).

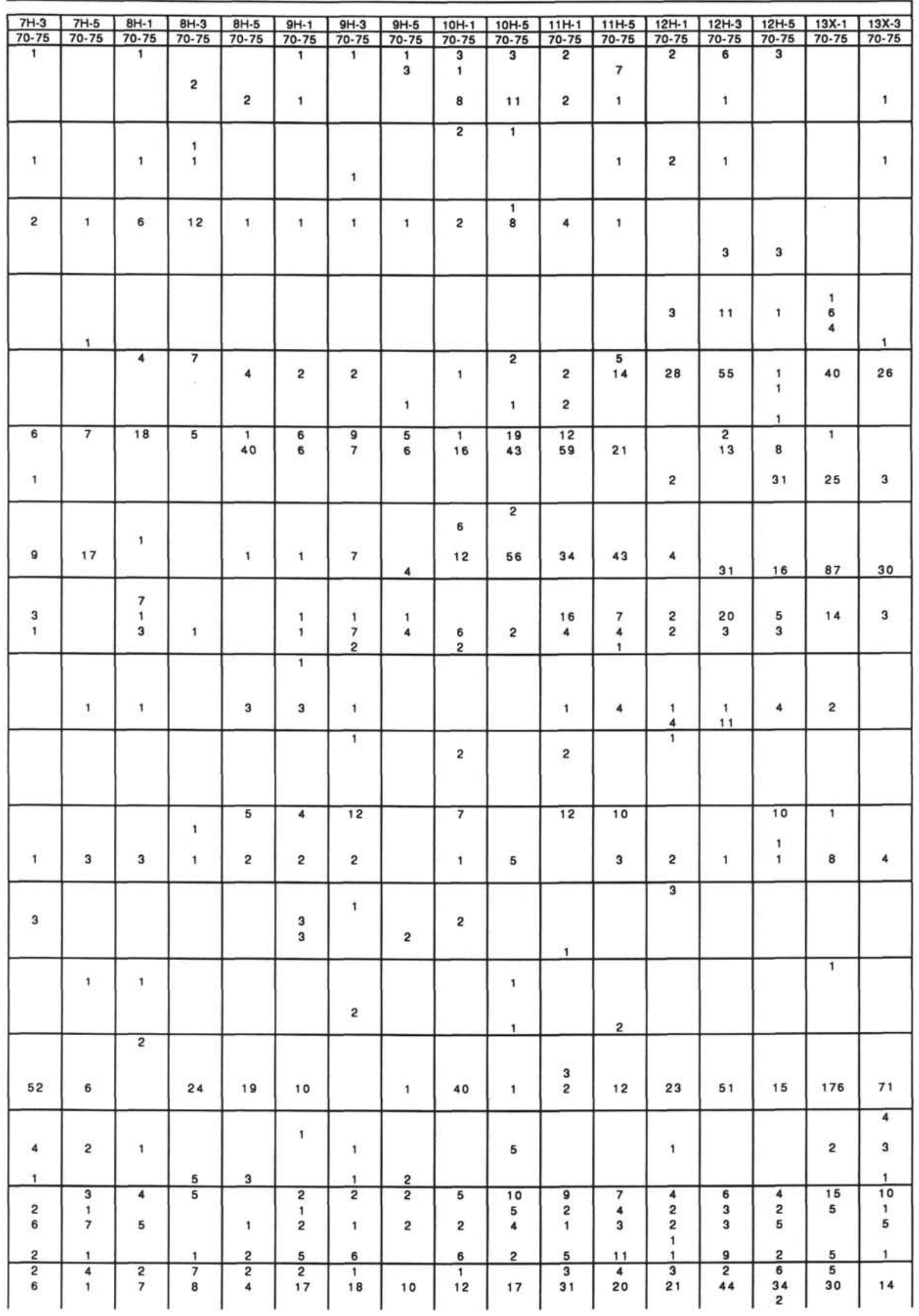


Table 1 (continued).

\begin{tabular}{|c|c|c|c|c|c|c|c|c|c|c|c|c|c|}
\hline Hole & $754 \mathrm{~A}$. & & & & & & & & & & & & \\
\hline Sections & $1 \mathrm{H}-1$ & $1 \mathrm{H} \cdot 3$ & $2 \mathrm{H}-1$ & $2 \mathrm{H}-3$ & $3 \mathrm{H}-1$ & $3 \mathrm{H} \cdot 5$ & $4 \mathrm{H} \cdot 1$ & $4 \mathrm{H}-5$ & \begin{tabular}{|c|}
$\mathrm{H}-1$ \\
\end{tabular} & $5 \mathrm{H}-5$ & $6 \mathrm{H}-1$ & $6 \mathrm{H} \cdot 5$ & $7 \mathrm{H}-1$ \\
\hline Intervals $(\mathrm{cm})$ & 70.75 & $70 \cdot 75$ & 70.75 & 70.75 & $70-75$ & $70-75$ & $70-75$ & $70-75$ & 70.75 & $70 \cdot 75$ & $70 \cdot 75$ & 70.75 & 70.75 \\
\hline $\begin{array}{l}\text { Marginulina sp. A } \\
\text { Marginulina sp. B }\end{array}$ & & & & & & & & & 1 & & $\mathrm{I}$ & & \\
\hline $\begin{array}{l}\text { Marginulina spp. } \\
\text { Marginulinopsis spp. } \\
\text { Martinottiella scabra } \\
\text { Neoconorbina sp. A } \\
\text { Nodoraria pyrula }\end{array}$ & & & 2 & & 1 & & & 2 & & 4 & & & 1 \\
\hline $\begin{array}{l}\text { Nodosaria ct. pyrula } \\
\text { Nodosaria spp. } \\
\text { Nodosaria sp. indet. } \\
\text { Nodosariella pacifica } \\
\text { Nodosariella spp. } \\
\end{array}$ & & & & & & 3 & & & & 1 & 1 & & 1 \\
\hline $\begin{array}{l}\text { Nonion affine } \\
\text { Nonion havanensis } \\
\text { Nonion spp. } \\
\text { Oolina spp. } \\
\text { Ophtharnidium sp. }\end{array}$ & $\begin{array}{l}1 \\
1\end{array}$ & 3 & $\begin{array}{l}1 \\
3\end{array}$ & $\begin{array}{l}2 \\
1\end{array}$ & 2 & 2 & $\begin{array}{l}4 \\
4\end{array}$ & 2 & 1 & 3 & 2 & 1 & 1 \\
\hline $\begin{array}{l}\text { Oridorsalis umbonatus } \\
\text { Orthomorphina antillea } \\
\text { Onthomorphina ct. antillea } \\
\text { Orthomorphina challengeriana } \\
\text { Orthomorphina columnaris } \\
\end{array}$ & 11 & $\begin{array}{l}1 \\
1\end{array}$ & 5 & $\begin{array}{c}10 \\
2\end{array}$ & 9 & $\begin{array}{l}12 \\
5\end{array}$ & $\begin{array}{l}15 \\
1 \\
\end{array}$ & $\begin{array}{c}3 \\
10 \\
8 \\
1\end{array}$ & $\begin{array}{l}17 \\
5 \\
1\end{array}$ & $\begin{array}{l}11 \\
1 \\
1 \\
\end{array}$ & 16 & $\begin{array}{l}3 \\
1 \\
2\end{array}$ & 5 \\
\hline $\begin{array}{l}\text { Orthomorphina glandigena } \\
\text { Orthomorphina himerensis } \\
\text { Orthomorphina modesta } \\
\text { Orthomorphina richardsi } \\
\text { Orthomorphina spp. }\end{array}$ & & $\begin{array}{l}1 \\
1\end{array}$ & $\begin{array}{l}1 \\
2 \\
2\end{array}$ & 4 & $\begin{array}{l}3 \\
1\end{array}$ & 2 & 2 & 3 & 1 & $\begin{array}{c}2 \\
14\end{array}$ & & 3 & \\
\hline $\begin{array}{l}\text { Osangularia mexicana } \\
\text { Paracassidulina minuta } \\
\text { Paracassidulina neocarinata } \\
\text { Paracassidulina sulcata } \\
\text { Paracassidulina spp. }\end{array}$ & 9 & 12 & 1 & 1 & & & & & & 3 & & & 1 \\
\hline $\begin{array}{l}\text { Parafissurina spp. } \\
\text { Planulina costata } \\
\text { Planulina renzi } \\
\text { Planulina wuellerstorti } \\
\text { Plectirondicularia spp. }\end{array}$ & 22 & 3 & 10 & 4 & & 21 & 69 & 6 & 1 & 1 & & $\begin{array}{l}1 \\
14\end{array}$ & 11 \\
\hline $\begin{array}{l}\text { Pleurostomella acuminata } \\
\text { Pleurostomella acuta } \\
\text { Pleurostomella alternans } \\
\text { Pleurostomella bierigi } \\
\text { Pleurostomella sp. A }\end{array}$ & & & $\begin{array}{l}2 \\
4\end{array}$ & 4 & & 1 & 1 & 1 & $\begin{array}{l}1 \\
2\end{array}$ & 6 & 5 & $\begin{array}{l}1 \\
1\end{array}$ & \\
\hline $\begin{array}{l}\text { Pleurostomella sp. B } \\
\text { Pleurostomella spp. } \\
\text { Pleurostomella sp. indet. } \\
\text { Pseudonodosaria laevigata } \\
\text { Pseudonodosaria sp. A }\end{array}$ & & 1 & & & & & & 2 & & & & 1 & \\
\hline $\begin{array}{l}\text { Pullenia bulloides } \\
\text { Pullenia osloensis } \\
\text { Pullenia quinqueloba } \\
\text { Pullenia subcarinata } \\
\text { Pullenia cf. subcarinata } \\
\end{array}$ & 1 & $\begin{array}{l}1 \\
1\end{array}$ & & $\begin{array}{l}4 \\
1\end{array}$ & $\begin{array}{c}16 \\
1 \\
1\end{array}$ & $\begin{array}{l}7 \\
1 \\
3\end{array}$ & $\begin{array}{l}3 \\
7 \\
2\end{array}$ & $\begin{array}{c}18 \\
4 \\
2\end{array}$ & $\begin{array}{c}13 \\
4\end{array}$ & 3 & $\begin{array}{l}1 \\
1 \\
8\end{array}$ & $\begin{array}{l}11 \\
4\end{array}$ & $\begin{array}{c}10 \\
5 \\
3\end{array}$ \\
\hline $\begin{array}{l}\text { Quinqueloculina sp. } \\
\text { Ramulina globulifera } \\
\text { Rectuvigerina striata } \\
\text { Rectuvigerina sp. A } \\
\text { Saracenaria latifrons }\end{array}$ & 5 & 2 & 3 & & 3 & & 1 & 1 & & & & 2 & 1 \\
\hline $\begin{array}{l}\text { Saracenaria latifrons jamaicensis } \\
\text { Saracenaria spp. } \\
\text { Siphonina pozonensis } \\
\text { Sphaeroidina bulloides } \\
\text { Sphaeroidina c1. bulloides }\end{array}$ & & 1 & & 1 & 4 & & 2 & 1 & 1 & & & & \\
\hline $\begin{array}{l}\text { Spiroplectammina sp. A } \\
\text { Spiroplectammina spp. } \\
\text { Stilostomella aculeata } \\
\text { Stilostomella annulifera } \\
\text { Stilostomella ct. annulifera }\end{array}$ & 1 & 1 & 1 & 7 & 2 & & & & $\begin{array}{c}1 \\
16\end{array}$ & 3 & 5 & 1 & 11 \\
\hline $\begin{array}{l}\text { Stilostomella lepidula } \\
\text { Stilostomella subspinosa } \\
\text { Textularia Ilintii } \\
\text { Textularia halkyardi } \\
\text { Textularia milletti }\end{array}$ & 2 & $\begin{array}{l}2 \\
1\end{array}$ & 4 & 5 & 3 & 2 & 2 & 1 & & $\begin{array}{l}3 \\
2\end{array}$ & 3 & 10 & \\
\hline $\begin{array}{l}\text { Textularia sp. A } \\
\text { Textularia spp. } \\
\text { Trifarina bradyi } \\
\text { Tritarina sp. A } \\
\text { Trifarina sp. }\end{array}$ & 1 & & 1 & & & & & & 1 & & & 1 & \\
\hline $\begin{array}{l}\text { Uvigerina graciliformis } \\
\text { Uvigerina hispidula } \\
\text { Uvigerina mexicana } \\
\text { Uvigerina miozea } \\
\text { Uvigerina peregrina }\end{array}$ & 3 & 1 & 2 & & 2 & & & 3 & & 6 & & & \\
\hline
\end{tabular}


Table 1 (continued).

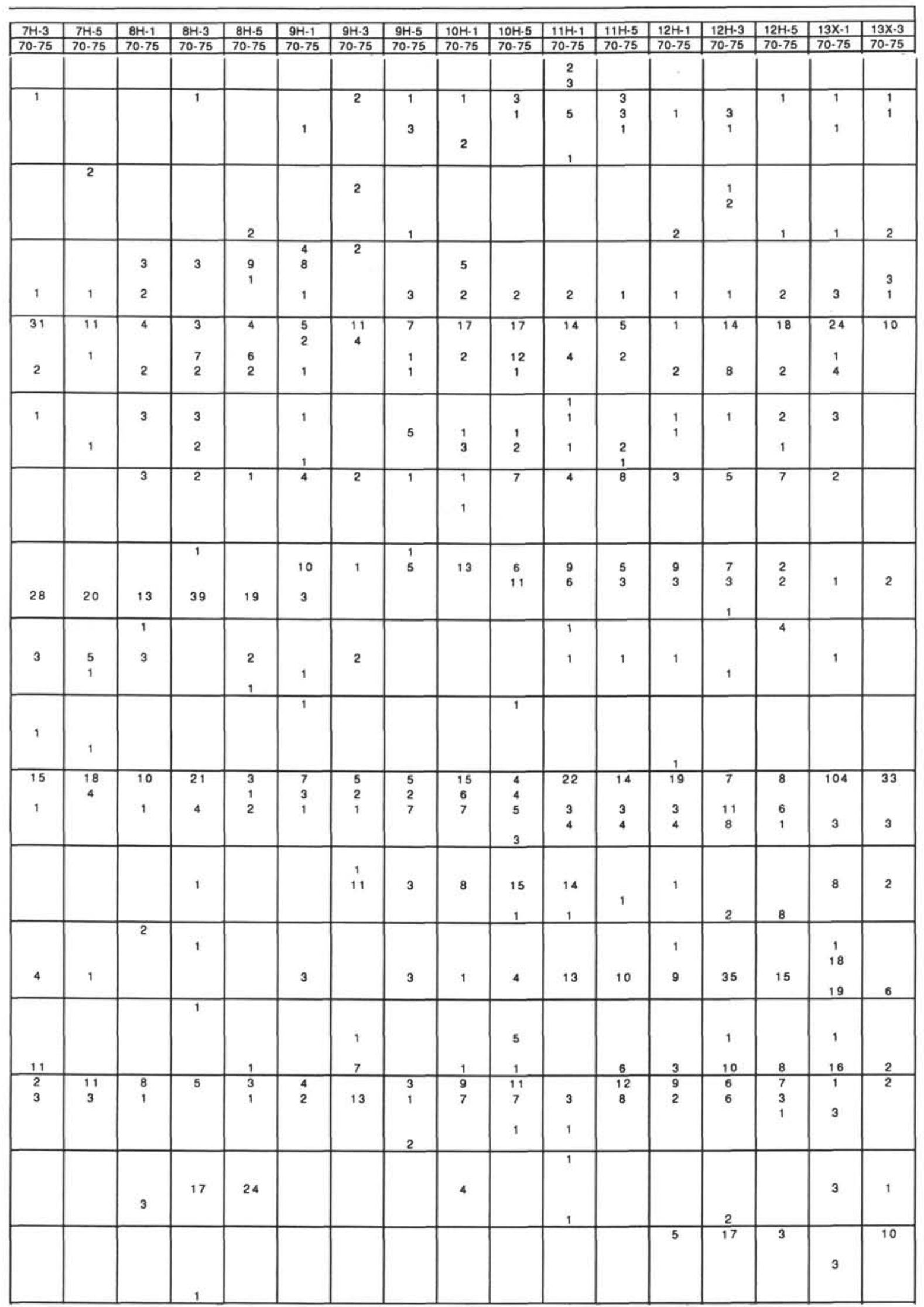


Table 1 (continued).

\begin{tabular}{|c|c|c|c|c|c|c|c|c|c|c|c|c|c|}
\hline Hole & $754 A$. & & & & & & & & & & & & \\
\hline Sections & $1 \mathrm{H}-1$ & $1 \mathrm{H} \cdot 3$ & $2 \mathrm{H}-1$ & $2 \mathrm{H}-3$ & $3 \mathrm{H}=1$ & $3 \mathrm{H}-5$ & $4 \mathrm{H}-1$ & $4 \mathrm{H} \cdot 5$ & $5 \mathrm{H}-1$ & $5 \mathrm{H} .5$ & $6 \mathrm{H}-1$ & $6 \mathrm{H} \cdot 5$ & $7 \mathrm{H} \cdot 1$ \\
\hline Intervals (cm) & 70.75 & 70.75 & 70.75 & $70-75$ & 70.75 & $70 \cdot 75$ & 70.75 & 70.75 & 70.75 & $70-75$ & $70-75$ & $70-75$ & $70-75$ \\
\hline $\begin{array}{l}\text { Uvigerina proboscidea } \\
\text { Uvigerina schencki } \\
\text { Uvigerina sp. A } \\
\text { Uvigerina spp. }\end{array}$ & & 1 & 42 & 1 & 5 & 2 & $\begin{array}{l}8 \\
5\end{array}$ & $\begin{array}{l}5 \\
2\end{array}$ & $\begin{array}{c}4 \\
12\end{array}$ & 12 & $\begin{array}{l}3 \\
1\end{array}$ & 10 & 1 \\
\hline Uvigerina striatula & & & 2 & & & & & & & & & & \\
\hline $\begin{array}{l}\text { Vaginulina legumen } \\
\text { Vaginulina spp. } \\
\text { Valvulina spinosa } \\
\text { Valvulineria spp. } \\
\text { Valvulineria laevigata }\end{array}$ & & & 1 & & & & 1 & & & 1 & & & 1 \\
\hline Agglutinated misc. & & & & & & 1 & & & & & & 1 & \\
\hline Calcareous misc. & 2 & 3 & & 4 & 2 & 2 & 2 & 1 & 1 & 2 & 1 & & 1 \\
\hline Total number of specimens & 186 & 121 & 209 & 184 & 214 & 201 & 264 & 190 & 187 & 228 & 204 & 136 & 139 \\
\hline
\end{tabular}

the Oligocene and upper Pliocene, but is almost absent in the Miocene. Burseolina pacifica is at its peak abundance $(15 \%)$ in the earliest middle Miocene (CN3/4). Lenticulina spp. are common in the Oligocene and lower Miocene, but decrease in abundance after the middle Miocene, as reported by Woodruff and Douglas (1981). Uvigerina proboscidea is common in the upper Miocene and Pliocene, forming 22\% (Sample 121-756B-2H-3, $70-75 \mathrm{~cm})$ of the assemblage in the lower Pliocene $(\mathrm{CN} 10)$.

Species diversity $\left(\mathrm{H}^{\prime}\right)$ at Site 756 is generally constant and in the range of 4.0-5.0, except for the upper middle Miocene (Samples 121-756B-5H-3, 70-75 cm, and -5H-4, 70-75 cm) and upper Pliocene (Samples 121-756B-1H-3, 70-75 cm), which show the lowest values of diversity $(<4.0)$ for this site (Fig. 8 ).

A change of planktonic percentage is found between Samples $121-756 \mathrm{~B}-8 \mathrm{H}-3,70-75 \mathrm{~cm}$, and $-8 \mathrm{H}-5,70-75 \mathrm{~cm}$ (Fig. 8). The planktonic percentage in the Oligocene averages $93.3 \%$, but varies widely. The Neogene planktonic percentage, however, is higher than that of the Oligocene ( $>98 \%$ ) (Fig. 8). If the sedimentation rate is assumed constant, the numbers of benthic foraminifers $/ \mathrm{cm}^{3}$ are reduced throughout the middle Miocene (Fig. 8).

\section{Comparison between Site $\mathbf{7 5 4}$ and Site $\mathbf{7 5 6}$}

Site 754 and Site 756 are situated in the same water mass, i.e., the Indian Central Water (Sverdrup et al., 1942), and both are situated at bathyal depths, but some differences in the composition and frequency of the most common species are clear within the Neogene. Globocassidulina spp. characteristically dominated the fauna at both sites, and the occurrence pattern during the Neogene is more or less similar at both sites. The relative abundance of Globocassidulina spp., however, in the upper Pliocene (CN12 Zone) at Site 754 is much lower than that at Site 756. Cibicidoides mundulus dominated the fauna after the early Miocene at Site 754, whereas at Site 756 C. mundulus became dominant in the late Oligocene and earliest Miocene. Cibicidoides $\mathrm{cf}$. mundulus was abundant at Site 754 in the late Oligocene and earliest Miocene. At Site 756, C. cf. mundulus dominated in the early Oligocene. Astrononion echolsi was common in the Oligocene and the Neogene; its peak abundance was in the Pliocene at Site 754 and the early Oligocene at Site 756.

The following Neogene species, recognized as the most common elements at Site 754, are less important at Site 756: Karreriella bradyi, Gyroidina orbicularis, Burseolina cf. pacifica, Trifarina bradyi, Sphaeroidina bulloides, Rectuvigerina striata, Gavelinopsis lobatulus, Ehrenbergina carinata, Bulimina tuxpamensis, Bulimina mexicana, Pullenia bulloides, and Planulina wuellerstorfi. On the contrary, the following species are important at Site 756, but they are not abundant at Site 754: Stilostomella lepidula, Orthomorphina antillea, Oridorsalis umbonatus, Gyroidina soldanii, Globocassidulina sp. D., and Epistominella umbonifera.
The following species show a similar occurrence through the Neogene at both sites: Lenticulina spp., Burseolina pacifica, and Uvigerina proboscidea.

\section{FAUNAL ANALYSIS}

\section{Site $\mathbf{7 5 4}$}

The result of a factor analysis with a varimax rotation shows that the first seven factors account for $79 \%$ of the faunal variation of the Site 754 data set (Tables 3,4). The stratigraphic distribution of the factor loading for each factor is shown in Figure 9.

Globocassidulina spp. Varimax Assemblage (Factor 1; $20.95 \%$ of the total variance) is well developed in the Neogene. Factor loadings higher than average $(0.35)$ occur in the Oligocene (CP19; Sample 121-754A-13X-3, 70-75 cm), lower Miocene (CN3; Sample 121-754A-10H-1, 70-75 cm), middle Miocene (CN5-6, Sample 121-754A-7H-3, 70-75 cm), upper Miocene (CN7-CN10b/11, Sections 121-754A-3H-5 to $-6 \mathrm{H}-1 ; 26-45.2$ mbsf), and uppermost Pleistocene (CN13-15, Sample 121-754A$1 \mathrm{H}-1,70-75 \mathrm{~cm})$. This assemblage is dominated by Globocassidulina subglobosa and $G$. globosa.

Burseolina cf. pacifica-Cibicidoides mundulus Varimax Assemblage (Factor 2; $12.06 \%$ of the total variance) is distributed in the middle lower Miocene. This assemblage was typically found at 89.9-99.6 mbsf (from Sections 121-754A-10H-5 to -11H-5).

Planulina wuellerstorfi Varimax Assemblage (Factor 3; $14.39 \%$ of the total variance) is mainly found in the middle Miocene (51.2-67.5 mbsf). A smaller loading peak appears in the uppermost Miocene (Sample 121-754A-4H-1, 70-75 cm; 26 mbsf). Pullenia bulloides and Burseolina pacifica are included in this assemblage.

Gavelinopsis lobatulus-Uvigerina proboscidea Varimax Assemblage (Factor $4 ; 9.31 \%$ of the total variance) occurs in the Pliocene. This assemblage is most common from 6.8 to $16.4 \mathrm{mbsf}$ (Sections 121-754A-2H-1 to -3H-1). Small peaks of this assemblage are also found in the lower upper Miocene (Sample 121$754 \mathrm{~A}-6 \mathrm{H}-1,70-75 \mathrm{~cm}$ ). Astrononion echolsi, Bulimina mexicana, and Karreriella bradyi dominate this assemblage.

Lenticulina spp. Varimax Assemblage (Factor 5; $13.55 \%$ of the total variance) develops in two horizons: the lower Miocene (103.3-109.3 mbsf, Sections 121-754A-12H-1 to -12H-5) and the lowermost middle Miocene (Sections $121-754 \mathrm{~A}-9 \mathrm{H}-1$ to $-9 \mathrm{H}-5$; 74.2-80.2 mbsf). This assemblage includes the following species: Bulimina tuxpamensis, Cibicidoides cf. mundulus, Planulina dohertyi, and Sphaeroidina bulloides.

Gyroidina orbicularis-Rectuvigerina striata Varimax Assemblage (Factor $6 ; 3.96 \%$ of the total variance) is recorded only in Sample 121-754A-13X-1, 70-75 cm of Oligocene age.

Ehrenbergina carinata Varimax Assemblage (Factor 7; 5.12\% of the variance) is distributed in the lowermost Pliocene (Sample 
Table 1 (continued).

\begin{tabular}{|c|c|c|c|c|c|c|c|c|c|c|c|c|c|c|c|c|}
\hline $7 \mathrm{H}-3$ & $7 \mathrm{H} \cdot 5$ & $8 \mathrm{H}-1$ & $8 \mathrm{H}-3$ & $8 \mathrm{H}-5$ & $9 \mathrm{H}-1$ & $9 \mathrm{H}-3$ & $9 \mathrm{H} \cdot 5$ & $10 \mathrm{H}-1$ & $10 \mathrm{H}-5$ & $11 \mathrm{H} \cdot 1$ & $11 \mathrm{H}-5$ & $12 \mathrm{H}-1$ & $12 \mathrm{H}-3$ & $12 \mathrm{H} \cdot 5$ & $13 X-1$ & $13 X-3$ \\
\hline $70-75$ & 70.75 & 70.75 & 70.75 & 70.75 & 70.75 & 70.75 & 70.75 & 70.75 & 70.75 & 70.75 & 70.75 & 70.75 & 70.75 & 70.75 & $70-75$ & 70.75 \\
\hline $\begin{array}{c}1 \\
13\end{array}$ & $\begin{array}{c}1 \\
10\end{array}$ & 1 & $\begin{array}{l}2 \\
1\end{array}$ & & 1 & 3 & 8 & 4 & 4 & & & & & 1 & 1 & \\
\hline 1 & & $\begin{array}{l}1 \\
3\end{array}$ & 7 & 4 & $\begin{array}{l}1 \\
1\end{array}$ & $\begin{array}{l}2 \\
1\end{array}$ & $\begin{array}{l}1 \\
1\end{array}$ & $\begin{array}{l}5 \\
4\end{array}$ & 18 & $\begin{array}{l}1 \\
3\end{array}$ & 3 & 1 & 11 & $\begin{array}{l}1 \\
4\end{array}$ & 1 & 1 \\
\hline 1 & & & 1 & & & & & 2 & 13 & 6 & 6 & & 5 & 6 & & \\
\hline 1 & & 3 & & 1 & & 5 & 5 & 3 & 1 & 4 & 1 & & 3 & 3 & 4 & \\
\hline 226 & 147 & 135 & 206 & 177 & 151 & 166 & 115 & 268 & 366 & 341 & 291 & 197 & 449 & 276 & 656 & 259 \\
\hline
\end{tabular}
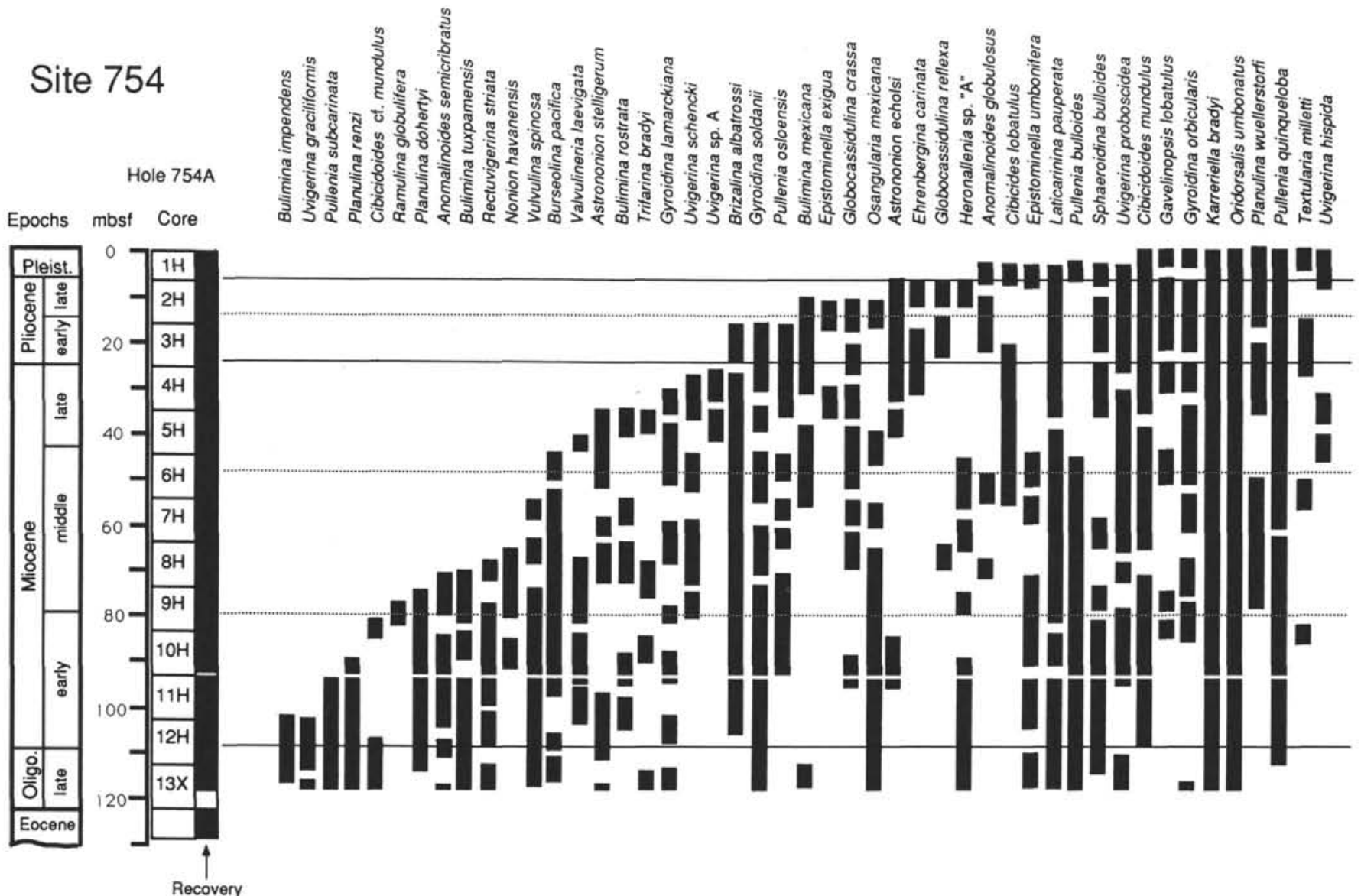

Figure 3. Stratigraphic range chart of selected benthic foraminifers at Site 754. Ranges shown by planktonic zones are based on van Morkhoven et al. (1986).

121-754A-3H-5, 70-75 cm) and Pleistocene (Sample 121-754A$1 \mathrm{H}-3,70-75 \mathrm{~cm})$.

In addition to the stratigraphic distribution of each varimax assemblage (= assemblage hereafter), factor loadings of $>0.5$ for each assemblage are interpreted as indicating a significant stratigraphic interval of each assemblage in this paper. The stratigraphic interval of these assemblages is summarized in Figure 11.

\section{Site 756}

The result of factor analysis with a varimax rotation is shown in Figure 10, in which six factors explain $83 \%$ of the faunal variance at Site 756 (Tables 5, 6).
Globocassidulina spp. Varimax Assemblage (Factor 1; $29.28 \%$ of the variance) generally occurs within the Neogene, but shows particularly drastic changes after the middle Miocene. Higher factor loadings $(>0.45)$ are found in eight horizons: Section 121-756B-1H-1 (0.7 mbsf), Section 121-756B-1H-5 (6.7 mbsf), Sections 121-756B-2H-5 to -3H-3 (15.2-21.8 mbsf), Sections $121-756 \mathrm{~B}-4 \mathrm{H}-1$ to $-5 \mathrm{H}-5$ (28.4-44.0 mbsf), Sections 121756B-6H-3 to $-6 \mathrm{H}-5$ (50.6-53.6 mbsf), Section 121-756B-7H-3 (59.9 mbsf), Section 121-756B-8H-3 (69.3 mbsf), and Section 121-756B-10H-3 (88.6 mbsf). This assemblage is dominated by $G$. subglobosa above the middle Miocene, and G. globosa dominates this assemblage below the middle Miocene. 

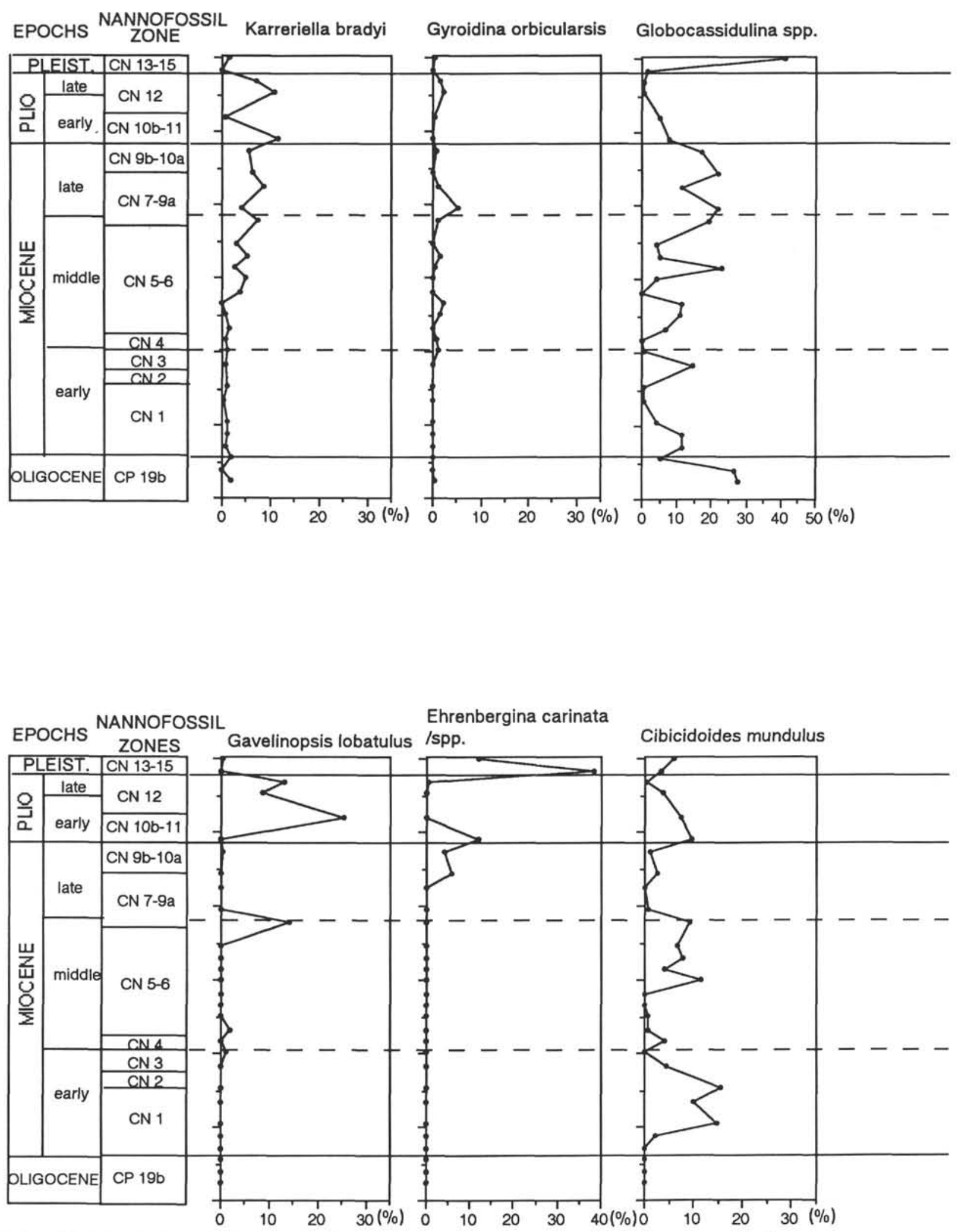

Figure 4. Relative abundance of selected benthic foraminifers plotted vs. sub-bottom depth and referred to nannofossil zones. 

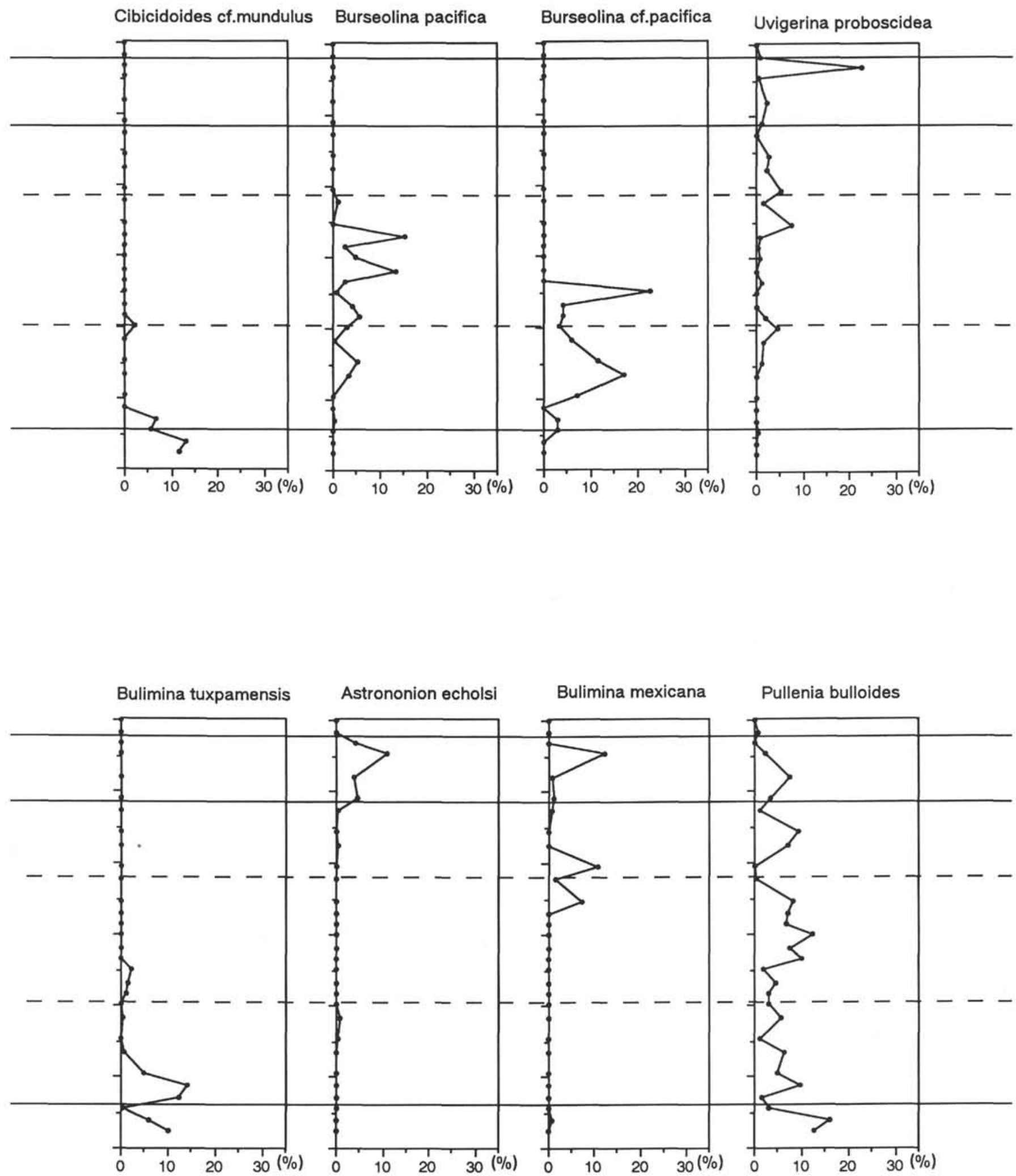

Figure 4 (continued). 

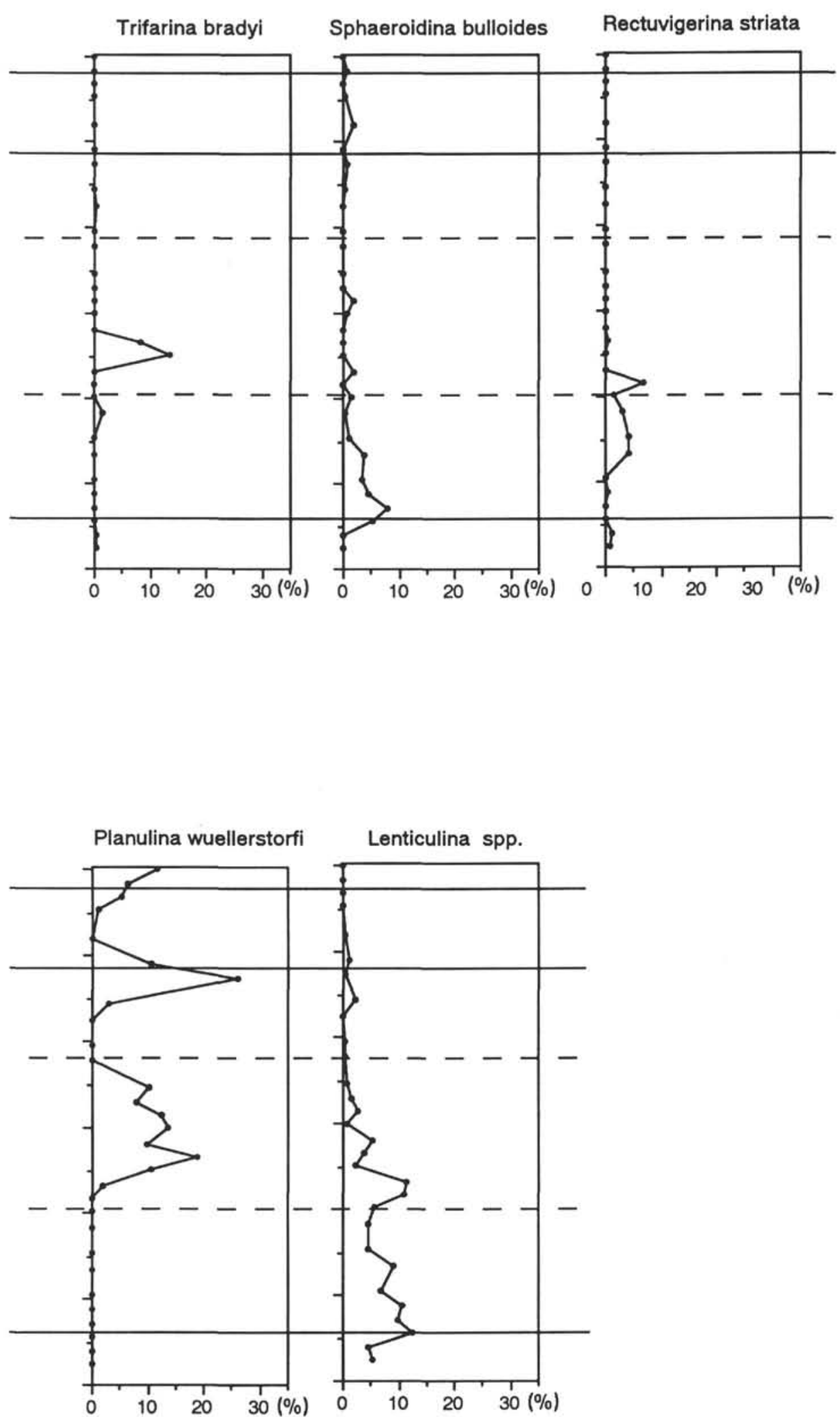

Figure 4 (continued). 


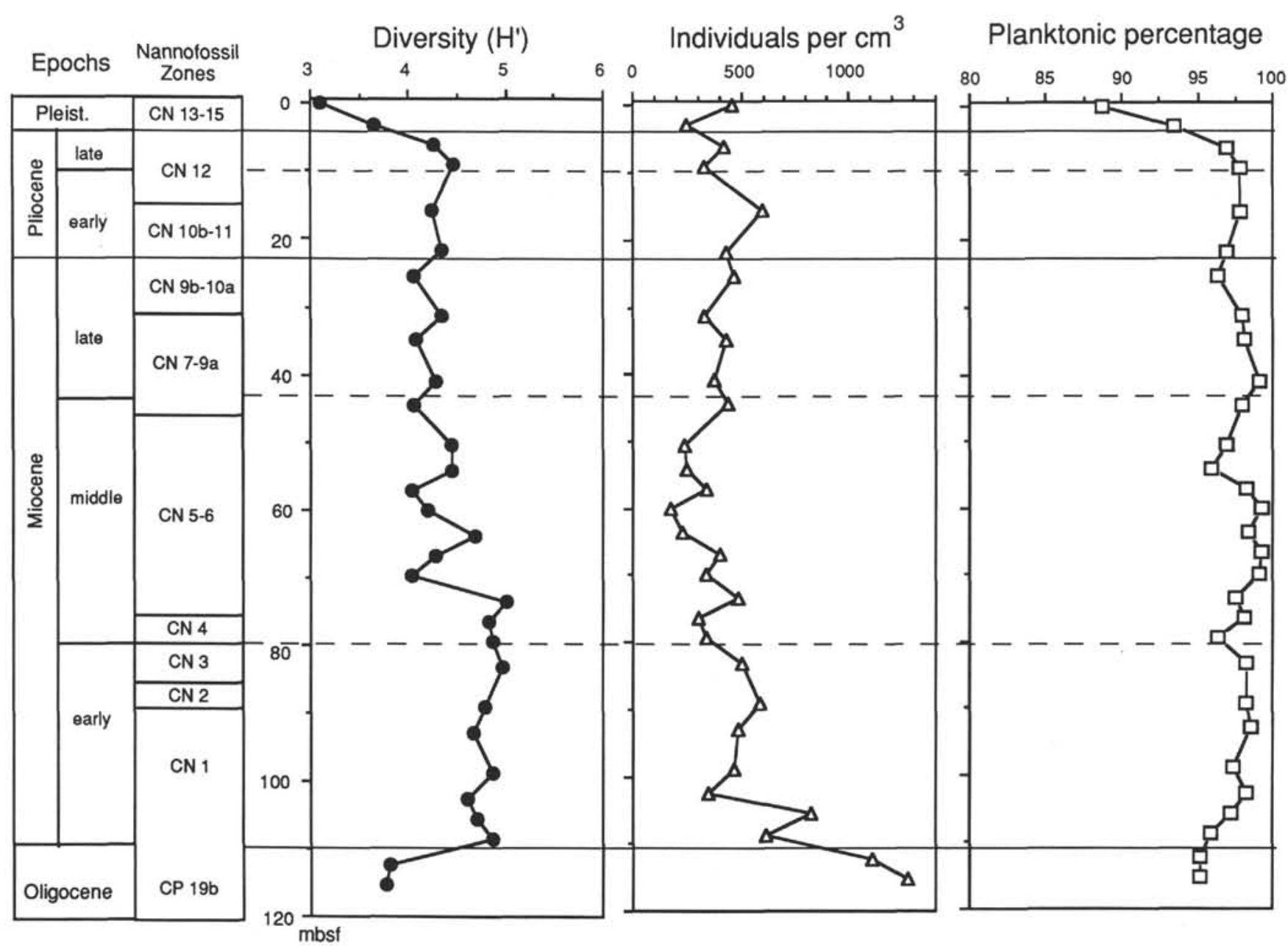

Figure 5. Species diversity, foraminifer number $/ \mathrm{cm}^{3}$, and planktonic to benthic percentages plotted vs. sub-bottom depth and referred to nannofossil zones.

Cibicidoides cf. mundulus-Oridorsalis umbonatus Varimax Assemblage (Factor 2; 22.59\% of the total variance) is best developed in the lower Oligocene (Sections 121-756B-11H-1 to $-7 \mathrm{X}-5 ; 95.3-136.5 \mathrm{mbsf})$. This assemblage is also associated with Lenticulina spp.

Epistominella umbonifera-Cibicidoides mundulus Varimax Assemblage (factor $3 ; 17.62 \%$ of the total variance) occurs mainly in the upper Oligocene and lower Miocene (Sections 121-756B$7 \mathrm{H}-1$ to $-10 \mathrm{H}-5$; 56.9-91.6 mbsf) and also is found in Sample 121-756C-4X-1, 70-75 cm (101.6 mbsf).

Globocassidulina sp. D Varimax Assemblage (Factor 4; 7.20\% of the total variance) is mainly found in the Pliocene (Samples $121-756 \mathrm{~B}-1 \mathrm{H}-3,70-75 \mathrm{~cm}$, and $-2 \mathrm{H}-1,70-75 \mathrm{~cm}$ ). This assemblage is also present in the middle Miocene (Sample 121-756B$6 \mathrm{H}-1,70-75 \mathrm{~cm}$ ).

Cibicidoides mundulus-Burseolina pacifica Varimax Assemblage (Factor $5 ; 3.80 \%$ of the total variance) is found through the lower Miocene to the lowermost middle Miocene.

Uvigerina proboscidea Varimax Assemblage (Factor 6; 5.19\% of the total variance) occurs through the upper Miocene to the Pliocene, but most typically is developed in two horizons in the lower Pliocene (Section 121-756B-3H-5; $24.8 \mathrm{mbsf}$ ) and the upper Pliocene (Section 121-756B-2H-3; 12.2 mbsf). Stilostomella lepidula is included in this assemblage.

The stratigraphic interval of these assemblages is summarized in Figure 12, where the five assemblages are represented by samples having varimax factor loadings of $>0.5$. Although the Cibicidoides mundulus-Burseolina pacifica Assemblage explains $3.80 \%$ of the total variance, the factor loadings are $<0.5$, which are less significant in comparison with those of other assemblages.

\section{Relationship between the Main Species and Known Water Masses}

Of 148 species recognized at Sites 754 and 756 , about 30 deep-sea species are reported from the Recent sediments of the Indian Ocean by Corliss $(1979 a, 1979 b, 1983)$ and Peterson (1984). Although these authors investigated mainly foraminifers occurring deeper than $\sim 2000 \mathrm{~m}$, several species closely related to certain deep water-mass characters were found in the fossil assemblages defined by this study.

Globocassidulina globosa is the most characteristic species for the Indian Deep Water (IDW), which is known to be largely of Atlantic origin (North Atlantic Deep Water (NADW)), derived from the South Atlantic (Lohmann, 1978; Corliss, 1979a, 1979b, 1983; Peterson, 1984). Planulina wuellerstorfi, Astrononion echolsi, and Pullenia bulloides are reported as the representative species associated with warm and high-salinity NADW in the southwest Indian Ocean (Corliss, 1983). Uvigerina and Eggerella bradyi are strongly associated with IDW (Peterson, 1984). The occurrence of Uvigerina in the Southeast Indian Ocean further indicates the presence of Circumpolar Deep Water (Corliss, 
Table 2. Occurrence of benthic foraminifers at Site 756.

\begin{tabular}{|c|c|c|c|c|c|c|c|c|c|c|c|c|}
\hline Hole & $756 \mathrm{~B}-$ & & & & & & & & & & & \\
\hline Sections & $1 \mathrm{H}-1$ & $1 \mathrm{H} \cdot 3$ & $1 \mathrm{H}-5$ & $2 \mathrm{H}-1$ & $2 \mathrm{H} \cdot 3$ & $2 \mathrm{H} \cdot 5$ & $3 \mathrm{H}-1$ & $3 \mathrm{H}-3$ & T3H-5 & $4 \mathrm{H}-1$ & $4 \mathrm{H}-3$ & $4 \mathrm{H}-5$ \\
\hline Intervals (cm) & 70.75 & 70.75 & $70-75$ & 70.75 & 70.75 & 70.75 & 70.75 & 70.75 & 70.75 & 70.75 & 70.75 & 70.75 \\
\hline $\begin{array}{l}\text { Allomorphina pacifica } \\
\text { Allomorphina sp } \\
\text { Amphicoryna scalaris } \\
\text { Amphicoryna spp. } \\
\text { Anomalina flintii } \\
\end{array}$ & 1 & & & & & & & & & & & \\
\hline $\begin{array}{l}\text { Anomalina spp. } \\
\text { Anomalinoides cf. flintii } \\
\text { Anomalinoides globulosus } \\
\text { Anomalinoides pseudogrosserugosus } \\
\text { Anomalinoides semicribratus } \\
\end{array}$ & & & & 1 & & & & & & & & \\
\hline $\begin{array}{l}\text { Anomalinoides spp. } \\
\text { Astacolus spp. } \\
\text { Astrononion echolsi } \\
\text { Astrononion sterigerum } \\
\text { Astrononion spp. }\end{array}$ & 21 & 11 & 3 & 2 & & $\begin{array}{l}1 \\
1 \\
1\end{array}$ & 1 & & & 7 & $\begin{array}{l}2 \\
1\end{array}$ & \\
\hline $\begin{array}{l}\text { Bolivina spp. } \\
\text { Bolivinopsis cubensis } \\
\text { Brizalina albatrossi } \\
\text { Brizalina byramensis } \\
\text { Brizalina pseudoplicata }\end{array}$ & & 9 & 1 & & 4 & 7 & 1 & 2 & 9 & $\begin{array}{l}11 \\
6\end{array}$ & $\begin{array}{l}5 \\
2\end{array}$ & $\begin{array}{l}7 \\
2\end{array}$ \\
\hline $\begin{array}{l}\text { Brizalina pusilla } \\
\text { Brizalina ct. pusilla } \\
\text { Brizalina thalmanni } \\
\text { Brizalina spp. } \\
\text { Bulimina carteri } \\
\end{array}$ & 1 & & $\begin{array}{l}3 \\
1\end{array}$ & & 5 & 1 & $\begin{array}{l}1 \\
6\end{array}$ & 9 & & & 1 & \\
\hline $\begin{array}{l}\text { Bulimina impedens } \\
\text { Bulimina jarvisi } \\
\text { Bulimina macilenta } \\
\text { Bulimina mexicana } \\
\text { Bulimina ct. mexicana }\end{array}$ & & & & & 1 & & 4 & $\begin{array}{l}5 \\
1\end{array}$ & 2 & & & 1 \\
\hline $\begin{array}{l}\text { Bulimina rostrata } \\
\text { Bulimina sp. B } \\
\text { Bulimina spp. } \\
\text { Bulimina tuxpamensis } \\
\text { Buliminella sculpturata }\end{array}$ & 5 & 2 & 3 & 1 & 2 & 6 & 3 & 1 & 2 & 2 & 1 & 2 \\
\hline $\begin{array}{l}\text { Buliminella cf. sculpturata } \\
\text { Burseolina pacifica } \\
\text { Cassidulina carinata } \\
\text { Cibicides spp. } \\
\text { Cibicidina walli }\end{array}$ & $\begin{array}{l}2 \\
1\end{array}$ & 1 & & & & & 1 & & & & 1 & \\
\hline $\begin{array}{l}\text { Cibicidina cl. wall } i \\
\text { Cibicidoides alazanensis } \\
\text { Cibicidoides bradyi } \\
\text { Cibicidoides grossepertoratus } \\
\text { Cibicidoides havanensis }\end{array}$ & & & 2 & & & & & & & & & \\
\hline $\begin{array}{l}\text { Cibicidoides incrassatus } \\
\text { Cibicidoides laurisae } \\
\text { Cibicidoides cf. laurisae } \\
\text { Cibicidoides matanzasensis } \\
\text { Cibicidoides mexicanus } \\
\end{array}$ & & & & & & & & & 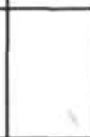 & & & \\
\hline $\begin{array}{l}\text { Cibicidoides mundulus } \\
\text { Cibicidoides cf. mundulus } \\
\text { Cibicidoides spp. } \\
\text { Dentalina hircicornua } \\
\text { Dentalina communis }\end{array}$ & $\begin{array}{c}12 \\
1\end{array}$ & , & 17 & 2 & 4 & $\begin{array}{l}6 \\
3\end{array}$ & 13 & $\begin{array}{l}9 \\
8 \\
1\end{array}$ & 2 & $\begin{array}{l}3 \\
3 \\
2\end{array}$ & $\begin{array}{c}15 \\
3\end{array}$ & $\begin{array}{l}5 \\
5\end{array}$ \\
\hline $\begin{array}{l}\text { Dentalina spp. } \\
\text { Discorbis subvilardeboanus } \\
\text { Dorothia brevis } \\
\text { Dorothia c1. brevis } \\
\text { Dorothia spp. }\end{array}$ & 1 & & 1 & & 1 & 2 & & 2 & 2 & 2 & 1 & 2 \\
\hline $\begin{array}{l}\text { Eggerella bradyi } \\
\text { Eggerella spp. } \\
\text { Ehrenbergina carinata } \\
\text { Ehrenbergina hystrix } \\
\text { Ehrenbergina sp. }\end{array}$ & & & 2 & 11 & 2 & 1 & 2 & $\begin{array}{l}6 \\
3\end{array}$ & 3 & 1 & 2 & 2 \\
\hline $\begin{array}{l}\text { Ellipsoidella spp. } \\
\text { Ellipsoidina spp. } \\
\text { Epistominella exigua } \\
\text { Epistominella ct. exigua } \\
\text { Epistominella umbonifera }\end{array}$ & $\begin{array}{c}1 \\
15\end{array}$ & $\begin{array}{l}3 \\
4\end{array}$ & 1 & 6 & 10 & $\begin{array}{l}9 \\
7\end{array}$ & 1 & $\begin{array}{l}1 \\
5\end{array}$ & 1 & $\begin{array}{l}1 \\
8\end{array}$ & $\begin{array}{l}1 \\
2\end{array}$ & 1 \\
\hline $\begin{array}{l}\text { Epistominella c. umbonitera } \\
\text { Epistominella spp. } \\
\text { Fissurina spp. } \\
\text { Evolvocassidulina spp. } \\
\text { Gaudryina sp. }\end{array}$ & 7 & 2 & $\begin{array}{c}14 \\
1\end{array}$ & 4 & 4 & 1 & 1 & 4 & 3 & 4 & & 3 \\
\hline $\begin{array}{l}\text { Gavelinopsis lobatulus } \\
\text { Glandulina spp. } \\
\text { Glandulopleurostomella spp. } \\
\text { Globocassidulina ct. decorata } \\
\text { Globocassidulina subalobosa (s.l.) + globosa }\end{array}$ & $\begin{array}{l}6 \\
2 \\
56\end{array}$ & 2 & 44 & $\begin{array}{l}8 \\
1\end{array}$ & 10 & 17 & 26 & 71 & 20 & 40 & 54 & 18 \\
\hline $\begin{array}{l}\text { Globocassidulina ct. moluccensis } \\
\text { Globocassidulina crassa } \\
\text { Globocassidulina gemma }\end{array}$ & 6 & 6 & & & & & 1 & & & & & \\
\hline
\end{tabular}


Table 2 (continued).

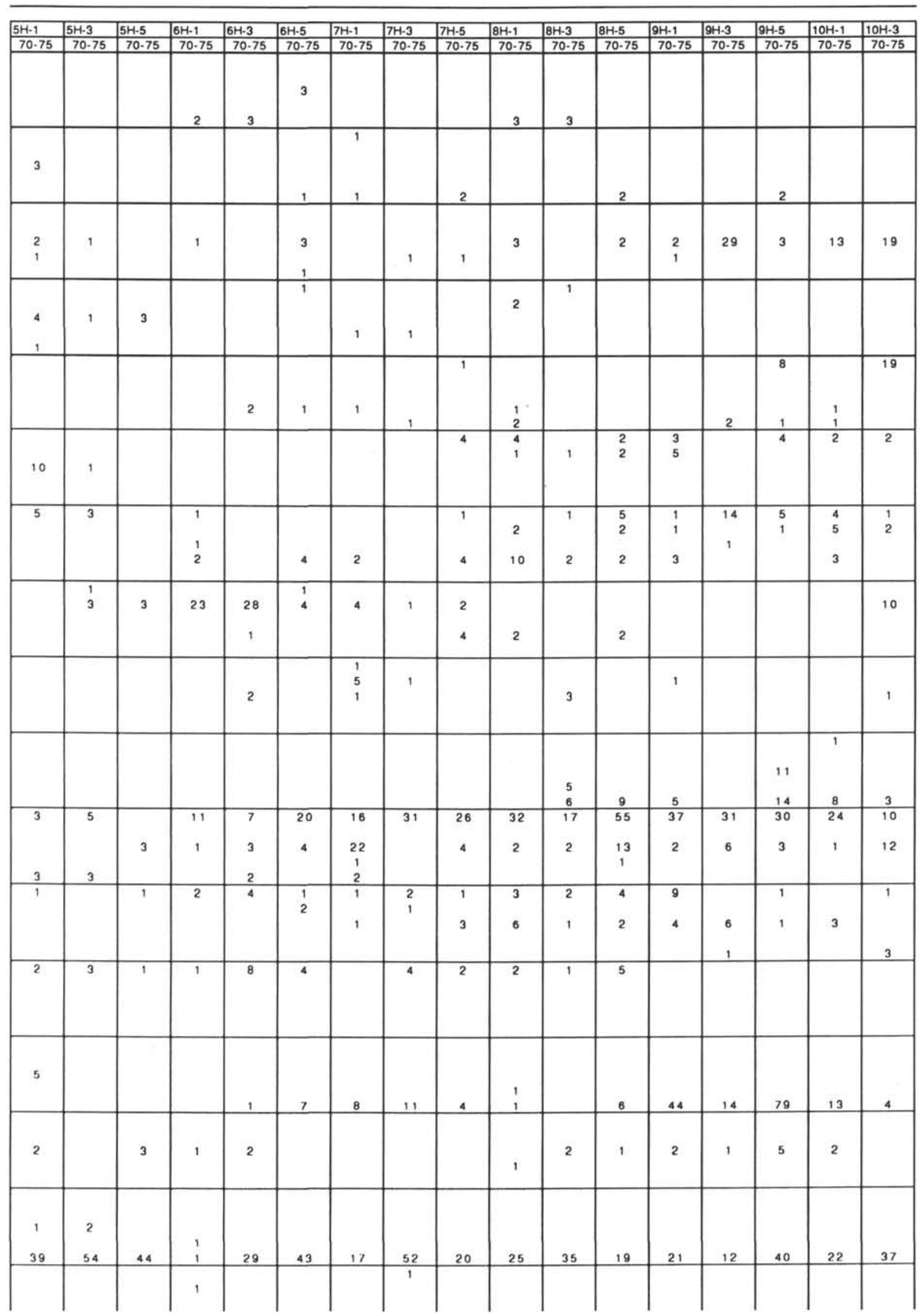




\section{R. NOMURA}

Table 2 (continued).

\begin{tabular}{|c|c|c|c|c|c|c|c|c|c|c|c|c|c|c|c|}
\hline Hole & & & & & $756 \mathrm{C}$. & & & & & & & & & & \\
\hline Sections & $10 \mathrm{H}-5$ & $11 \mathrm{H}-1$ & $11 \mathrm{H}-3$ & $11 \mathrm{H} \cdot 5$ & $4 X-1$ & $4 x \cdot 3$ & $4 X-5$ & $5 x-2$ & $5 x-5$ & $5 x-7$ & $6 x-1$ & $6 \times-3$ & $7 X-1$ & $7 x-3$ & $7 x \cdot 5$ \\
\hline Intervals $(\mathrm{cm})$ & 70.75 & 70.75 & $70-75$ & $70-75$ & $70-75$ & $70-75$ & 70.75 & $65 \cdot 70$ & $70-75$ & 70.75 & $70-75$ & 70.75 & $70-75$ & 70.75 & $70-75$ \\
\hline $\begin{array}{l}\text { Allomorphina pacifica } \\
\text { Allomorphina sp } \\
\text { Amphicoryna scalaris } \\
\text { Amphicoryna spp. } \\
\text { Anomalina tlintil }\end{array}$ & & & 4 & 1 & & & & & & & & & & & 1 \\
\hline $\begin{array}{l}\text { Anomalina spp. } \\
\text { Anomatinoides ct. llintii } \\
\text { Anomalinoides globulosus } \\
\text { Anomalinoides pseudogrosserugosus } \\
\text { Anomalinoides semicribratus }\end{array}$ & & 3 & 6 & 5 & & & 2 & 3 & 4 & 3 & $\begin{array}{l}4 \\
8\end{array}$ & $\begin{array}{l}7 \\
3 \\
7 \\
\end{array}$ & 2 & $\begin{array}{l}1 \\
1 \\
\end{array}$ & 3 \\
\hline $\begin{array}{l}\text { Anomalinoides spp. } \\
\text { Astacolus spp. } \\
\text { Astrononion echolsi } \\
\text { Astrononion sterigerum } \\
\text { Astrononion spp. } \\
\end{array}$ & 18 & $\begin{array}{l}3 \\
6\end{array}$ & 19 & 8 & 3 & 33 & 6 & 8 & $\begin{array}{l}1 \\
2\end{array}$ & $\begin{array}{l}1 \\
4 \\
5\end{array}$ & & & 2 & & \\
\hline \begin{tabular}{|l} 
Bolivina spp. \\
Bolivinopsis cubensis \\
Brizalina albatrossi \\
Brizalina byramensis \\
Brizalina pseudoplicata \\
\end{tabular} & & & & & & & & & & & & & & & \\
\hline $\begin{array}{l}\text { Brizalina pusilla } \\
\text { Brizalina ct. pusilla } \\
\text { Brizalina thaimanni } \\
\text { Brizalina spp. } \\
\text { Bulimina carteri } \\
\end{array}$ & & & 1 & & 6 & 1 & & & & & 4 & & & 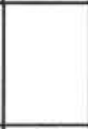 & \\
\hline $\begin{array}{l}\text { Bulimina impedens } \\
\text { Bulimina jarvisi } \\
\text { Bulimina macilenta } \\
\text { Bulimina mexicana } \\
\text { Bulimina ct. mexicana }\end{array}$ & 12 & 19 & 7 & 1 & 1 & & 1 & 8 & 11 & 4 & & 3 & 3 & 2 & 2 \\
\hline $\begin{array}{l}\text { Bulimina rostrata } \\
\text { Bulimina sp. B } \\
\text { Bulimina spp. } \\
\text { Bulimina tuxpamensis } \\
\text { Buliminella sculpturata }\end{array}$ & $\begin{array}{l}2 \\
2\end{array}$ & $\begin{array}{l}1 \\
1 \\
3\end{array}$ & $\begin{array}{l}1 \\
2 \\
2\end{array}$ & $\begin{array}{l}4 \\
9\end{array}$ & 8 & $\begin{array}{l}1 \\
3\end{array}$ & $\begin{array}{l}3 \\
1 \\
9\end{array}$ & 3 & 1 & $\begin{array}{c}10 \\
1 \\
6\end{array}$ & $\begin{array}{l}1 \\
4\end{array}$ & $\begin{array}{l}1 \\
1\end{array}$ & 2 & & 5 \\
\hline $\begin{array}{l}\text { Buliminella cf. sculpturata } \\
\text { Burseolina pacifica } \\
\text { Cassidulina carinata } \\
\text { Cibicides spp. } \\
\text { Cibicidina walli } \\
\end{array}$ & & 14 & $\begin{array}{l}1 \\
1 \\
\end{array}$ & $\begin{array}{l}1 \\
5 \\
\end{array}$ & 6 & & & & & & & 1 & 2 & 1 & \\
\hline $\begin{array}{l}\text { Cibicidina ct. wall } \mathrm{I} \\
\text { Cibicidoides alazanensis } \\
\text { Cibicidoides bradyi } \\
\text { Cibicidoides grossepertoratus } \\
\text { Cibicidoides havanensis } \\
\end{array}$ & 9 & 12 & 14 & 49 & & 15 & & 4 & 3 & 3 & 1 & 4 & 3 & $\begin{array}{l}2 \\
4 \\
\end{array}$ & $\begin{array}{l}5 \\
1 \\
\end{array}$ \\
\hline $\begin{array}{l}\text { Cibicidoides incrassatus } \\
\text { Cibicidoides laurisae } \\
\text { Cibicidoides c1. laurisae } \\
\text { Cibicidoides matanzasensis } \\
\text { Cibicidoides mexicanus } \\
\end{array}$ & & 15 & & & 9 & & 4 & 14 & 4 & $\begin{array}{r}4 \\
18 \\
\end{array}$ & 35 & 12 & $\begin{array}{l}10 \\
9 \\
\end{array}$ & $\begin{array}{l}2 \\
1 \\
\end{array}$ & $\begin{array}{l}3 \\
9 \\
\end{array}$ \\
\hline \begin{tabular}{|l|} 
Cibicidoides mundulus \\
Cibicidoides ct. mundulus. \\
Cibicidoides spp. \\
Dentalina hircicornua \\
Dentalina communis \\
\end{tabular} & $\begin{array}{c}16 \\
1\end{array}$ & 51 & 9 & $\begin{array}{c}1 \\
32 \\
33\end{array}$ & $\begin{array}{l}9 \\
6\end{array}$ & $\begin{array}{c}14 \\
5\end{array}$ & 31 & $\begin{array}{c}26 \\
3\end{array}$ & $\begin{array}{c}29 \\
3\end{array}$ & $\begin{array}{c}30 \\
4\end{array}$ & $\begin{array}{l}24 \\
13\end{array}$ & 45 & $\begin{array}{l}3 \\
8\end{array}$ & $\begin{array}{c}20 \\
9\end{array}$ & $\begin{array}{c}14 \\
6\end{array}$ \\
\hline $\begin{array}{l}\text { Dentalina spp. } \\
\text { Discorbis subvilardeboanus } \\
\text { Dorothia brevis } \\
\text { Dorothia ct. brevis } \\
\text { Dorothia spp. } \\
\end{array}$ & 3 & 1 & 4 & 3 & 2 & $\begin{array}{l}2 \\
4\end{array}$ & $\begin{array}{l}3 \\
5\end{array}$ & 2 & 1 & 8 & $\begin{array}{l}6 \\
3\end{array}$ & $\begin{array}{l}6 \\
4\end{array}$ & $\begin{array}{l}3 \\
2\end{array}$ & 4 & 2 \\
\hline $\begin{array}{l}\text { Eggerella bradyi } \\
\text { Eggerella spp. } \\
\text { Ehrenbergina carinata } \\
\text { Ehrenbergina hystrix } \\
\text { Ehrenbergina sp. } \\
\end{array}$ & 2 & & 4 & 3 & 3 & 2 & 2 & & & 1 & & & & 1 & \\
\hline $\begin{array}{l}\text { Ellipsoidella spp. } \\
\text { Ellipsoidina spp. } \\
\text { Epistominella exigua } \\
\text { Epistominella ct, exigua } \\
\text { Epistominella umbonifera } \\
\end{array}$ & 22 & & & 3 & 20 & & 3 & 1 & & & 3 & & 1 & & 3 \\
\hline $\begin{array}{l}\text { Epistominella ct. umbonifera } \\
\text { Epistominella spp. } \\
\text { Fissurina spp. } \\
\text { Evolvocassidulina spp. } \\
\text { Gaudryina sp. }\end{array}$ & & & $\begin{array}{l}2 \\
1\end{array}$ & 1 & 1 & 3 & & & 1 & & 2 & 2 & & & \\
\hline \begin{tabular}{|l|} 
Gavelinopsis lobatulus \\
Glandulina spp. \\
Glandulopleurostomella spp. \\
Globocassidulina ct. decorata \\
Globocassidulina subglobosa (s.l.) + globosa
\end{tabular} & 15 & $\begin{array}{c}2 \\
26\end{array}$ & 3 & 51 & 13 & 33 & 32 & 36 & 34 & 24 & 29 & 17 & 13 & 17 & 24 \\
\hline $\begin{array}{l}\text { Globocassidulina ct. moluccensis } \\
\text { Globocassidulina crassa } \\
\text { Globocassidulina gemma }\end{array}$ & & & & & & & & & & & & & & & \\
\hline
\end{tabular}


Table 2 (continued).

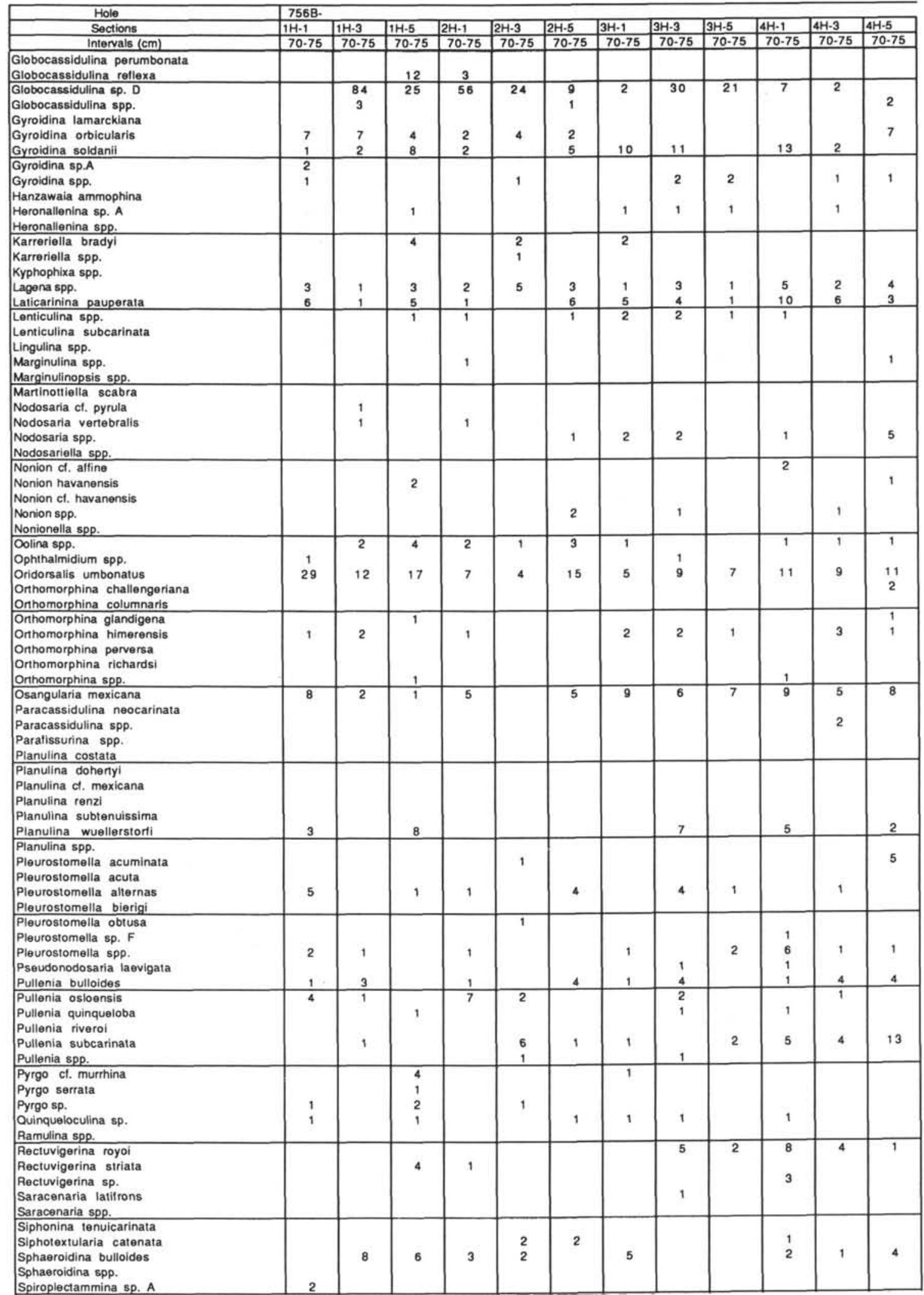


Table 2 (continued).

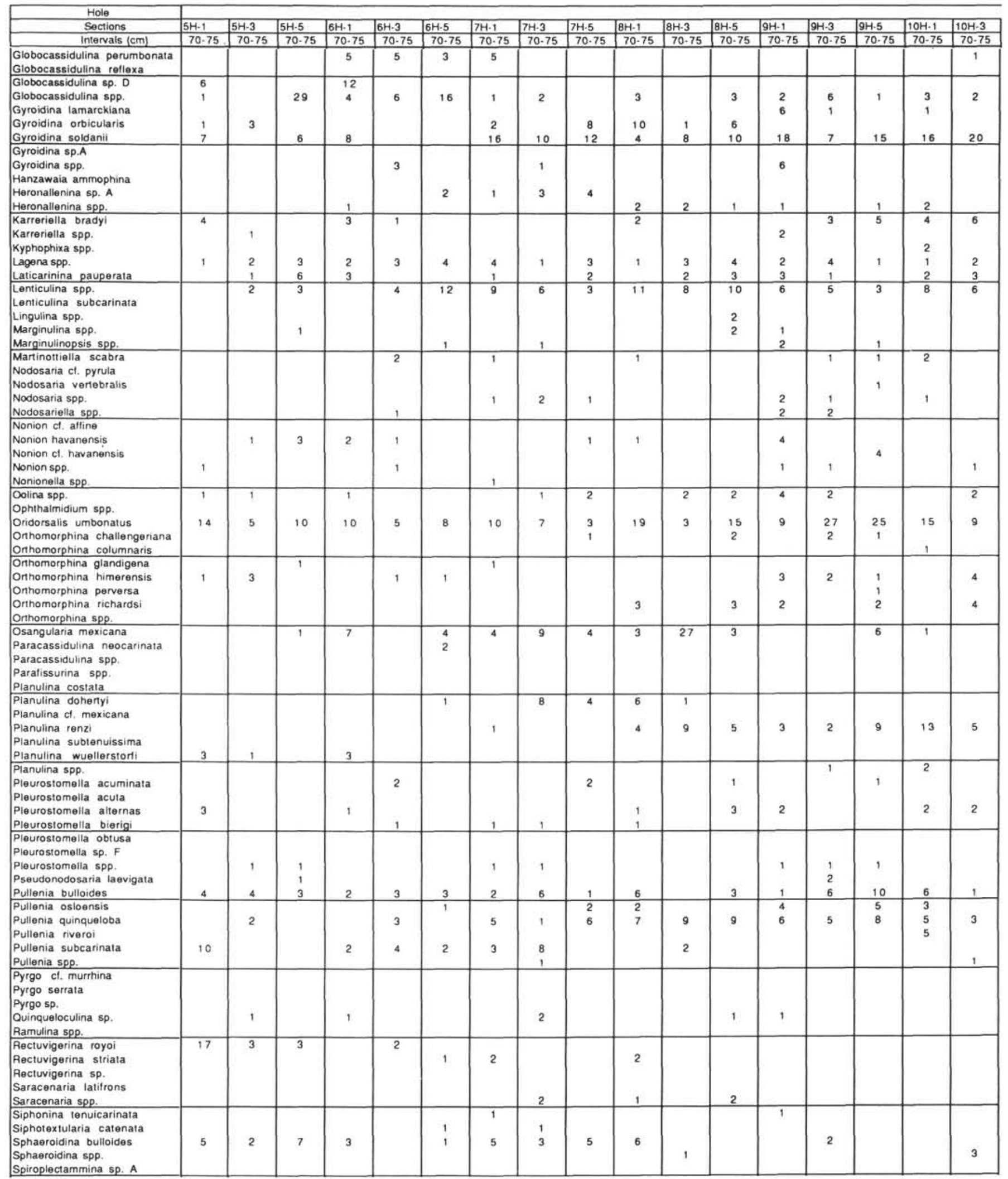


Table 2 (continued).

\begin{tabular}{|c|c|c|c|c|c|c|c|c|c|c|c|c|c|c|}
\hline \multirow{3}{*}{$\begin{array}{l}10 \mathrm{H} \cdot 5 \\
70 \cdot 75\end{array}$} & \multirow{3}{*}{\begin{tabular}{|l|l|}
$11 \mathrm{H} \cdot 1$ \\
$70 \cdot 75$
\end{tabular}} & \multirow[b]{2}{*}{$11 \mathrm{H}-3$} & \multirow[b]{2}{*}{$11 \mathrm{H}-5$} & \multicolumn{11}{|l|}{$756 \mathrm{C}-$} \\
\hline & & & & $4 X-1$ & $4 x-3$ & $4 X \cdot 5$ & $5 x-2$ & $5 x \cdot 5$ & $5 x \cdot 7$ & $6 x-1$ & $6 x-3$ & $7 x-1$ & $7 x-3$ & $7 x-5$ \\
\hline & & 70.75 & 70.75 & 70.75 & 70.75 & 70.75 & 65.70 & 70.75 & 70.75 & 70.75 & 70.75 & $70 \cdot 75$ & 70.75 & 70.75 \\
\hline & 1 & & & & & & & & & & & & & \\
\hline 3 & & & & & & & & & & & & & & \\
\hline 20 & 25 & 32 & 27 & 7 & 17 & 15 & 20 & 19 & 19 & 13 & 20 & & 12 & 14 \\
\hline & 2 & 9 & $\begin{array}{l}11 \\
2\end{array}$ & 2 & & $\begin{array}{l}1 \\
2\end{array}$ & & $\begin{array}{l}1 \\
1\end{array}$ & 1 & $\begin{array}{l}11 \\
1\end{array}$ & 1 & 10 & 1 & 6 \\
\hline 7 & 7 & 2 & 4 & & & & 5 & & 6 & & & 3 & 4 & \\
\hline $\begin{array}{l}2 \\
1 \\
\end{array}$ & 1 & 2 & 4 & $\begin{array}{l}1 \\
2 \\
\end{array}$ & 1 & $\begin{array}{l}1 \\
2 \\
1\end{array}$ & 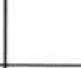 & 2 & 2 & 5 & 2 & 1 & . & 4 \\
\hline 17 & $\begin{array}{l}14 \\
1\end{array}$ & $\begin{array}{l}16 \\
2\end{array}$ & $\begin{array}{c}32 \\
1\end{array}$ & 8 & 5 & $\begin{array}{l}3 \\
4\end{array}$ & $\begin{array}{l}8 \\
1\end{array}$ & $\begin{array}{l}9 \\
\vdots\end{array}$ & 26 & 25 & $\begin{array}{l}10 \\
1 \\
2\end{array}$ & $\begin{array}{c}18 \\
3\end{array}$ & $\begin{array}{l}15 \\
2 \\
2 \\
\end{array}$ & 27 \\
\hline 1 & 2 & 2 & 3 & 1 & 1 & & 1 & 2 & & 3 & 3 & 3 & 2 & 5 \\
\hline $\begin{array}{l}3 \\
1 \\
\end{array}$ & 1 & $\begin{array}{l}2 \\
1 \\
\end{array}$ & $\begin{array}{l}2 \\
3 \\
\end{array}$ & 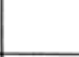 & 1 & 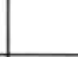 & 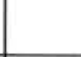 & 5 & $\begin{array}{l}4 \\
2\end{array}$ & 2 & 2 & $\begin{array}{l}1 \\
5\end{array}$ & 6 & $\stackrel{2}{1}$ \\
\hline 4 & 15 & 5 & 8 & 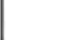 & 13 & 1 & 7 & 3 & 6 & 11 & 6 & 9 & 15 & 11 \\
\hline - & 1 & 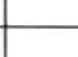 & - & 1 & $\frac{1}{1}$ & 1 & & 1 & 1 & 1 & & 1 & 4 & $\frac{1}{1}$ \\
\hline 3 & $\begin{array}{c}35 \\
3\end{array}$ & 19 & 37 & 12 & $\begin{array}{c}23 \\
2\end{array}$ & $\begin{array}{c}22 \\
1\end{array}$ & 24 & 19 & $\begin{array}{l}18 \\
1\end{array}$ & $\begin{array}{c}37 \\
2\end{array}$ & 27 & 10 & 39 & 17 \\
\hline 1 & 1 & 1 & 1 & 2 & 2 & $\vdots$ & $\begin{array}{l}1 \\
5 \\
2\end{array}$ & & & $\begin{array}{l}2 \\
2\end{array}$ & 4 & 2 & 2 & 2 \\
\hline 1 & $\begin{array}{l}2 \\
6 \\
\end{array}$ & 3 & 4 & & 1 & 1 & $\begin{array}{l}8 \\
6 \\
1 \\
\end{array}$ & $\begin{array}{l}1 \\
2\end{array}$ & & $\begin{array}{l}1 \\
6 \\
\end{array}$ & & 12 & 2 & 10 \\
\hline $\begin{array}{l}4 \\
1\end{array}$ & 1 & & & & 4 & 7 & 3 & & & & & & & \\
\hline 1 & 5 & 2 & $\begin{array}{l}3 \\
5\end{array}$ & $\begin{array}{l}1 \\
1\end{array}$ & $\begin{array}{l}2 \\
3\end{array}$ & i & $\begin{array}{l}2 \\
2\end{array}$ & & i & $\begin{array}{l}3 \\
1\end{array}$ & 7 & 1 & 1 & 1 \\
\hline 8 & $\begin{array}{c}1 \\
23 \\
\end{array}$ & 2 & 11 & 4 & 6 & $\begin{array}{l}1 \\
4\end{array}$ & $\begin{array}{l}1 \\
1 \\
3\end{array}$ & $\begin{array}{l}1 \\
5\end{array}$ & $\begin{array}{l}2 \\
14\end{array}$ & 6 & 8 & $\begin{array}{l}1 \\
4\end{array}$ & $\begin{array}{c}2 \\
18\end{array}$ & 15 \\
\hline 5 & 12 & 9 & 3 & 2 & 2 & $\begin{array}{l}3 \\
5\end{array}$ & $\begin{array}{l}3 \\
2\end{array}$ & $\begin{array}{l}2 \\
6\end{array}$ & 4 & 2 & $\begin{array}{l}6 \\
6\end{array}$ & $\begin{array}{l}9 \\
2\end{array}$ & $\begin{array}{l}6 \\
2 \\
\end{array}$ & $\begin{array}{l}1 \\
6\end{array}$ \\
\hline & & & & & & 1 & & & & & & & & 1 \\
\hline & & $\begin{array}{l}2 \\
1 \\
\end{array}$ & 5 & & & & 3 & 1 & 2 & & 2 & 1 & 1 & $\begin{array}{l}1 \\
4 \\
\end{array}$ \\
\hline 3 & & & & & & & 3 & & & & & & & \\
\hline
\end{tabular}


Table 2 (continued).

\begin{tabular}{|c|c|c|c|c|c|c|c|c|c|c|c|c|}
\hline Hole & $756 \mathrm{~B}$. & & & & & & & & & & & \\
\hline Sections & $1 \mathrm{H}-1$ & $1 \mathrm{H} \cdot 3$ & $1 \mathrm{H}-5$ & $2 \mathrm{H}-1$ & $2 \mathrm{H} \cdot 3$ & $2 \mathrm{H}-5$ & $3 \mathrm{H}-1$ & $3 \mathrm{H}-3$ & $3 \mathrm{H}-5$ & $4 \mathrm{H}-1$ & $4 \mathrm{H}-3$ & $4 \mathrm{H}-5$ \\
\hline Intervals $(\mathrm{cm})$ & 70.75 & 70.75 & 70.75 & 70.75 & $70-75$ & 70.75 & 70.75 & 70.75 & $70-75$ & $70-75$ & 70.75 & 70.75 \\
\hline $\begin{array}{l}\text { Spiroplectammina spp. } \\
\text { Stilostomella aculeata } \\
\text { Stilostomella annulifera } \\
\text { Stilostomella ct. annulifera } \\
\text { Stilostomella antillea } \\
\end{array}$ & & 2 & $\begin{array}{l}4 \\
1\end{array}$ & & 2 & 3 & 1 & 6 & 3 & $\begin{array}{l}6 \\
1 \\
\end{array}$ & 3 & \\
\hline $\begin{array}{l}\text { Stilostomella ct. antillea } \\
\text { Stilostomella capitata } \\
\text { Stilostomella fistuca } \\
\text { Stilostomella lepidula } \\
\text { Stilostomella modesta }\end{array}$ & $\begin{array}{c}2 \\
10\end{array}$ & 8 & 11 & 7 & 7 & 9 & 6 & 8 & 6 & 6 & 3 & $\begin{array}{l}11 \\
2\end{array}$ \\
\hline $\begin{array}{l}\text { Stilostomella cf. modesta } \\
\text { Stilostomella subspinosa } \\
\text { stilostomella spp. } \\
\text { Textularia milletti } \\
\text { Textularia spp. } \\
\end{array}$ & 2 & & & $\begin{array}{l}1 \\
3\end{array}$ & $\begin{array}{l}3 \\
1\end{array}$ & & 1 & 2 & 5 & 4 & 2 & 4 \\
\hline $\begin{array}{l}\text { Trifarina bradyi } \\
\text { Trifarina occidentalis } \\
\text { Tritarina sp. A } \\
\text { Trifarina sp. B } \\
\text { Trifarina sp. }\end{array}$ & & 1 & & & & & & & & & & \\
\hline $\begin{array}{l}\text { Triloculina spp. } \\
\text { Turrillina spp. } \\
\text { Uvigerina havanensis } \\
\text { Uvigerina hispida } \\
\text { Uvigerina miozea }\end{array}$ & & 4 & & 1 & & & & & & & & \\
\hline $\begin{array}{l}\text { Uvigerina proboscidea } \\
\text { Uvigerina ct. proboscidea } \\
\text { Uvigerina schencki } \\
\text { Uvigerina spinulosa } \\
\text { Uvigerina sp. A }\end{array}$ & 8 & 9 & 10 & 3 & 38 & 9 & 9 & 14 & 8 & $\begin{array}{l}16 \\
15\end{array}$ & 6 & 9 \\
\hline $\begin{array}{l}\text { Uvigerina spp. } \\
\text { Vaginulina spp. } \\
\text { valvulineria ct. laevigata } \\
\text { Vulvulina spinosa } \\
\text { Valvulineria sp. } \\
\end{array}$ & & & 1 & & & & & 1 & $T$ & & $\begin{array}{l}1 \\
1\end{array}$ & \\
\hline Agglutinated misc. & & & & & & & & & & & & \\
\hline Calcareous misc. & $\frac{1}{10}$ & 1 & 2 & 3 & $\frac{1}{1}$ & & & $\frac{2}{205}$ & $\frac{1}{120}$ & $\frac{2}{207}+x-10$ & $\frac{1}{109}$ & \\
\hline Total number of specimens & 239 & 216 & 240 & 185 & 173 & 150 & 144 & 265 & 128 & 237 & 168 & 154 \\
\hline
\end{tabular}

1983). Thus the main species found at both Broken Ridge and Ninetyeast Ridge sites are clearly related to the direct or indirect influences of NADW. In contrast, Epistominella umbonifera, which occurred as a major taxon at Site 756, is known as an index of Antarctic Bottom Water (AABW), and it is also intimately related to water undersaturated in $\mathrm{CaCO}_{3}$ (Bremer and Lohmann, 1982; Corliss, 1983; Corliss et al., 1986).

\section{DISCUSSION}

The stratigraphic distribution of Neogene benthic foraminiferal assemblages at Sites 754 and 756 reveals no major faunal turnover of a magnitude comparable to the Paleocene/Eocene boundary event; however, obvious changes occurred throughout the Oligocene to Pliocene epochs. The major faunal assemblages recognized here are similar to Atlantic faunas related to NADW, but also to Antarctic source water faunas. These faunal differences permit reconstruction of deep water changes with time at these sites, using standard benthic foraminiferal assemblage stratigraphy.

Although there are many changes of short- or long-ranged assemblages at Site 754 (Fig. 11), a major faunal change occurred between the development of the Planulina wuellerstorfi Assemblage and the decrease of the Burseolina cf. pacifica-Cibicidoides mundulus Assemblage at $\sim 13.8 \mathrm{Ma}$. The change at $13.8 \mathrm{Ma}$ is reflected in a decrease in species diversity. Other major faunal changes occurred in the decrease of the $P$. wuellerstorfi Assemblage in the late middle Miocene ( 12 Ma) and the development of the Gavelinopsis lobatulus-Uvigerina proboscidea Assemblage in the earliest Pliocene $(\sim 5 \mathrm{Ma})$. The significant decrease of the Burseolina cf. pacifica-Cibicidoides mundulus Assemblage occurred in the early Miocene $(\sim 17 \mathrm{Ma})$. The most common species in these assemblages have a known ecological preference to specific water masses, as stated in the preceding section. The paleoceanographic significance of these short-ranged assemblages (e.g., the Gyroidina orbicularis-Rectuvigerina striata Assemblage) and the assemblages represented by various unidentified species, however, could not be clarified here, because of their limited ecological information.

At Site 756, major faunal changes occurred between the decrease of the Cibicidoides $\mathrm{cf}$. mundulus-Oridorsalis umbonatus Assemblage and the development of the Epistominella umbonifera-Cibicidoides mundulus Assemblage during latest early Oligocene ( 29.8-31.7 Ma), and in the decrease of the Epistominella umbonifera-Cibicidoides mundulus Assemblage during the late early Miocene ( 17.1 Ma) (Fig. 12). The Uvigerina proboscidea Assemblage developed in the late Miocene ( 7.3 Ma). Several short-term changes represented by the assemblages, also occurred during the Pliocene.

The faunal changes described above are apparently related to paleoceanographic changes; however, the timing of the faunal changes at Sites 754 and 756 is not synchronous. The reason why the exact timing of the faunal change is different between these two sites is not clear, but might result from the difference in water depths. Site 756 is located on a southeastern slope with irregular topography, thus upwelling of deeper water may easily occur at this site. On the other hand, Site 754 , located at the center of the flat crest of Broken Ridge, may be far from direct upwelling. Similar diachronous faunal events resulting from local environmental differences between sites were noted by Thomas (1985) and Thomas and Vincent $(1987,1988)$.

The faunal change at about 30-31 Ma at Site 756 may correlate with the high benthic foraminiferal $\delta^{18} \mathrm{O}$ event near the early/late Oligocene boundary that was recognized in many DSDP sites, e.g., Sites 366 and 558 (Miller and Fairbanks, 1985; Miller et al., 
Table 2 (continued).

\begin{tabular}{|c|c|c|c|c|c|c|c|c|c|c|c|c|c|c|c|c|c|}
\hline Hole & & & & & & & & & & & & & & & & & \\
\hline Sections & $5 \mathrm{H}-1$ & $5 \mathrm{H}-3$ & $5 \mathrm{H}-5$ & $6 \mathrm{H}-1$ & $6 \mathrm{H}-3$ & $6 \mathrm{H} \cdot 5$ & $7 \mathrm{H}-1$ & $7 \mathrm{H} \cdot 3$ & $7 \mathrm{H} .5$ & $8 \mathrm{H} \cdot 1$ & $8 \mathrm{H}-3$ & $8 \mathrm{H} \cdot 5$ & $9 \mathrm{H}-1$ & $9 \mathrm{H}-3$ & $9 \mathrm{H} \cdot 5$ & $10 \mathrm{H}-1$ & $10 \mathrm{H}-3$ \\
\hline Intervals $(\mathrm{cm})$ & 70.75 & 70.75 & 70.75 & 70.75 & 70.75 & 70.75 & 70.75 & 70.75 & 70.75 & 70.75 & 70.75 & 70.75 & 70.75 & 70.75 & $70 \cdot 75$ & 70.75 & $70 \cdot 75$ \\
\hline \begin{tabular}{|l|} 
Spiroplectammina spp. \\
Stilostomella aculeata \\
Stilostomella annulifera \\
Stilostomella ct. annulitera \\
Stilostomella antillea \\
\end{tabular} & & 1 & 1 & & 3 & 1 & 1 & 7 & $\begin{array}{l}5 \\
2\end{array}$ & 4 & & 3 & & 7 & 2 & & \\
\hline $\begin{array}{l}\text { Stilostomella ct. antillea } \\
\text { Stilostomella capitata } \\
\text { Stilostomella fistuca }\end{array}$ & 3 & 3 & & 3 & 6 & 3 & 3 & 4 & 13 & 6 & 2 & 17 & 11 & 10 & 10 & $\begin{array}{l}10 \\
1\end{array}$ & 5 \\
\hline $\begin{array}{l}\text { Stilostomella lepidula } \\
\text { Stilostomella modesta }\end{array}$ & 5 & 1 & $\begin{array}{l}7 \\
3 \\
\end{array}$ & $\begin{array}{l}7 \\
1 \\
\end{array}$ & 6 & 2 & 1 & 1 & $\begin{array}{l}3 \\
1 \\
\end{array}$ & $\begin{array}{c}6 \\
12 \\
\end{array}$ & 2 & $\begin{array}{l}6 \\
1\end{array}$ & $\begin{array}{l}8 \\
3 \\
\end{array}$ & $\begin{array}{l}7 \\
3 \\
\end{array}$ & 7 & $\begin{array}{l}4 \\
1 \\
\end{array}$ & 5 \\
\hline $\begin{array}{l}\text { Stilostomella ct. modesta } \\
\text { Stilostomella subspinosa } \\
\text { Stilostomella spp. } \\
\text { Textularia milletti } \\
\text { Textularia spp. }\end{array}$ & 6 & 4 & 4 & 1 & 1 & 2 & 1 & 1 & & 4 & 2 & 3 & & 7 & $\begin{array}{l}1 \\
5\end{array}$ & 6 & 6 \\
\hline $\begin{array}{l}\text { Trifarina bradyi } \\
\text { Trifarina occidentalis } \\
\text { Tritarina sp. A } \\
\text { Tritarina sp. B } \\
\text { Trifarina sp. }\end{array}$ & & & 2 & $\begin{array}{l}3 \\
5\end{array}$ & & 3 & 13 & & & & & & 3 & & & & \\
\hline $\begin{array}{l}\text { Triloculina spp. } \\
\text { Turrillina spp. } \\
\text { Uvigerina havanensis } \\
\text { Uvigerina hispida } \\
\text { Uvigerina miozea } \\
\end{array}$ & & & & & & & & & $\begin{array}{l}1 \\
4\end{array}$ & 14 & 7 & 5 & & $\begin{array}{l}1 \\
3 \\
\end{array}$ & & & \\
\hline $\begin{array}{l}\text { Uvigerina proboscidea } \\
\text { Uvigerina ct. proboscidea } \\
\text { Uvigerina schencki } \\
\text { Uvigerina spinulosa } \\
\text { Uvigerina sp. A }\end{array}$ & $\begin{array}{l}2 \\
14\end{array}$ & 1 & 2 & 1 & 1 & 10 & 2 & 1 & 2 & 12 & 2 & 7 & 51 & 10 & $\begin{array}{l}6 \\
4 \\
8\end{array}$ & $\begin{array}{l}3 \\
2 \\
1 \\
\end{array}$ & $\begin{array}{l}2 \\
5\end{array}$ \\
\hline $\begin{array}{l}\text { Uvigerina spp. } \\
\text { Vaginulina spp. } \\
\text { Valvulineria ct. laevigata } \\
\text { Vulvulina spinosa } \\
\text { Valvulineria } s p .\end{array}$ & 1 & $\begin{array}{l}1 \\
1\end{array}$ & & 3 & $\begin{array}{l}5 \\
1\end{array}$ & 1 & $\begin{array}{l}1 \\
1 \\
3\end{array}$ & $\begin{array}{l}6 \\
1 \\
1 \\
1\end{array}$ & $\begin{array}{l}2 \\
2 \\
3\end{array}$ & $\begin{array}{l}3 \\
6\end{array}$ & 4 & $\begin{array}{l}5 \\
3\end{array}$ & $\begin{array}{l}2 \\
1\end{array}$ & 1 & 10 & $\begin{array}{l}3 \\
4\end{array}$ & $\begin{array}{l}1 \\
3\end{array}$ \\
\hline Agglutinated misc. & & & & & & & 1 & & 1 & & & & & & 1 & & 2 \\
\hline Calcareous misc. & 2 & 4 & 1 & 5 & & 2 & 3 & 1 & 8 & 5 & 5 & 1 & 2 & 3 & 2 & 3 & 4 \\
\hline Total number of specim & 196 & 136 & 158 & 148 & 164 & 191 & 193 & 208 & 192 & 276 & 184 & 277 & 319 & 258 & 367 & 236 & 232 \\
\hline
\end{tabular}

1989), Sites 77 and 574 (Keigwin and Keller, 1984; Miller and Thomas, 1985). This shift to more positive values of $\delta^{18} \mathrm{O}$ was also detected between $\sim 90$ and 100 mbsf in Hole 756B (Rea et al., this volume). High oxygen isotopic values suggest the existence of significant continental ice at that time (Miller and Fairbanks, 1985). The common occurrence of Epistominella umbonifera in the upper Oligocene and lower Miocene suggests the involvement of Antarctic-source corrosive water in the intermediate water. The development of corrosive water, as indicated by the presence of E. umbonifera, is suggested to have occurred in the middle Oligocene in the Atlantic Ocean (Miller, 1983; Boersma, 1985), though E. umbonifera occurred abundantly from the middle Eocene at ODP Sites 689 and 690 (Thomas, 1990).

The faunal change at $\sim 17.1$ Ma may correlate with the faunal event at 17-15 Ma, reported by Thomas and Vincent $(1987,1988)$ from central Pacific Site 575 and North Atlantic Sites 608 and 610 (Thomas, 1986b), and close to that of North Atlantic Sites 558 and 563 (Miller and Katz, 1987). According to these authors, the timing of this faunal change pre-dates the middle Miocene Antarctic ice growth and cooling of the deep ocean water (Savin, 1977; Miller et al, 1987). The main cause of these changes may have been an increase of planktonic productivity. Thomas and Vincent (1988) noted that the benthic faunal changes may be related to development of corrosive bottom water, as a result of a large supply of biogenic silica. A decrease of the $\mathrm{CaCO}_{3}$ content, from 50.80 to $53.80 \mathrm{mbsf}$ ( $2.24 \mathrm{~m}$ above the faunal change) at Site 756 (Peirce, Weissel, et al., 1989), agrees closely with the position of the faunal change at this site, and falls within the range of 17-15 Ma of Thomas and Vincent $(1987,1988)$. Therefore, the idea of a correlation between faunal events and $\mathrm{CaCO}_{3}$ content (Thomas and Vincent, 1987; 1988), is in agreement with results of this study. Furthermore, a positive shift in $\delta^{13} \mathrm{C}$ values of benthic foraminifers was detected from the lower to middle Miocene at this site (Rea et al., this volume).

The fauna after 17.1 Ma suggests a decrease in production of carbonate-corrosive intermediate water, because of the reduction of the Epistominella umbonifera-Cibicidoides mundulus Assemblage. A decrease in the volume of carbonate-corrosive water is also suggested by lower $\delta^{18} \mathrm{O}$ values in the latest early Miocene (Rea et al., this volume). These isotopic data indicate that the faunal change at 17.1 Ma may have been caused primarily by the change in surface ocean productivity, in support of the view of Thomas and Vincent $(1987,1988)$ and Miller and Katz (1987).

The decrease of the Burseolina cf. pacifica-Cibicidoides mundulus Assemblage at $\sim 17 \mathrm{Ma}$ at Site 754 can be correlated with that of the Epistominella umbonifera-Cibicidoides mundulus Assemblage at Site 756, suggesting the decrease of carbonate-corrosive intermediate water. However, the development of the Planulina wuellerstorfi Assemblage during the middle Miocene $(\sim 14-12 \mathrm{Ma})$ is noted at Site 754 . The isotopic data at DSDP Site 216 (Vincent et al., 1985) and at Site 754 show that the increase of $\delta^{18} \mathrm{O}$ from Zone $\mathrm{CN} 3 / 4$ to $\mathrm{CN} 5 \mathrm{~b}$ is inversely related to the development of the Planulina wuellerstorfi Assemblage after 13.8 Ma. Similarly $P$. wuellerstorfi appeared in the middle Miocene at about $14 \mathrm{Ma}$ at DSDP Sites 563,608, and 610 in the North Atlantic Ocean (Thomas, 1986b; Miller and Katz, 1987). The timing of the development of the P. wuellerstorfi Assemblage in the Atlantic Ocean and the Indian Ocean seems to be almost synchronous, and is correlated with the timing of bottom water temperature drop at 14.8-13.5 Ma (Miller and Katz, 1987; Miller et al., 1987). According to Thomas (1986b), the first occurrence of Planulina wuellerstorfi corresponds to the increased value of oxygen isotope ratio in the middle Miocene of the North Atlantic Ocean (14.814.1 Ma; Thomas and Vincent, 1987), though it occurred earlier 
Table 2 (continued).

\begin{tabular}{|c|c|c|c|c|c|c|c|c|c|c|c|c|c|c|c|}
\hline Hole & & & & & $756 \mathrm{C}$. & & & & & & & & & & \\
\hline Sections & $10 \mathrm{H}-5$ & $11 \mathrm{H} \cdot 1$ & $11 \mathrm{H} \cdot 3$ & $11 \mathrm{H} \cdot 5$ & $4 x \cdot 1$ & $4 x-3$ & $4 x-5$ & $5 x-2$ & $5 \times \cdot 5$ & $5 \times-7$ & $6 x \cdot 1$ & $6 x-3$ & $7 x \cdot 1$ & $7 x-3$ & $7 x-5$ \\
\hline Intervals (cm) & 70.75 & 70.75 & 70.75 & 70.75 & 70.75 & $70 \cdot 75$ & 70.75 & $65 \cdot 70$ & 70.75 & 70.75 & 70.75 & 70.75 & 70.75 & 70.75 & 70.75 \\
\hline $\begin{array}{l}\text { Spiroplectammina spp. } \\
\text { Stilostomella aculeata } \\
\text { Stilostomella annulifera } \\
\text { Stilostomella ct. annulitera } \\
\text { Stilostomella antillea }\end{array}$ & & & & & 1 & & 0.70 & & & & & 3 & & & \\
\hline $\begin{array}{l}\text { Stilostomella ct. antillea } \\
\text { Stilostomella capitata } \\
\text { Stilostomella fistuca }\end{array}$ & 4 & & $\begin{array}{l}3 \\
1\end{array}$ & 1 & & 12 & 2 & 9 & 4 & & 4 & & & $\begin{array}{l}18 \\
2\end{array}$ & 2 \\
\hline $\begin{array}{l}\text { Stilostomella lepidula } \\
\text { Stilostomella modesta }\end{array}$ & 3 & 1 & 6 & $\begin{array}{l}6 \\
4\end{array}$ & 11 & 1 & $\begin{array}{l}5 \\
3\end{array}$ & $\begin{array}{l}7 \\
2\end{array}$ & $\begin{array}{l}1 \\
2\end{array}$ & 1 & 5 & 16 & 4 & 5 & 10 \\
\hline $\begin{array}{l}\text { Stilostomella ct. modesta } \\
\text { Stilostomella subspinosa } \\
\text { Stilostomella spp. } \\
\text { Textularia milletti } \\
\text { Textularia spp. }\end{array}$ & & $\begin{array}{l}8 \\
3\end{array}$ & 3 & & 3 & 2 & 1 & & 1 & 7 & 3 & & & 21 & $\begin{array}{l}3 \\
2\end{array}$ \\
\hline $\begin{array}{l}\text { Tritarina bradyi } \\
\text { Tritarina occidentalis } \\
\text { Trifarina sp. A } \\
\text { Tritarina sp. B } \\
\text { Tritarina sp. } \\
\end{array}$ & & & & 18 & & 1 & 3 & & 3 & 1 & 6 & & 1 & & 1 \\
\hline $\begin{array}{l}\text { Triloculina spp. } \\
\text { Turrillina spp. } \\
\text { Uvigerina havanensis } \\
\text { Uvigerina hispida } \\
\text { Uvigerina miozea }\end{array}$ & & & & & & & & & & & & & 1 & & \\
\hline $\begin{array}{l}\text { Uvigerina proboscidea } \\
\text { Uvigerina ct. proboscidea } \\
\text { Uvigerina schencki } \\
\text { Uvigerina spinulosa } \\
\text { Uvigerina sp. A }\end{array}$ & 8 & 3 & $\begin{array}{l}2 \\
2 \\
\end{array}$ & 2 & 1 & 1 & & 1 & & & & & & $\begin{array}{c}5 \\
46\end{array}$ & 1 \\
\hline $\begin{array}{l}\text { Uvigerina spp. } \\
\text { Vaginulina spp. } \\
\text { Valvulineria ct. laevigata } \\
\text { Vulvulina spinosa } \\
\text { Valvulineria sp. } \\
\end{array}$ & 2 & 12 & 10 & $\begin{array}{l}2 \\
15\end{array}$ & 2 & 3 & 1 & 6 & $\begin{array}{l}3 \\
6\end{array}$ & 14 & $\begin{array}{l}2 \\
8\end{array}$ & 7 & 6 & 5 & 5 \\
\hline Agglutinated misc. & 2 & & & 1 & & 2 & & & & 2 & 3 & & 3 & 1 & 2 \\
\hline Calcareous misc. & 4 & 6 & 6 & 1 & 7 & & 10 & 4 & 3 & 4 & 3 & 4 & & & 2 \\
\hline Tolal number of specimens & 212 & 355 & 253 & 426 & 164 & 226 & 214 & 252 & 208 & 265 & 305 & 252 & 175 & 305 & 242 \\
\hline
\end{tabular}

in the Pacific Ocean (16.1-15.7 Ma in the eastern Pacific and 15.0-14.9 Ma in the western Pacific; Thomas and Vincent, 1987). Therefore, the faunal change at $13.8 \mathrm{Ma}$ at Broken Ridge may have been related to a decrease in the water temperature Woodruff (1985) attributed the faunal change that occurred between 13 and $16 \mathrm{Ma}$ in the Pacific to a cooling related to Antarctic glacial expansion. The Planulina wuellerstorfi Assemblage, however, does not indicate either the effect of Antarctic corrosive water, or an increase of organic carbon. More recently, Woodruff and Savin (1989) proposed an influence of Tethyan Indian Saline Water in the early Miocene Ocean. Their results suggest that the termination of this saline water event occurred at about $14 \mathrm{Ma}$. This timing is also apparently correlated with the faunal change at Site 754. The cause of the faunal change at such intermediate water depths is complex, but it may have been due to dynamic and chemical changes of oceanic water, such as the formation of a strong thermocline.

The faunal changes at $\sim 12 \mathrm{Ma}$ at Site 754 may correlate with the timing of a peak supply of NADW into the North Atlantic basins (Miller and Katz, 1987). The modern Globocassidulina subglobosa is related to the water derived from NADW. Therefore, I interpret that the Indian Ocean intermediate water during the late middle Miocene and the late Miocene was derived from the North Atlantic.

Other faunal changes recognized at $\sim 5 \mathrm{Ma}$ at Site 754 and 7.3 $\mathrm{Ma}$ at Site 756 suggest the intensification of the low oxygen zone as inferred from the development of the Uvigerina Assemblage. This may have led to the modern intermediate water characterized by low oxygen (Wyrtki, 1973). Woodruff (1985) suggested that the faunal changes after 8-10 Ma are related to the increase of organic carbon and intensification of the low oxygen zone, and this is supported by the observed development of the Uvigerina Assemblage in this study. The low oxygen event at Site 754 occurred $\sim 2.3 \mathrm{~m}$.y. later than that at Site 756. These paleoceanographic changes in the Indian Ocean are probably related primarily to the intensification of the thermocline.

\section{ACKNOWLEDGMENTS}

I wish to thank Lisa Osterman and Patrick Quilty for reviewing the manuscript and offering useful suggestions, and Elliott Taylor for kindly helping with expression. Ellen Thomas provided constructive comments which have helped me to improve the manuscript. I thank all the shipboard scientific party of ODP Leg 121 for a great cruise and ODP staff for preparation of this publication.

\section{REFERENCES}

Berggren, W. A., and Miller, K. G., 1989. Cenozoic bathyal and abyssal calcareous benthic foraminiferal zonations. Micropaleontology, 35:308-320:

Boersma, A., 1985. Oligocene benthic foraminifers from North Atlantic sites: Benthic foraminifers as water-mass indexes in the North and South Atlantic. In Bougault, H., Cande, S. C., et al., Init. Repts. DSDP, 82: Washington (U.S. Govt. Printing Office), 611-627.

Boltovskoy, E., 1977. Neogene deep water benthonic foraminifera of the Indian Ocean. In Heirtzler, J. R., Bolli, H. M., Davies, T. A., Saunders, J. B., and Sclater, J. G. (Eds.), Indian Ocean Geology and Biostratigraphy. Washington (Am. Geophys. Union), 469-584.

1978. Late Cenozoic benthonic foraminifera of the Ninetyeast Ridge (Indian Ocean). Mar. Geol., 26:139-175.

1987. Tertiary benthic foraminifera in bathyal deposits of the Quaternary world ocean. J. Foraminiferal Res., 17:279-285.

Bremer, M. L., and Lohmann, G. P., 1982. Evidence for primary control of the distribution of certain Atlantic Ocean benthic foraminifera by degree of carbonate saturation. Deep-Sea Res., 29:987-998. 
Corliss, B. H., 1979a. Recent deep-sea benthonic foraminiferal distributions in the southeast Indian Ocean: Inferred bottom-water routes and ecological implications. Mar. Geol., 31:115-138. 1979 b. Taxonomy of Recent deep-sea benthonic foraminifera from the southeast Indian Ocean. Micropaleontology, 25:1-19. 1983. Distribution of Holocene deep-sea benthonic foraminifera in the southwest Indian Ocean. Deep-Sea Res., 30:95-117.

Corliss, B. H., Martinson, D. G., and Keffer, T., 1986. Late Quaternary deep-ocean circulation. Geol. Soc. Am. Bull., 97:1106-1121.

Culver, S., 1987. Foraminifera. In Lipps, J. H. (Ed.), Fossil Prokaryotes and Protists. Univ. of Tennessee Studies in Geology, 18:169-212.

Douglas, R. G., and Woodruff, F., 1981. Deep sea benthic foraminifera. In Emiliani, C. (Ed.), The Ocean Lithosphere, The Sea, 7: New York (Wiley), 1233-1327.

Keigwin, L. D., and Keller, G., 1984. Middle Oligocene climatic change from equatorial Pacific DSDP Site 77. Geology, 12:16-19.

Kennett, J. P., 1977. Cenozoic evolution of Antarctic glaciations, the Circum-Antarctic Ocean and their impact on global paleoceanography. J. Geophys. Res., 82:3843-3860.

Klovan, J. E., and Imbrie, J., 1971. An algorithm and Fortran IV for large scale Q-mode factor analysis. J. Int. Assoc. Math. Geol., 3:61-78.

Lohmann, G. P., 1978. Abyssal benthonic foraminifera as hydrographic indicators in the western South Atlantic. J. Foraminiferal Res., 8:634.

Miller, K. G., and Fairbanks, R. G., 1985. Oligocene to Miocene global carbon isotope cycles and abyssal circulation changes. In Sundquist, E. T., and Broecker, W. S. (Eds), The carbon cycle and atmospheric $\mathrm{CO}_{2}$ : Natural variations archean to present. Am. Geophys. Union, Geophys. Monogr., 32:469-486.

Miller, K. G., Fairbanks, R. G., and Mountain, G. S., 1987. Tertiary isotope synthesis, sea level history, and continental margin erosion. Paleoceanography, 2:1-20.

Miller, K. G., and Katz, M. E., 1987. Oligocene to Miocene benthic foraminiferal and abyssal circulation changes in the North Atlantic. Micropaleontology., 33:97-149.

Miller, K. G., and Thomas, E., 1985. Late Eocene to Oligocene benthic foraminiferal isotopic record, Site 574 equatorial Pacific. In Mayer, L., Theyer, F., et al., Init. Repts. DSDP, 85: Washington (U.S. Govt. Printing Office), 771-777.

Miller, K. G., Wright, J. D., and Brower, A., 1989. Oligocene to Miocene stable isotope stratigraphy and planktonic foraminifer biostratigraphy of the Sierra Leone Rise (DSDP Site 366 and ODP Site 667). In Ruddiman, W., Sarnthein, M., et al., Proc. ODP. Sci. Results, 108: College Station, TX (Ocean Drilling Program), 279-294.

Peirce, J., Weissel, J., et al., 1989. Proc. ODP, Init. Repts., 121: College Station, TX (Ocean Drilling Program).

Peterson, L. C., 1984. Recent abyssal benthic foraminiferal biofacies of the eastern equatorial Indian Ocean. Mar. Micropaleontol., 8:479519.

Savin, S. M., 1977. The history of the Earth's surface temperature during the past 100 million years. Ann. Rev. Earth Planet. Sci., 5:319-344.

Schnitker, D., 1980. Global paleoceanography and its deep water linkage to the Antarctic glaciation. Earth Sci. Rev., 16:1-20.

1986. North-east Atlantic Neogene benthic foraminiferal faunas: Tracers of deep-water palaeoceanography. In Summerhays, C.P., and Shackleton, N. J. (Eds.), North Atlantic Paleoceanography, Geol. Soc. Spec. Publ., 21:191-203.

Sverdrup, H. U., Johnson, M. W., and Fleming, R. H., 1942. The Oceans: Their physics, chemistry, and general biology. New York (Prentice Hall).

Thomas, E., 1985. Late Eocene to Recent deep-sea benthic foraminifers from the central equatorial Pacific Ocean. In Mayer, L., Theyer, F., et al., Init. Repts. DSDP, 85: Washington (U.S. Printing Office), 655-694.

1986a. Changes in composition of Neogene benthic foraminiferal faunas in equatorial Pacific and North Atlantic. Palaeogeogr. Palaeoclimatol., Palaeoecol., 57:47-61.

1986b. Early to Middle Miocene benthic foraminiferal faunas from DSDP Site 608 and 610, North Atlantic. In Summerhays, C. P. and Shackleton, N. J. (Eds.), North Atlantic Paleoceanography, Geol. Soc. Spec. Publ., 21:205-218.

1990. Late Cretaceous through Neogene deep-sea benthic foraminifers (Maud Rise, Weddell Sea, Antarctica). In Barker, P., Ken- nett, J, P., et al., Proc. ODP, Sci. Results, 113: College Station, TX (Ocean Drilling Program).

Thomas, E., and Vincent, E., 1987. Equatorial Pacific deep-sea benthic foraminifera: Faunal changes before the middle Miocene polar cooling. Geology, 15:1035-1039.

1988. Early to middle Miocene deep-sea benthic foraminifera in the Pacific Ocean. Rev. Paleobiol. Spec, 2 (BENTHOS' 86):583588.

van Morkhoven, F.P.C.M., Berggren, W. A., and Edwards, A. S., 1986. Cenozoic cosmopolitan deep-water benthic foraminifera. Bull. Cent. Rech. Explor.-Prod. Elf-Aquitaine, 11.

Vincent, E., Killingley, J. S., and Berger, W. H., 1985. Miocene oxygen and carbon isotope stratigraphy of the tropical Indian Ocean. In Kennett, J. P. (Ed.), The Miocene Ocean: Paleoceanography and Biogeography. Geol. Soc. Am. Mem., 163: 103-130

Woodruff, F., 1985. Changes in Miocene deep-sea benthic foraminiferal distribution in the Pacific Ocean: Relationship to paleoceanography. In Kennett, J. P. (Ed.), The Miocene Ocean: Paleoceanography and Biogeography. Geol. Soc. Am. Mem., 163:131-176.

Woodruff, F., and Douglas, R. G., 1981. Response of deep-sea benthic foraminifera to Miocene paleoclimatic events, DSDP Site 289. Mar. Micropaleontol., 6:617-632.

Woodruff, F., and Savin, S. M., 1989. Miocene deep water oceanography. Paleoceanography, 4:87-140.

Wyrtki, K., 1973. Physical oceanography of the Indian Ocean. In Zeitschel, B., and Gerlach, S. A. (Eds), The biology of the Indian Ocean, Ecological Studies, 3:Berlin (Springer-Verlag), 18-36.

Date of initial receipt: 13 March 1990

Date of acceptance: 30 October 1990

Ms 121B-139

\section{APPENDIX}

Species Index

Allomorphina pacifica Cushman and Todd, 1949

Amphicoryna scalaris $($ Batsch $)=$ Nautilus (Orthoceras) scalaris Batsch, 1791.

Anomalinoides flintii (Cushman) = Anomalina flintii Cushman, 1931 .

Anomalinoides globulosus (Chapman and Parr) $=$ Anomalina globosa Chapman and Parr, 1937

Anomalinoides pseudogrosserugosus $($ Colom $)=$ Anomalina pseudogrosserugosa Colom, 1945.

Anomalinoides semicribratus $($ Beckmann) = Anomalina pompilioides Galloway and Heminway var. semicribrata Beckmann, 1953.

Astrononion echolsi Kennett, 1967.

Astrononion stelligerum (d'Orbigny) $=$ Nonion stelligera d'Orbigny, 1839.

Bolivina cf. villalverniensis Martin, 1954

Bolivina pseudoplicata $($ Heron-Allen and Earland $)=$ Bolivina pseudopli cata Heron-Allen and Earland, 1930.

Bolivinopsis cubensis $($ Cushman and Bermudez $)=$ Spiroplectoides cubensis Cushman and Bermudez, 1937.

Brizalina albatrossi (Cushman) = Bolivina albatrossi Cushman, 1922.

Brizalina byramensis $($ Cushman $)=$ Bolivina byramensis Cushman, 1923

Brizalina $\mathrm{cf}$. pacifica (Cushman and $\mathrm{McC}$ ulloch) $=c f$. Bolivina acerosa Cushman var. pacifica Cushman and McCulloch, 1942.

Brizalina petterssoni $($ Parker $)=$ Bolivina petterssoni Parker, 1953

Brizalina pusilla (Schwager) = Bolivina pusilla Schwager, 1866.

Brizalina silvestrina (Cushman) = Bolivina silvestrina Cushman, 1936 .

Brizalina thalmanni (Renz) = Bolivina thalmanni Renz, 1948 .

Bulava indica Boltovskoy, 1976.

Buliminella carteri Bhatia, 1955.

Bulimina impendens Parker and Bermudez, 1937.

Bulimina jarvisi Cushman and Parker, 1936.

Bulimina macilenta Cushman and Parker, 1936.

Bulimina mexicana Cushman, 1922.

Bulimina rostrata Brady, 1884.

Buliminella sculpturata Keijzer, 1953.

Bulimina tuxpamensis Cole, 1928.

Burseolina pacifica (Cushman) = Cassidulina pacifica Cushman, 1925.

Cassidulina carinata Silvestri, 1896.

Cibicides lobata (d'Orbigny) = Truncatulina lobata d'Orbigny, 1839 .

Cibicidina walli Bandy, 1949.

Cibicidoides alazanensis (Nuttall) = Anomalina alazanensis Nuttall, 1937.

Cibicidoides mundulus (Brady, Parker and Jones) = Truncatulina mundula Brady, Parker and Jones, 1888. 

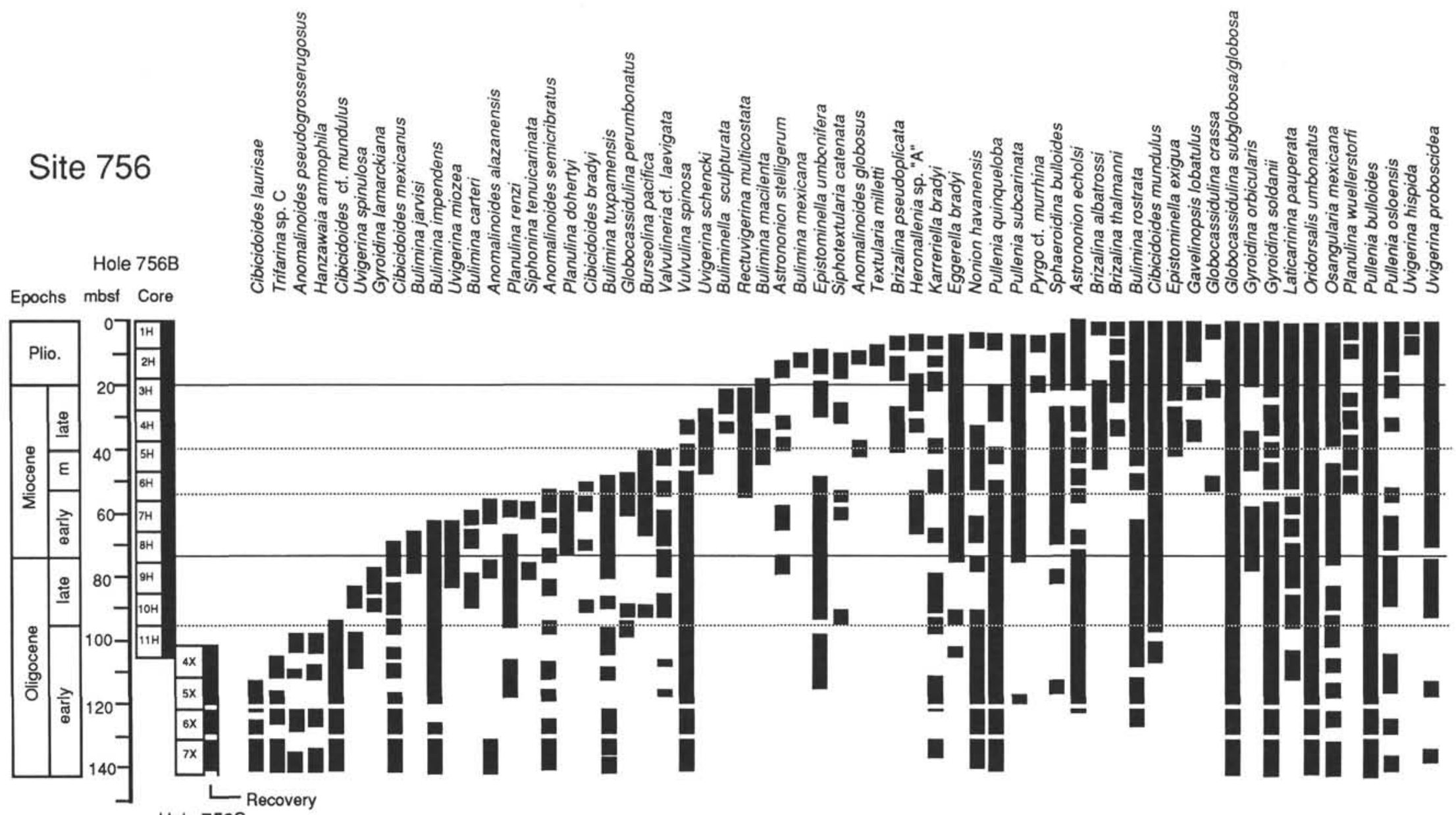

Hole $756 \mathrm{C}$

Figure 6. Stratigraphic range chart of selected benthic foraminifers at Site 756. Ranges shown by planktonic zones are based on van Morkhoven et al. (1986). 
Cibicidoides laurisae (Mallory) = Cibicides laurisae Mallory, 1959.

Cibicidoides matanzasensis (Hadley) = Planulina matanzasensis Hadley, 1934.

Cibicidoides bradyi $($ Trauth $)=$ Truncatulina bradyi Trauth, 1918 .

Cibicidoides dutemplei (d'Orbigny) = Rotalia dutemplei d'Orbigny, 1846.

Cibicidoides grosseperforatus van Morkhoven and Berggren, in Van Morkhoven, Berggren, and Edwards, 1986.

Cibicidoides havanensis $($ Cushman and Bermudez $)=$ Cibicides havanensis Cushman and Bermudez, 1937.

Cibicidoides incrassatus (Fichtel and Moll) $=$ Nautilus incrassatus Fichtel and Moll, 1798.

Cibicidoides mexicanus $($ Nuttall $)=$ Cibicides mexicana Nuttall, 1932.

Cibicidoides pachyderma $(\mathrm{Rzehak})=$ Truncatulina pachyderma $\mathrm{Rzehak}$, 1886.

Cibicidoides robertsonianus $($ Brady $)=$ Planorbulina $($ Truncatulina $)$ robertsoniana Brady, 1881.

Cibicorbis herricki Hadley, 1934.

Dentalina communis d'Orbigny, 1826.

Dentalina hircicornua $($ Schwager $)=$ Nodosaria hircicornua Schwager, 1866.

Dentalina intorta $($ Dervieux $)=$ Nodosaria intorta Dervieux, 1894 .

Discorbis sub-vilardeboanus (Rzehak) = Discorbis sub-vilardeboana Rzehak, 1888

Dorothia brevis Cushman and Stainforth, 1945.

Eggerella bradyi $($ Cushman $)=$ Verneuilina bradyi Cushman, 1911 .

Ehrenbergina carinata Eade, 1967.

Ehrenbergina hystrix Brady, 1884.

Epistominella exigua $($ Brady $)=$ Pulvinulina exigua Brady, 1884.

Epistominella umbomifera $($ Cushman $)=$ Pulvinulinella umbonifera Cush man, 1933.

Fursenkoina squammosa (d'Orbigny) =Virgulina squammosa d'Orbigny, 1826.

Gavelinopsis lobatulus $(\mathrm{Parr})=$ Discorbis lobatulus Parr, 1950.

Globocassidulina crassa (d'Orbigny) = Cassidulina crassa d'Orbigny.

Globocassidulina decorata $($ Sidebottom) $=$ Cassidulina decorata Sidebottom, 1910.

Globocassidulina horizontalis (Cushman and Renz) $=$ Cassidulina sub globosa var. horizontalis Cushman and Renz, 1941.

Globocassidulina subglobosa $($ Brady) $=$ Cassidulina subglobosa Brady 1881.

Globocassidulina alternans $($ Yabe and Hanzawa $)=$ Cassidulina alternans Yabe and Hanzawa, 1925.

Globocassidulina cf. moluccensis $($ Germeraad $)=$ Cassidulina moluccen sis Germeraad, 1946.

Globocassidulina gemma (Todd) = Cassidulina gemma Todd, 1954 .

Globocassidulina havanensis (Cushman and Bermudez) = Cassidulina havanensis Cushman and Bermudez, 1936.

Globocassidulina perumbonata $($ Keyzer $)=$ Cassidulina perumbonata Keyzer, 1953.

Globocassidulina reflex $a$ (Galloway and Wissler) $=$ Cassidulina reflexa Galloway and Wissler, 1927.

Gyroidina lamarckiana (d'Orbigny) = Rotaliana lamarckiana d'Orbigny, 1926.

Gyroidina orbicularis d'Orbigny, 1826.

Gyroidina soldanii d'Orbigny, 1826.

Hanzawaia ammophina (Gümbel) = Rotalia ammophila Gümbel, 1868.

Heronallenia sp. "A" of Boltovskoy, 1978, p. 10.

Karreriella bradyi $($ Cushman $)=$ Gaudryina bradyi Cushman, 1911 .

Kyphopyxa sp. A of Boltovskoy, 1978.

Laticarinina pauperata $($ Parker and Jones) $=$ Pulvinulina repanda var. menardii subvar. pauperata Parker and Jones, 1865.

Lenticulina subangulata (Reuss) = Cristellaria subangulata Reuss, 1862

Nodosarella pacifica Cushman, 1931

Nodosaria fistuca Schwager, 1866.

Nodosaria pyrula d'Orbigny, 1826.

Nodosaria vertebralis $($ Batsch $)=$ Nautilus (Orthoceras) vertebralis Bat sch, 1791.

Nonion havanensis Cushman and Bermudez, 1937.

Nonion affine (Reuss) = Nonionina affinis Reuss, 1851 .

Oridorsalis umbonatus (Reuss) = Rotalina umbonata Reuss, 1851.

Orthomorphina modesta $($ Bermudez $)=$ Ellipsonodosaria modesta Bermudez, 1937.

Orthomorphina antillea $($ Cushman $)=$ Nodosaria antille $a$ Cushman, 1923.
Orthomorphina challengeriana $($ Thalmann $)=$ Nodogenerina challenger ana Thalmann, 1937.

Orthomorphina columnaris (Franke) $=$ Nodosaria columnaris Franke, 1936.

Orthomorphina glandigena $($ Schwager $)=$ Nodosaria glandigena Schwager, 1866.

Orthomorphina himerensis $($ de Amicis) $=$ Nodosaria himerensis de Amicis, 1895.

Orthomorphina perversa $($ Schwager $)=$ Nodosaria perversa Schwager, 1866.

Orthomorphina richardsi $($ McLean) $=$ Nodosaria richardsi McLean, 1952.

Osangularia mexicana $($ Cole $)=$ Pulvinulinella culter $($ Parker and Jones $)$ var, mexicana Cole, 1927.

Paracassidulina minuta (Cushman) = Cassidulina minuta Cushman, 1933.

Paracassidulina neocarinata $($ Thalmann $)=$ Cassidulina neocarinata 1950.

Paracassidulina sulcata (Belford) $=$ Cassidulina sulcata Belford, 1966 .

Planulina costata $($ Hantken $)=$ Truncatulina costata Hantken, 1875 .

Planulina dohertyi $($ Galloway and Morrey) $=$ Cibicides dohertyi Galloway and Morrey, 1929.

Planulina cf. mexicana Cushman, 1927

Planulina renzi Cushman and Stainforth, 1945.

Planulina subtenuissima $($ Nuttall $)=$ Anomalina subtenuissima Nuttall, 1928.

Planulina wuellerstorfi $($ Schwager $)=$ Anomalina wuellerstorfi Schwager, 1866.

Pleurostomella acuminata Cushman, 1922

Pleurostomella acuta Hantken, 1875.

Pleurostomella alternans Schwager, 1866.

Pleurostomella bierigi Palmer and Bermudez, 1936.

Pleurostomella obtusa Berthelin, 1880.

Pullenia bulloides (d'Orbigny) $=$ Nonionina bulloides d'Orbigny, 1846 .

Pullenia subcarinata (d'Orbigny) $=$ Nonionina subcarinata d'Orbigny, 1839.

Pullenia osloensis Feyling-Hanssen, 1954.

Pullenia quinqueloba Reuss, 1867.

Pullenia riveroi Bermudez, 1939.

Pyrgo cf. murrhina $($ Schwager) = cf. Biloculina murrhina Schwager, 1866

Pyrgo serrata (Bailey) = Biloculina serrata Bailey, 1861

Ramulina globulifera Brady, 1879.

Rectuvigerina multicostata Cushman and Jarvis, 1929.

Rectuvigerina striata $($ Schwager $)=$ Dimorphina striata Schwager, 1866

Saracenaria latifrons $(\mathrm{Brady})=$ Cristellaria latifrons $\mathrm{Brady}, 1884$.

Saracenaria latifrons jamaicensis Cushman and Todd, 1945.

Siphonina pozonensis Cushman and Renz, 1941.

Siphonina tenuicarinata Cushman, 1927.

Siphotextularia catenata $($ Cushman $)=$ Textularia catenata Cushman, 1911.

Sphaeroidina bulloides d'Orbigny, 1826.

Stilostomella aculeata $($ Cushman and Renz) $=$ Ellipsonodosaria nuttalli Cushman and Jarvis var. aculeata Cushman and Renz, 1948.

Stilostomella annulifera $($ Cushman and Bermudez $)=$ Ellipsonodosaria annulifera Cushman and Bermudez, 1936.

Stilostomella lepidula $($ Schwager $)=$ Nodosaria lepidula Schwager, 1866 .

Stilostomella subspinosa (Cushman) = Ellipsonodosaria subspinosa Cushman, 1943.

Textularia flintii Cushman, 1911.

Textularia halkyardi Lalicker, 1935

Textularia milletti Cushman, 1911.

Trifarina bradyi Cushman, 1923.

Uvigerina graciliformis Papp and Turnovsky, 1953.

Uvigerina havanensis Cushman and Bermudez, 1936.

Uvigerina hispida Schwager, 1866.

Uvigerina mexicana Nuttall, 1932.

Uvigerina miozea Finlay, 1939.

Uvigerina peregrina Cushman, 1923.

Uvigerina proboscidea Schwager, 1866.

Uvigerina schencki Asano, 1950.

Uvigerina spinulosa Hadley, 1934.

Vaginulina legumen $($ Linnaeus) $=$ Nautilus legumen Linnaeus, 1758.

Valvulineria laevigata Phleger and Parker, 1951.

Vulvulina spinosa Cushman, 1927 
Uvigerina sp. A Uvigerina proboscidea Stilostomella lepidula Orthomorphina antillea

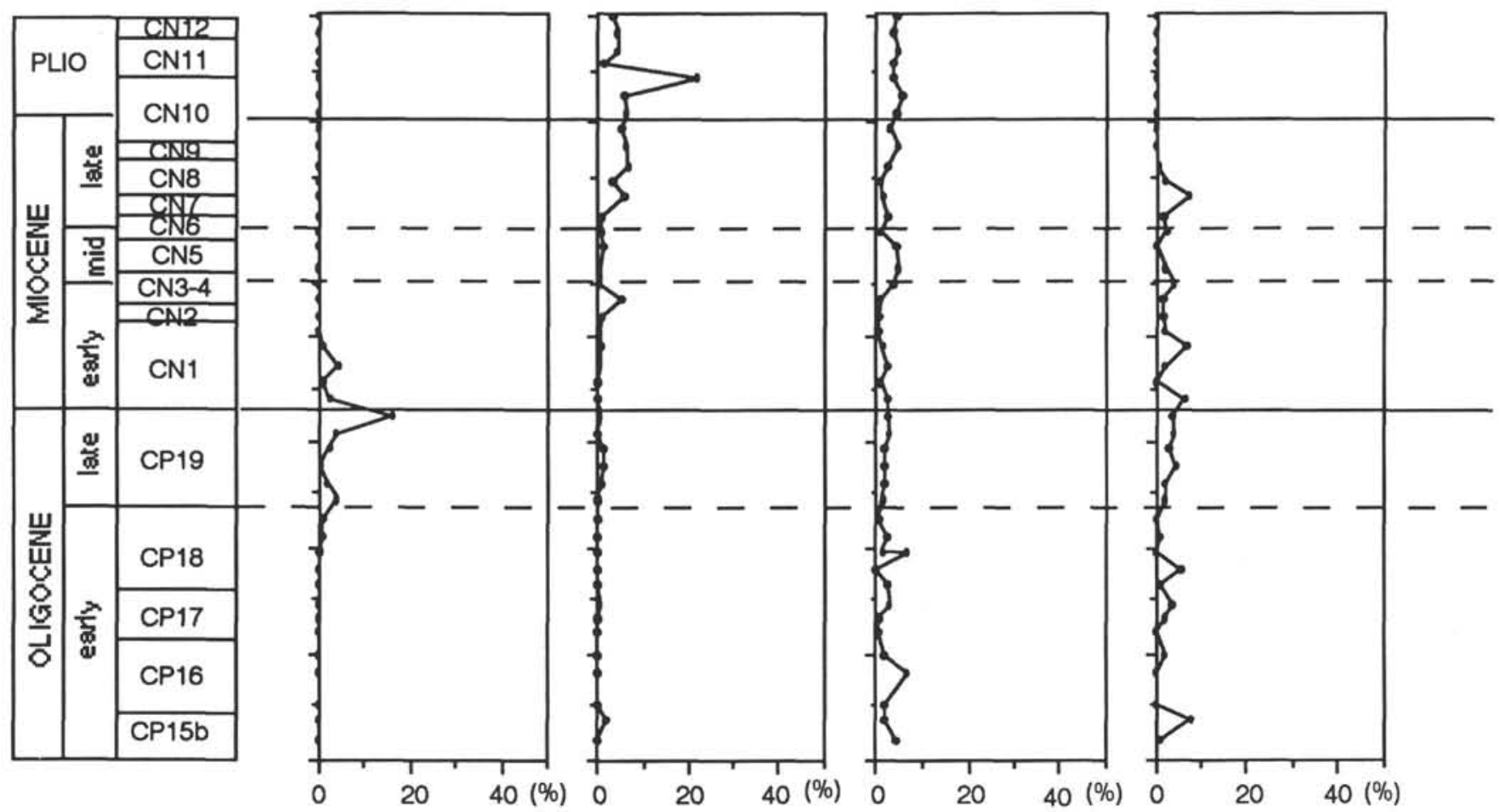

Globocassidulina subglobosa (s.l.) Epistominella umbonifera Cibicidoides mundulus

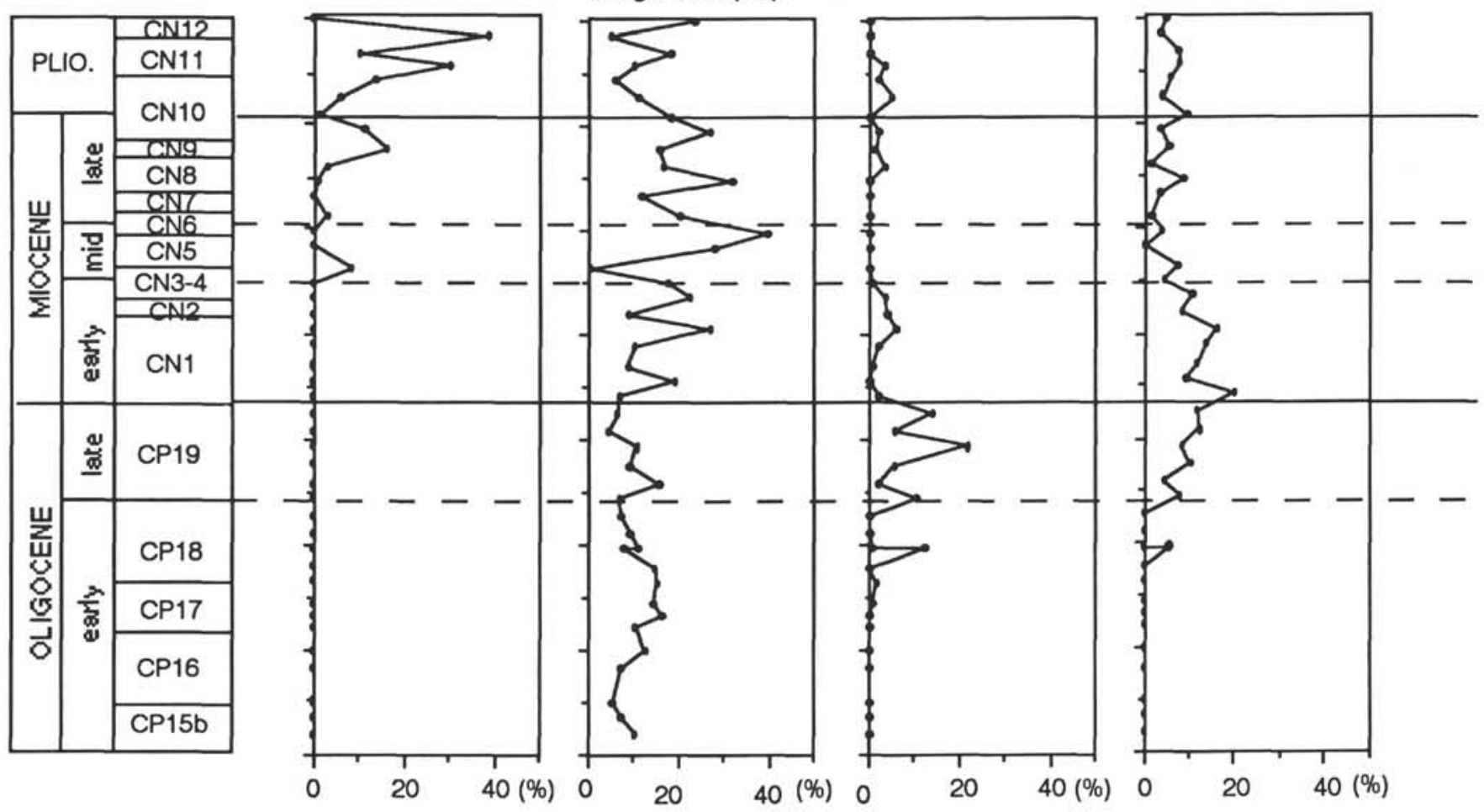

Figure 7. Relative abundance of selected benthic foraminifers plotted vs. sub-bottom depth and referred to nannofossil zone. 

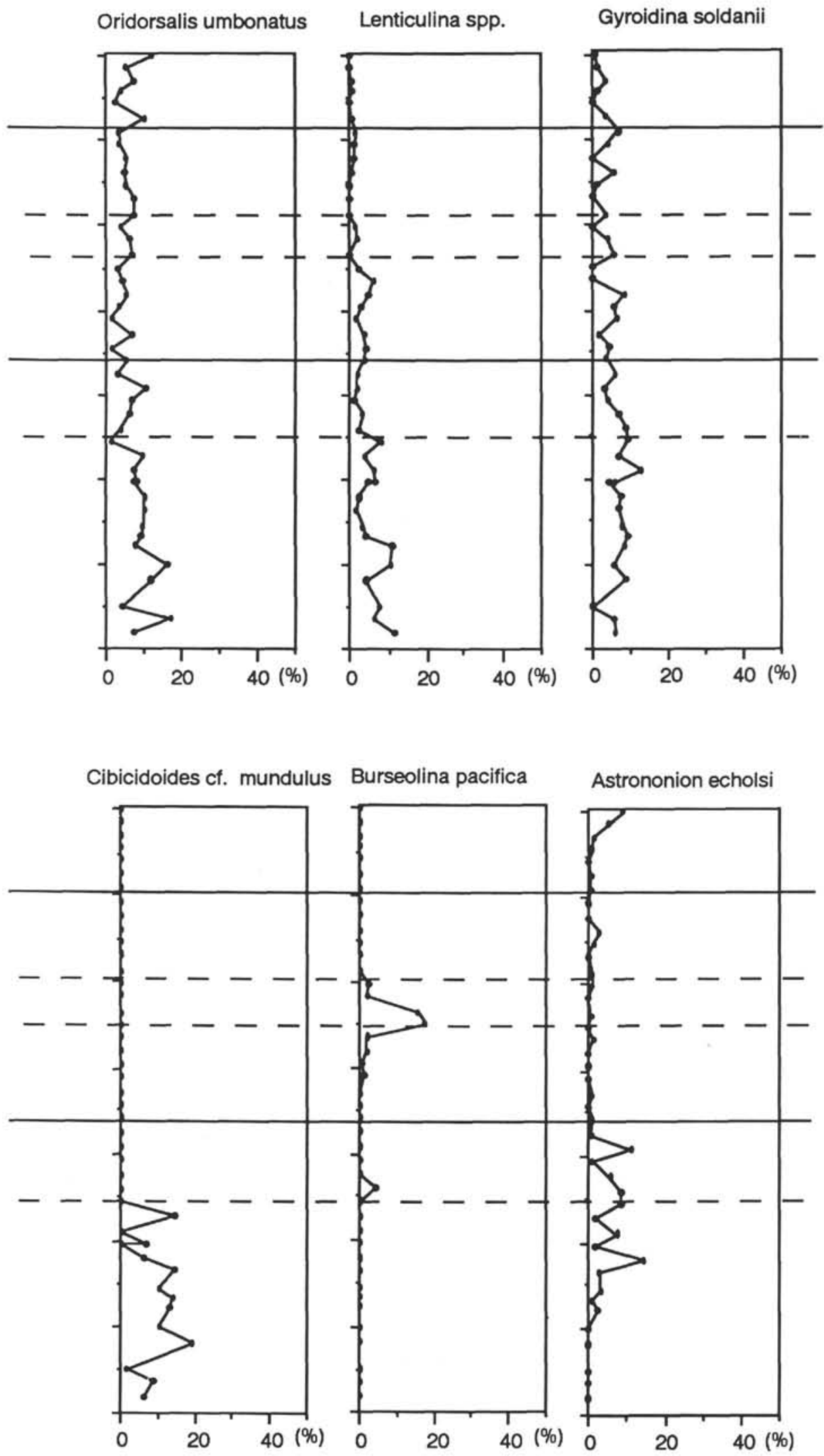

Figure 7 (continued). 


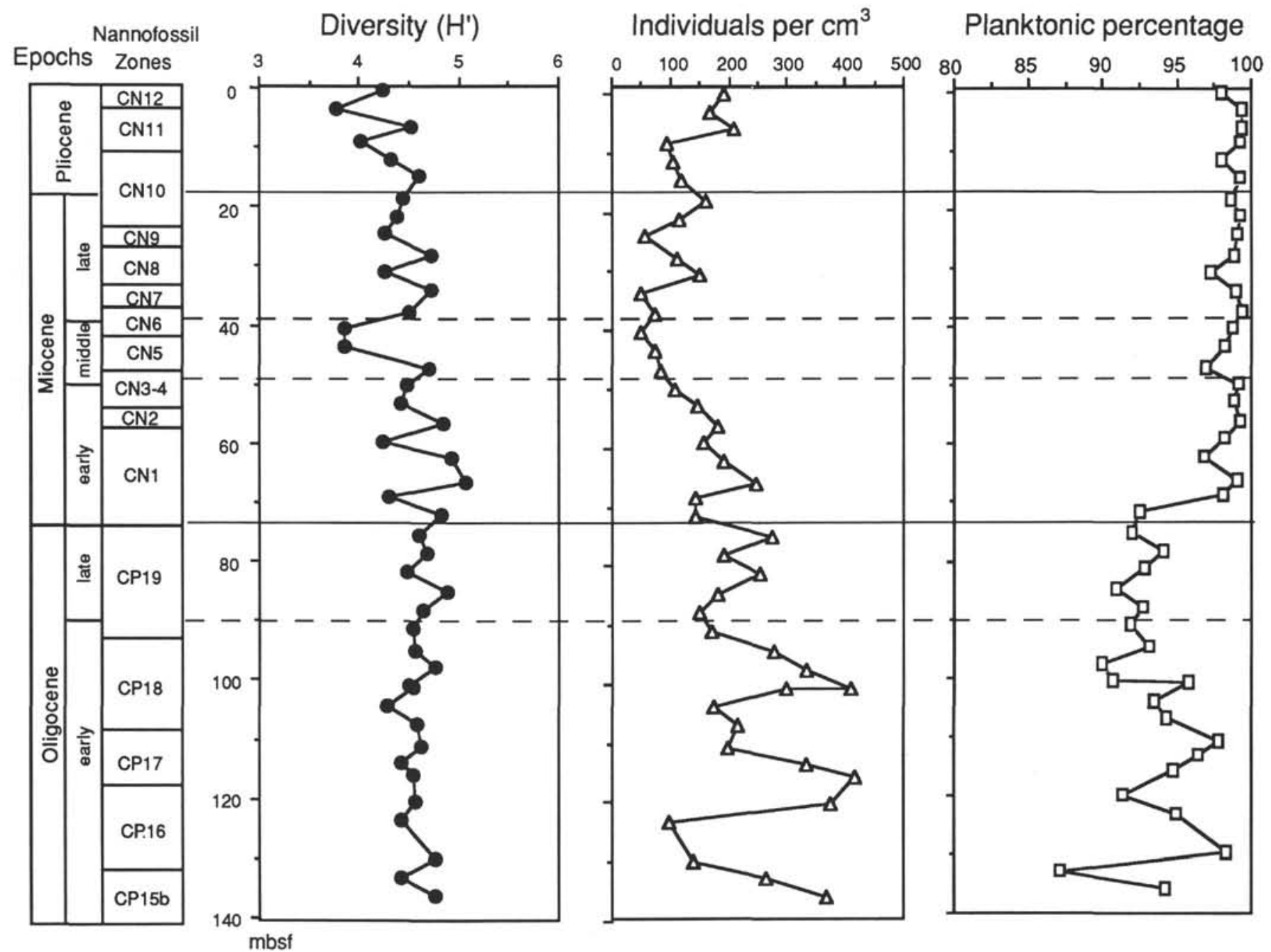

Figure 8. Species diversity, foraminifer number $/ \mathrm{cm}^{3}$, and planktonic to benthic percentages plotted vs. sub-bottom depth and referred to nannofossil zones. 
Table 3. Varimax factor loadings from factor analysis of Site 754.

\begin{tabular}{|c|c|c|c|c|c|c|c|c|c|}
\hline Section & terval $(\mathrm{cm})$ & Communality & Factor 1 & Factor 2 & Factor 3 & Factor 4 & Factor 5 & Factor 6 & Factor 7 \\
\hline $754 \mathrm{~A}-1 \mathrm{H}-1$ & 70.75 & 0.9100 & 0.8943 & 0.0723 & 0.1783 & -0.0034 & 0.0611 & .0 .0314 & 0.2617 \\
\hline $754 \mathrm{~A}-1 \mathrm{H}-3$ & 70.75 & 0.9175 & 0.0922 & 0.0083 & 0.0752 & 0.0162 & 0.0179 & 0.0102 & 0.9501 \\
\hline $754 \mathrm{~A}-2 \mathrm{H}-1$ & 70.75 & 0.6359 & 0.0122 & -0.1168 & 0.2000 & 0.7342 & 0.1095 & 0.1629 & 0.0670 \\
\hline $754 \mathrm{~A}-2 \mathrm{H}-3$ & 70.75 & 0.6383 & 0.1145 & 0.0925 & 0.1275 & 0.7715 & 0.0227 & 0.0265 & 0.0626 \\
\hline $754 \mathrm{~A} \cdot 3 \mathrm{H} \cdot 1$ & 70.75 & 0.7099 & 0.1979 & 0.1568 & 0.0493 & 0.7760 & 0.1089 & -0.1569 & -0.0713 \\
\hline $754 \mathrm{~A}-3 \mathrm{H}-5$ & $70-75$ & 0.9132 & 0.4042 & 0.2181 & 0.4539 & 0.3238 & 0.0326 & .0 .0667 & 0.6212 \\
\hline $754 \mathrm{~A}-4 \mathrm{H}-1$ & 70.75 & 0.8386 & 0.5877 & -0.0173 & 0.6543 & 0.0348 & .0 .0238 & 0.0310 & 0.2491 \\
\hline $754 \mathrm{~A} \cdot 4 \mathrm{H} \cdot 5$ & 70.75 & 0.8369 & 0.8073 & 0.0594 & 0.2508 & 0.1535 & 0.2087 & -0.0389 & 0.2237 \\
\hline $754 \mathrm{~A}-5 \mathrm{H}-1$ & $70-75$ & 0.5 & 0.5691 & 0.0358 & 0.2386 & 0.3060 & 0.1490 & 0.1124 & 0.0298 \\
\hline $754 \mathrm{~A} \cdot 5 \mathrm{H} \cdot 5$ & 70.75 & 0.8190 & 0.8248 & -0.0108 & 0.0598 & 0.2748 & 0.1184 & 0.2129 & 0.0119 \\
\hline $754 \mathrm{~A}-6 \mathrm{H}-1$ & $70-75$ & 34 & 0.6872 & 0.2224 & 0.0872 & 0.5693 & 0.0801 & -0.0564 & -0.0178 \\
\hline $754 \mathrm{~A}$ & 70.75 & 0.6 & 0.3066 & 0.1329 & 0.6051 & 0.3856 & 0.0384 & 0.0466 & 0.1170 \\
\hline $754 \mathrm{~A}$ & 70.75 & 0.6832 & 0.1381 & 0.2681 & 0.7282 & 0.1631 & 0.1813 & -0.0241 & 0.0430 \\
\hline $754 \mathrm{~A}-7 \mathrm{H}-3$ & 70.75 & 0.8572 & 0.7470 & 0.1294 & 0.4806 & 0.0852 & 0.2053 & -0.0231 & 0.0387 \\
\hline $754 \mathrm{~A}$. & 70.75 & 29 & 0.2213 & 253 & 671 & 0.2232 & 0.0831 & -0.1407 & 0.1148 \\
\hline $754 \mathrm{~A}$ & 70.75 & 32 & -0.0605 & 0.0858 & 0.8575 & 0.0936 & 283 & 198 & -0.0043 \\
\hline $754 \mathrm{~A}-$ & 70.75 & 0.8 & 0.4804 & 0.0466 & 674 & -0.0506 & 177 & 0.0924 & 0.0097 \\
\hline $754 \mathrm{~A} \cdot 8 \mathrm{H} \cdot 5$ & 70.75 & 0.5 & 0.4005 & 0.5446 & 0.2754 & -0.1650 & 0.0558 & 0.1860 & -0.0384 \\
\hline $754 \mathrm{~A}-9 \mathrm{H}-1$ & 70.75 & 0.7367 & 0.2729 & 0.3270 & 0.2963 & 0.0552 & 0.6802 & 0.0088 & -0.0407 \\
\hline $754 \mathrm{~A}-9 \mathrm{H}-3$ & 70.75 & 0.7778 & -0.0 & 63 & 15 & 0.1041 & 0.6206 & 0.2530 & 0.0306 \\
\hline $754 \mathrm{~A}$ & 70.75 & 0.8 & -0.0152 & 124 & 19 & 0.2802 & 245 & 0.2836 & -0.0256 \\
\hline 754 A. & 70.75 & & 0.6786 & 0.4742 & 0.1596 & 0.0938 & 0.4134 & 0.0674 & -0.0287 \\
\hline $754 \mathrm{~A}-10 \mathrm{H}-5$ & 70.75 & 0.9103 & -0.0088 & 0.9045 & 0.1741 & 0.1740 & 0.1609 & 0.0481 & 0.0582 \\
\hline $754 \mathrm{~A}$ & 70.75 & 49 & 031 & 0.8658 & 23 & 0.0479 & 0.3795 & 0.0922 & 0.0151 \\
\hline $754 \mathrm{~A}$. & 70.75 & 0.8 & 0.1904 & 0.7857 & 393 & 0.1433 & 0.3672 & -0.1966 & 0.0879 \\
\hline $754 \mathrm{~A}$. & 70.75 & 48 & 0.4520 & 0.1385 & 0.1249 & -0.0066 & 0.7166 & -0.2051 & -0.0091 \\
\hline $754 \mathrm{~A}-12 \mathrm{H}-3$ & 70.75 & 0.8283 & 0.4793 & 0.1422 & -0.0187 & -0.0616 & 0.7467 & -0.1291 & -0.0011 \\
\hline $754 \mathrm{~A}-12 \mathrm{H}-5$ & 70.75 & 0.6821 & 0.2058 & 0.1824 & 0.0960 & 0.0536 & 0.7692 & 0.0039 & 0.0524 \\
\hline $754 \mathrm{~A}$ & & 0.7 & 0.0457 & 0.0528 & -0.0439 & 0.0330 & 0.0347 & 0.8545 & 0.0110 \\
\hline $754 A-13 X-3$ & 70.75 & 14 & 0.7857 & 0.0176 & 0.1057 & -0.0046 & 0.4778 & -0.1082 & -0.0508 \\
\hline \multirow{2}{*}{\multicolumn{3}{|c|}{$\begin{array}{l}\text { Variance } \\
\text { Cumulative variance }\end{array}$}} & 20.956 & 12.063 & 14.385 & 9.309 & 13.55 & 3.956 & 5.122 \\
\hline & & & 20.956 & 33.019 & 47.405 & 56.714 & 70.263 & 74.219 & 79.341 \\
\hline
\end{tabular}


Table 4. Factor score matrix from varimax factor analysis of Site $\mathbf{7 5 4}$.

\begin{tabular}{|c|c|c|c|c|c|c|c|}
\hline Taxa & Factor 1 & Factor 2 & Factor 3 & Factor 4 & Factor 5 & Factor 6 & Factor 7 \\
\hline Astrononion echolsi & .0 .023 & -0.010 & .0 .022 & 0.253 & -0.010 & -0.014 & 0.056 \\
\hline Brizalina albatrossi & 0.062 & 0.015 & 0.151 & 0.084 & .0 .044 & 0.063 & -0.093 \\
\hline Bulimina mexicana & 0.060 & .0 .020 & .0 .010 & 0.244 & -0.055 & 0.067 & -0.020 \\
\hline Bulimina rostrata & -0.028 & 0.007 & 0.116 & -0.016 & 0.000 & -0.017 & -0.032 \\
\hline Bulimina tuxpamensis & 0.079 & .0 .029 & -0.094 & -0.077 & 0.316 & -0.204 & -0.005 \\
\hline Burseolina cf. pacifica & 0.014 & 0.660 & -0.082 & -0.117 & .0 .002 & 0.160 & -0.048 \\
\hline Burseolina pacifica & -0.191 & 0.058 & 0.405 & -0.014 & 0.147 & 0.044 & -0.092 \\
\hline Cibicides ? sp. & -0.016 & .0 .058 & -0.023 & -0.001 & 0.162 & -0.017 & 0.030 \\
\hline Cibicides lobatulus & 0.129 & .0 .036 & .0 .018 & 0.106 & -0.037 & 0.097 & 0.111 \\
\hline Cibicidoides cl.mundulus & 0.027 & .0 .092 & .0 .050 & -0.018 & 0.242 & -0.019 & 0.007 \\
\hline Cibicidoides mundulus & 0.017 & 0.648 & 0.050 & 0.233 & -0.186 & -0.241 & 0.145 \\
\hline Dentalina communis & -0.048 & 0.028 & 0.035 & 0.009 & 0.123 & 0.061 & -0.001 \\
\hline Ehrenbergina spp. & 0.015 & .0 .031 & -0.077 & .0 .029 & 0.037 & 0.008 & 0.922 \\
\hline Epistominella umbonifera & -0.032 & 0.128 & -0.014 & -0.019 & 0.110 & 0.052 & 0.025 \\
\hline Gaudryina spp. & 0.033 & -0.007 & 0.009 & 0.051 & 0.009 & -0.022 & 0.005 \\
\hline Gavelinopsis lobatulus & 0.005 & .0 .022 & -0.111 & 0.649 & 0.007 & -0.104 & -0.123 \\
\hline Globocassidulina reflexa & .0 .030 & .0 .040 & 0.016 & 0.120 & 0.024 & 0.002 & -0.013 \\
\hline Globocassidulina spp. & 0.933 & 0.002 & -0.017 & -0.049 & 0.107 & -0.035 & -0.046 \\
\hline Gyroidina orbicularis & 0.068 & .0 .024 & .0 .023 & 0.045 & -0.003 & 0.689 & -0.004 \\
\hline Gyroidina soldanii & 0.020 & 0.053 & 0.092 & 0.035 & 0.062 & -0.002 & 0.008 \\
\hline Karreriella bradyi & 0.060 & .0 .035 & 0.130 & 0.334 & 0.008 & 0.006 & 0.123 \\
\hline Laticarina pauperata & 0.003 & -0.032 & 0.138 & 0.094 & 0.033 & -0.009 & 0.111 \\
\hline Lenticulina spp. & -0.100 & 0.119 & 0.033 & -0.059 & 0.668 & 0.023 & 0.030 \\
\hline Nonion havanensis & 0.009 & 0.026 & 0.054 & -0.044 & 0.033 & 0.028 & -0.044 \\
\hline Oridorsalis umbonatus & 0.104 & 0.115 & 0.112 & 0.202 & 0.163 & 0.094 & 0.013 \\
\hline Orthomorphina antillea & 0.009 & .0 .001 & -0.004 & 0.012 & 0.033 & 0.018 & 0.020 \\
\hline Orthomorphina cf. antillea & 0.040 & 0.086 & 0.026 & -0.016 & -0.038 & 0.036 & -0.016 \\
\hline Orthomorphina himerensis & 0.033 & .0 .035 & 0.034 & 0.064 & 0.013 & 0.036 & 0.004 \\
\hline Planulina dohertyi & -0.011 & 0.061 & -0.027 & -0.008 & 0.185 & 0.011 & -0.015 \\
\hline Planulina wuellerstorfi & 0.086 & .0 .068 & 0.727 & -0.111 & -0.173 & 0.037 & 0.152 \\
\hline Pullenia bulloides & 0.053 & 0.046 & 0.341 & 0.072 & 0.226 & .0 .130 & -0.085 \\
\hline Rectuvigerina striata & -0.019 & 0.131 & -0.044 & .0 .008 & 0.067 & 0.507 & 0.026 \\
\hline Sphaeroidina bulloides & -0.010 & 0.029 & -0.055 & 0.004 & 0.239 & -0.082 & 0.040 \\
\hline Stilostomella cf. annulifera & -0.023 & 0.019 & 0.064 & -0.016 & 0.102 & -0.017 & 0.008 \\
\hline Stilostomella lepidula & -0.035 & 0.052 & 0.132 & 0.072 & 0.117 & -0.072 & 0.017 \\
\hline Textularia milletti & -0.011 & -0.011 & 0.048 & 0.044 & 0.003 & 0.022 & 0.012 \\
\hline Trifarina bradyi & 0.073 & 0.088 & 0.080 & .0 .102 & .0 .084 & 0.092 & -0.082 \\
\hline Uvigerina proboscidea & .0 .051 & -0.122 & 0.051 & 0.361 & 0.132 & 0.218 & 0.023 \\
\hline Uvigerina schencki & 0.019 & 0.001 & 0.102 & -0.014 & -0.026 & -0.038 & .0 .020 \\
\hline Uvigerina sp. A & 0.027 & -0.014 & 0.009 & 0.015 & -0.008 & 0.025 & -0.008 \\
\hline Vulvulina spinosa & -0.012 & 0.088 & .0 .012 & -0.004 & 0.047 & -0.008 & 0.004 \\
\hline Valvulineria laevigata & 0.017 & 0.047 & 0.029 & -0.035 & 0.035 & 0.023 & -0.036 \\
\hline
\end{tabular}


Table 5. Varimax factor loadings from factor analysis of Site $\mathbf{7 5 6}$.

\begin{tabular}{|c|c|c|c|c|c|c|c|c|}
\hline Section & Intervals $(\mathrm{cm})$ & Communality & Factor 1 & Factor 2 & Factor 3 & Factor 4 & Factor 5 & Factor 6 \\
\hline $756 \mathrm{~B}-1 \mathrm{H}-1$ & 70.75 & 0.8354 & 0.7782 & 0.3206 & 0.2325 & 0.1290 & -0.0519 & 0.1486 \\
\hline $756 \mathrm{~B} \cdot 1 \mathrm{H} \cdot 3$ & 70.75 & 0.9128 & 0.1229 & 0.0365 & 0.0207 & 0.9124 & -0.0721 & 0.2412 \\
\hline $756 \mathrm{~B} \cdot 1 \mathrm{H} \cdot 5$ & 70.75 & 0.9318 & 0.7138 & 0.2353 & 0.2701 & 0.4765 & 0.0439 & 0.2547 \\
\hline $756 \mathrm{~B} \cdot 2 \mathrm{H} \cdot 1$ & $70-75$ & 0.8696 & 0.2838 & 0.0324 & 0.1470 이 & 0.8480 & 0.0192 & 0.2165 \\
\hline $756 \mathrm{~B}-2 \mathrm{H}-3$ & 70.75 & 0.8473 & 0.2486 & -0.0277 & 0.1270 & 0.4938 & 0.0226 & 0.7241 \\
\hline $756 \mathrm{~B}-2 \mathrm{H} \cdot 5$ & 70.75 & 0.8377 & 0.5062 & 0.3134 & 0.3764 & 0.3452 & .0 .0099 & 0.4716 \\
\hline $756 \mathrm{~B} \cdot 3 \mathrm{H} \cdot 1$ & 70.75 & 0.8883 & 0.7655 & 0.2319 & 0.3651 & 0.1611 & 0.1773 & 0.2404 \\
\hline $756 \mathrm{~B} \cdot 3 \mathrm{H} \cdot 3$ & 70.75 & 0.9420 & 0.8295 & 0.2266 & 0.1768 & 0.3446 & .0 .0423 & 0.2252 \\
\hline $756 \mathrm{~B} \cdot 3 \mathrm{H} \cdot 5$ & 70.75 & 0.7863 & 0.2216 & 0.0539 & 0.0852 & 0.2188 & 0.0138 & 0.8240 \\
\hline $756 \mathrm{~B} \cdot 4 \mathrm{H} \cdot 1$ & 70.75 & 0.8763 & 0.7566 & 0.2773 & 0.2813 & 0.1682 & .0 .1407 & 0.3158 \\
\hline $756 \mathrm{~B} \cdot 4 \mathrm{H} \cdot 3$ & 70.75 & 0.9624 & 0.9107 & 0.2147 & 0.2519 & 0.0714 & 0.0754 & 0.1128 \\
\hline $756 \mathrm{~B} \cdot 4 \mathrm{H} \cdot 5$ & 70.75 & 0.7310 & 0.6625 & 0.2636 & 0.2348 & 0.0898 & 0.2192 & 0.3337 \\
\hline $756 \mathrm{~B} \cdot 5 \mathrm{H} \cdot 1$ & 70.75 & 0.8656 & 0.8215 & 0.3297 & 0.1838 & 0.1748 & .0 .0823 & 0.1043 \\
\hline $756 \mathrm{~B} \cdot 5 \mathrm{H} \cdot 3$ & 70.75 & 0.9465 & 0.9326 & 0.2373 & 0.1428 & 0.0044 & 0.0073 & 0.0042 \\
\hline $756 \mathrm{~B} \cdot 5 \mathrm{H} \cdot 5$ & 70.75 & 0.9408 & 0.8885 & 0.3522 & 0.1356 & 0.0477 & -0.0206 & 0.0784 \\
\hline $756 \mathrm{~B} \cdot 6 \mathrm{H}-1$ & 70.75 & 0.7059 & 0.1003 & 0.1648 & 0.2637 & 0.6488 & 0.4207 & .0 .0343 \\
\hline $756 \mathrm{~B} \cdot 6 \mathrm{H} \cdot 3$ & 70.75 & 0.6608 & 0.6762 & 0.2021 & 0.1798 & 0.1851 & 0.2941 & .0 .0981 \\
\hline $756 \mathrm{~B} \cdot 6 \mathrm{H} \cdot 5$ & 70.75 & 0.9157 & 0.7873 & 0.2379 & 0.4132 & 0.0458 & 0.2089 & 0.1509 \\
\hline $756 \mathrm{~B} \cdot 7 \mathrm{H} \cdot 1$ & 70.75 & 0.8774 & 0.4624 & 0.3696 & 0.6528 & 0.1507 & 0.2795 & .0 .0009 \\
\hline $756 \mathrm{~B} \cdot 7 \mathrm{H}-3$ & $70-75$ & 0.9281 & 0.7737 & 0.1878 & 0.4934 & 0.0523 & 0.2186 & 0.0136 \\
\hline $756 \mathrm{~B} \cdot 7 \mathrm{H} \cdot 5$ & 70.75 & 0.8681 & 0.4973 & 0.1414 & 0.6355 & 0.1411 & 0.4203 & .0 .0196 \\
\hline $756 \mathrm{~B} \cdot 8 \mathrm{H} \cdot 1$ & 70.75 & 0.7989 & 0.4224 & 0.2627 & 0.5850 & 0.1268 & 0,4365 & 0,0513 \\
\hline $756 \mathrm{~B} \cdot 8 \mathrm{H} \cdot 3$ & 70.75 & 0.7720 & 0.6721 & 0.2504 & 0.3335 & 0.0198 & 0.3806 & 0.0338 \\
\hline $756 \mathrm{~B}-8 \mathrm{H}-5$ & 70.75 & 0.8883 & 0.2754 & $0.13: 2$ & 0.7319 & 0.1372 & 0.4901 & 0.0214 \\
\hline $756 \mathrm{~B} \cdot 9 \mathrm{H} \cdot 1$ & 70.75 & 0.7453 & 0.1462 & 0.0720 & 0.8401 & 0.0287 & 0.0605 & 0.0924 \\
\hline $756 \mathrm{~B} \cdot 9 \mathrm{H} \cdot 3$ & 70.75 & 0.7738 & 0.1727 & 0.2520 & 0.7996 & 0.2001 & 0.0316 & 0.0138 \\
\hline $756 \mathrm{~B} \cdot 9 \mathrm{H} \cdot 5$ & 70.75 & 0.7872 & 0.2737 & 0.1923 & 0.7919 & .0 .0082 & -0.0653 & 0.2096 \\
\hline $756 \mathrm{~B}-10 \mathrm{H} \cdot 1$ & 70.75 & 0.9078 & 0.3837 & 0.3548 & 0.7757 & 0.1364 & 0.1172 & 0.0259 \\
\hline $756 \mathrm{~B} \cdot 10 \mathrm{H} \cdot 3$ & 70.75 & 0.8147 & 0.6278 & 0.3551 & 0.4963 & 0.1599 & -0.0842 & .0 .1241 \\
\hline $756 \mathrm{~B} \cdot 1 \mathrm{OH} \cdot 5$ & 70.75 & 0.8339 & 0.1836 & 0.3444 & 0.8126 & 0.0893 & -0.0879 & .0 .0745 \\
\hline $756 \mathrm{~B}-11 \mathrm{H}-1$ & 70.75 & 0.9024 & 0.1251 & 0.9224 & 0.1697 & 0.0815 & 0.0200 & .0 .0018 \\
\hline $756 \mathrm{~B}-11 \mathrm{H}-3$ & 70.75 & 0.7307 & 0.3200 & 0.6344 & 0.4094 & 0.1605 & .0 .1230 & .0 .1317 \\
\hline $756 \mathrm{~B} \cdot 11 \mathrm{H} \cdot 5$ & 70.75 & 0.7852 & 0.3664 & 0.7697 & 0.2226 & 0.0825 & -0.0354 & .0 .0309 \\
\hline $756 C \cdot 4 X \cdot 1$ & 70.75 & 0.7918 & 0.2330 & 0.3677 & 0.7213 & 0.0217 & -0.0404 & 0.2828 \\
\hline $756 C \cdot 4 X-3$ & 70.75 & 0.7829 & 0.4558 & 0.6082 & 0.3203 & 0,1646 & -0.2310 & $.0,1487$ \\
\hline $756 C .4 \times-5$ & 70.75 & 0.8553 & 0.4390 & 0.7810 & 0.1979 & 0.0876 & -0.0751 & 0.0083 \\
\hline $756 C \cdot 5 x \cdot 2$ & 65.70 & 0.8977 & 0.4747 & 0.7825 & 0.2210 & 0.1048 & -0.0155 & 0.0088 \\
\hline $756 C \cdot 5 \times-5$ & 70.75 & 0.9041 & 0.4650 & 0.8064 & 0.1673 & 0.0776 & .0 .0434 & .0 .0415 \\
\hline $756 C \cdot 5 x \cdot 7$ & 70.75 & 0.8912 & 0.1959 & C. 8965 & 0.2010 & 0.0318 & 0.0855 & 0.0199 \\
\hline $756 C-6 \times-1$ & 70.75 & 0.8223 & 0.2309 & 0.8371 & 0.1808 & 0.0224 & 0.1445 & 0.1192 \\
\hline $756 C \cdot 6 \times \cdot 3$ & 70.75 & 0.8711 & 0.0895 & 0.9087 & 0.1245 & 0.0891 & 0.0304 & 0.1134 \\
\hline $756 C-7 X-1$ & 70.75 & 0.6834 & 0.2628 & 0.6543 & 0.1355 & -0.0464 & 0.3748 & 0.1590 \\
\hline $756 C \cdot 7 \times-3$ & 70.75 & 0.5642 & 0.1133 & 0.6962 & 0.1549 & 0.0778 & 0.1405 & 0.1300 \\
\hline $756 C-7 \times-5$ & 70.75 & 0.8842 & 0.3071 & 0.8263 & 0.2022 & 0.0203 & 0.2306 & 0.1126 \\
\hline \multirow{2}{*}{\multicolumn{3}{|c|}{$\begin{array}{l}\text { Variance } \\
\text { Cumulative variance }\end{array}$}} & 27.284 & 22.591 & 17.62 & 7.195 & 3.795 & 5.191 \\
\hline & & & 27.284 & 49.875 & 67.495 & 74.69 & 78.485 & 83.676 \\
\hline
\end{tabular}




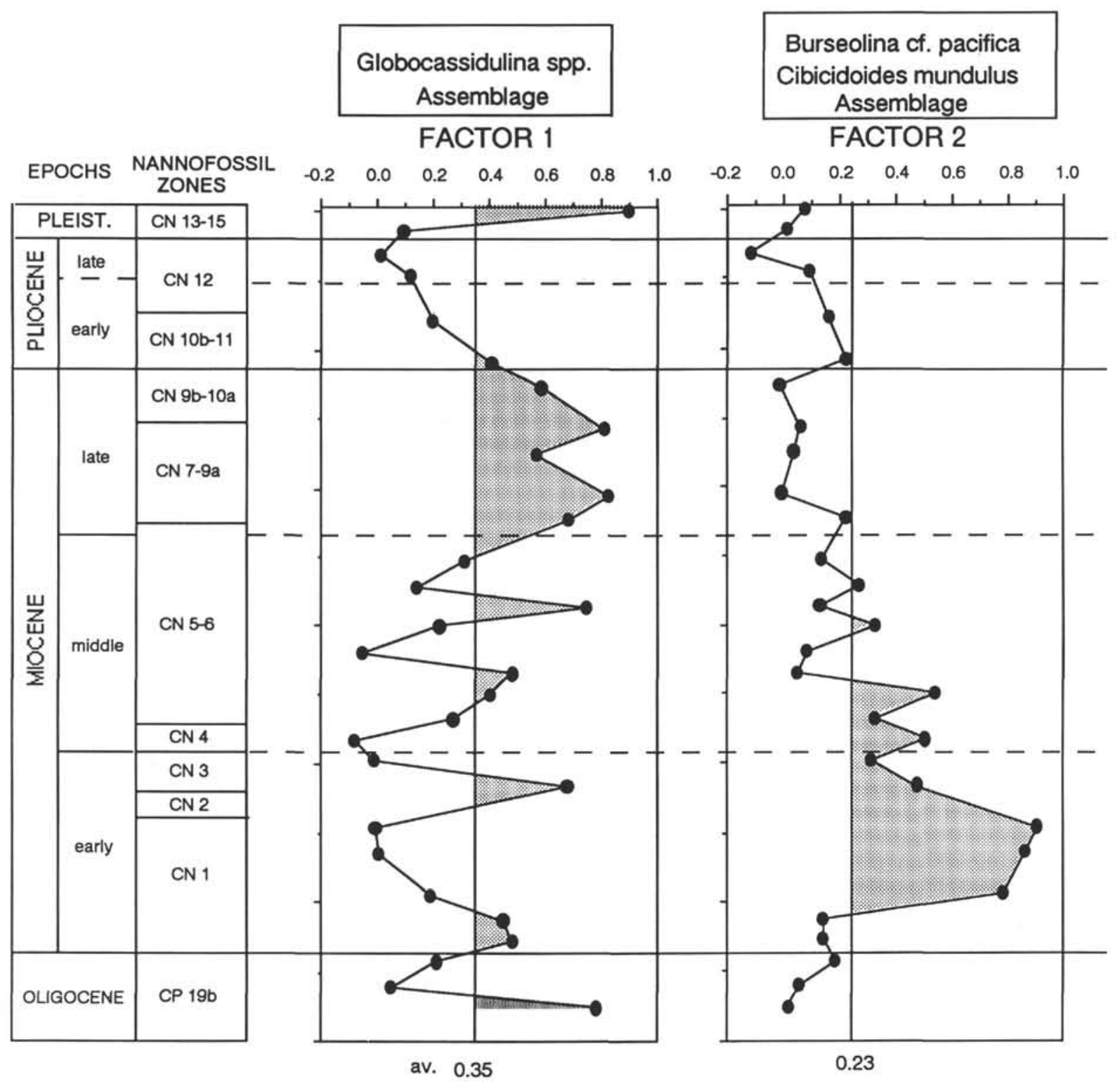

Figure 9. Factor loading vs. sub-bottom depth and referred to nannofossil zones at Site 754. 


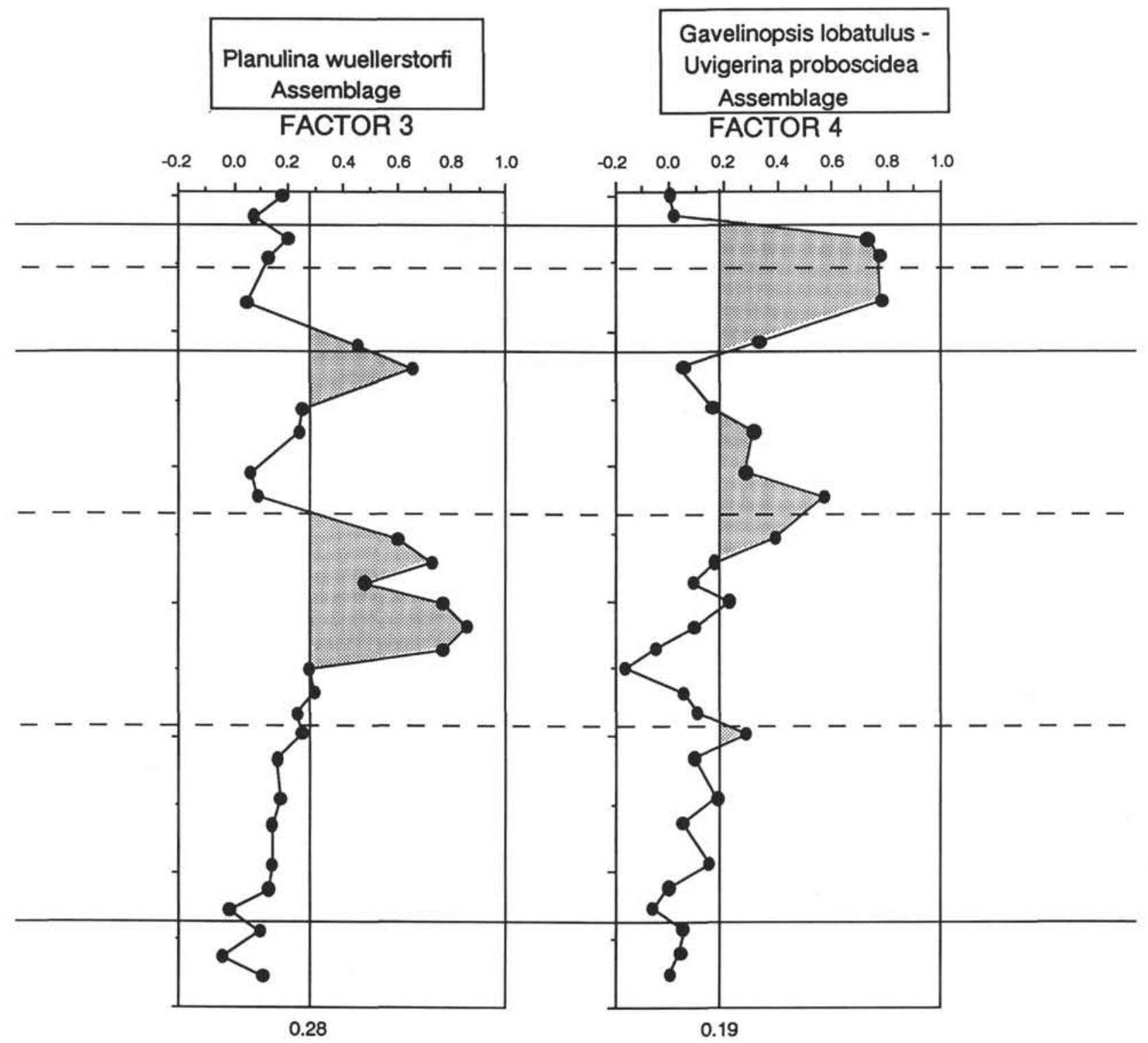

Figure 9 (continued). 


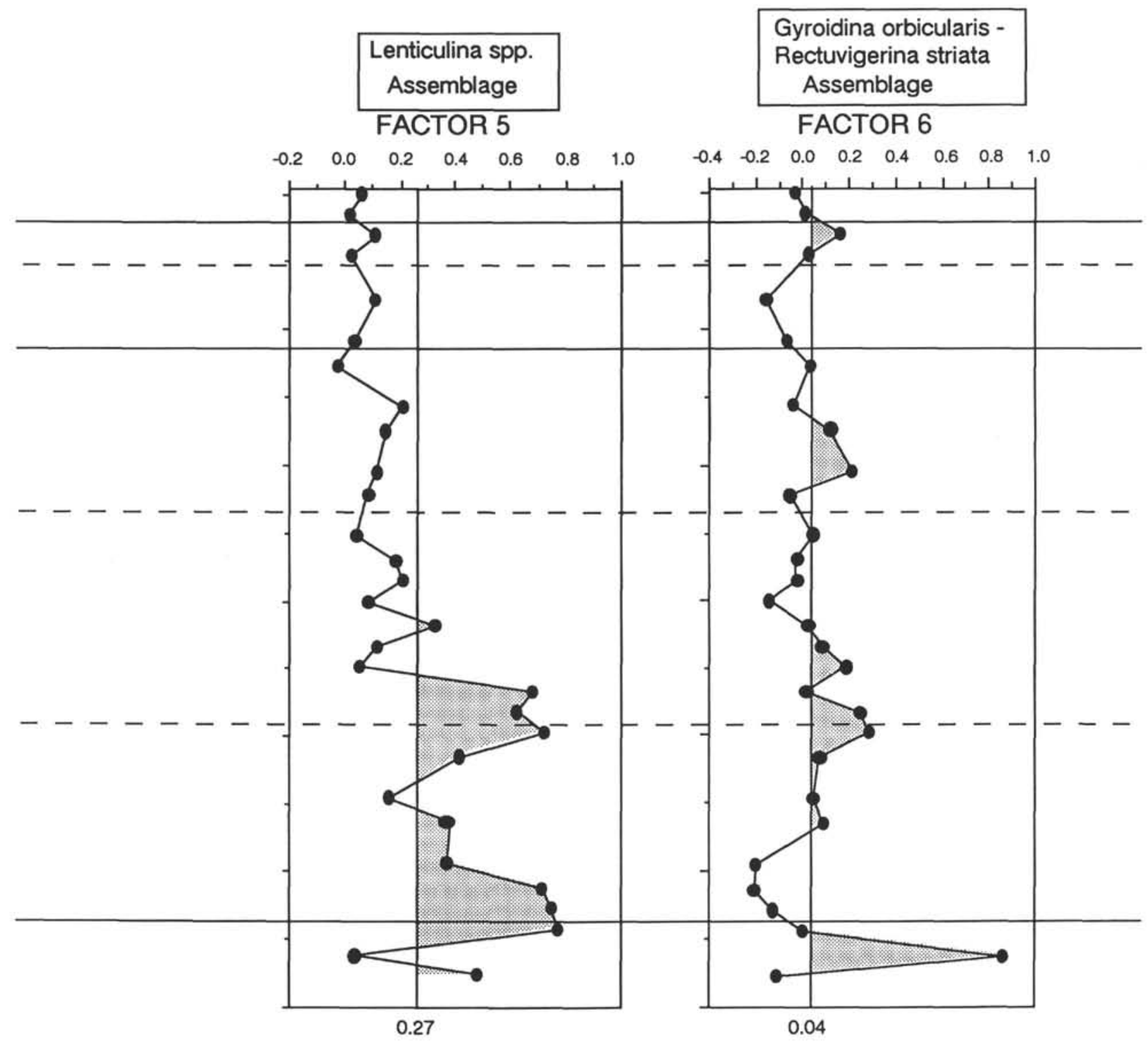

Figure 9 (continued). 


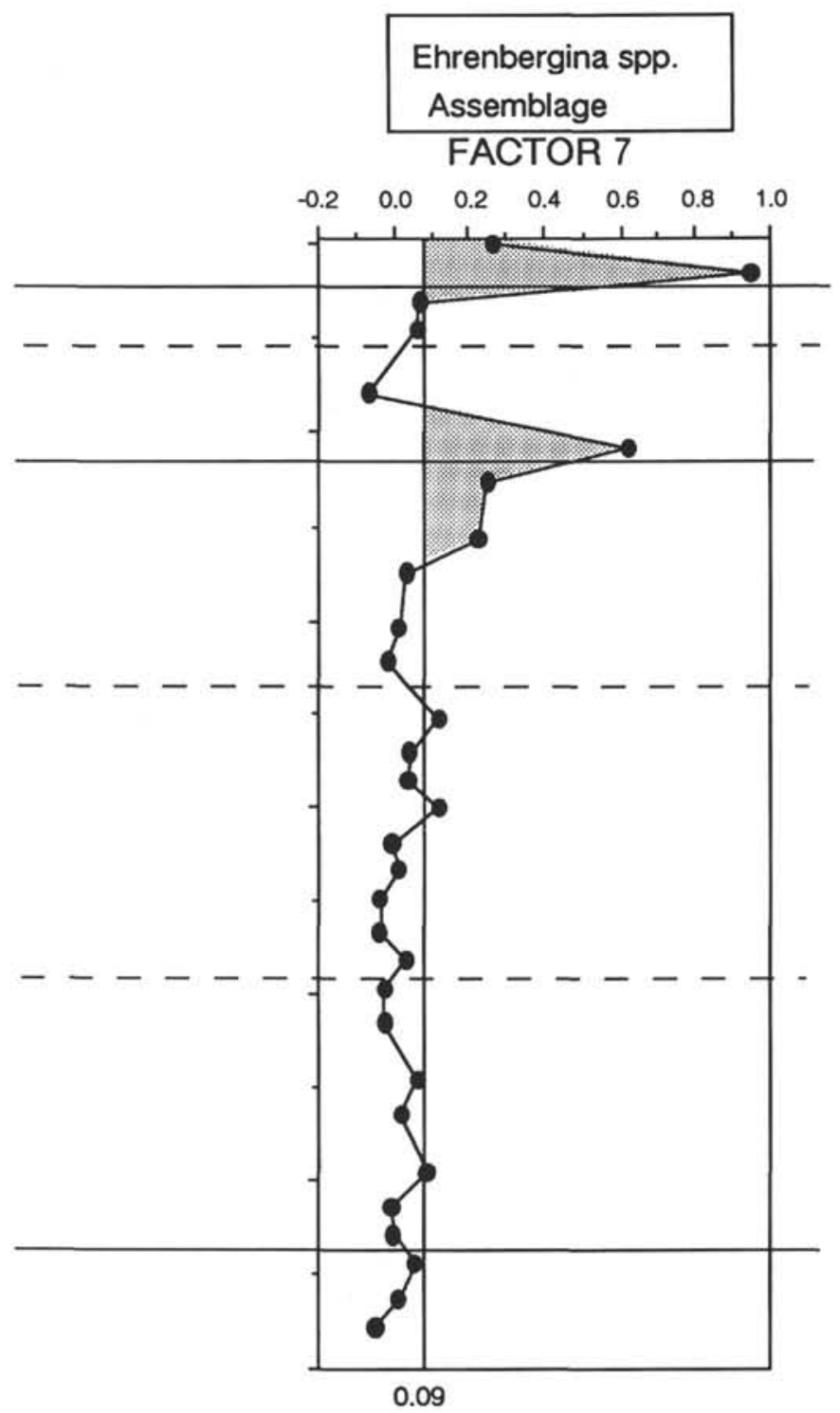

Figure 9 (continued). 


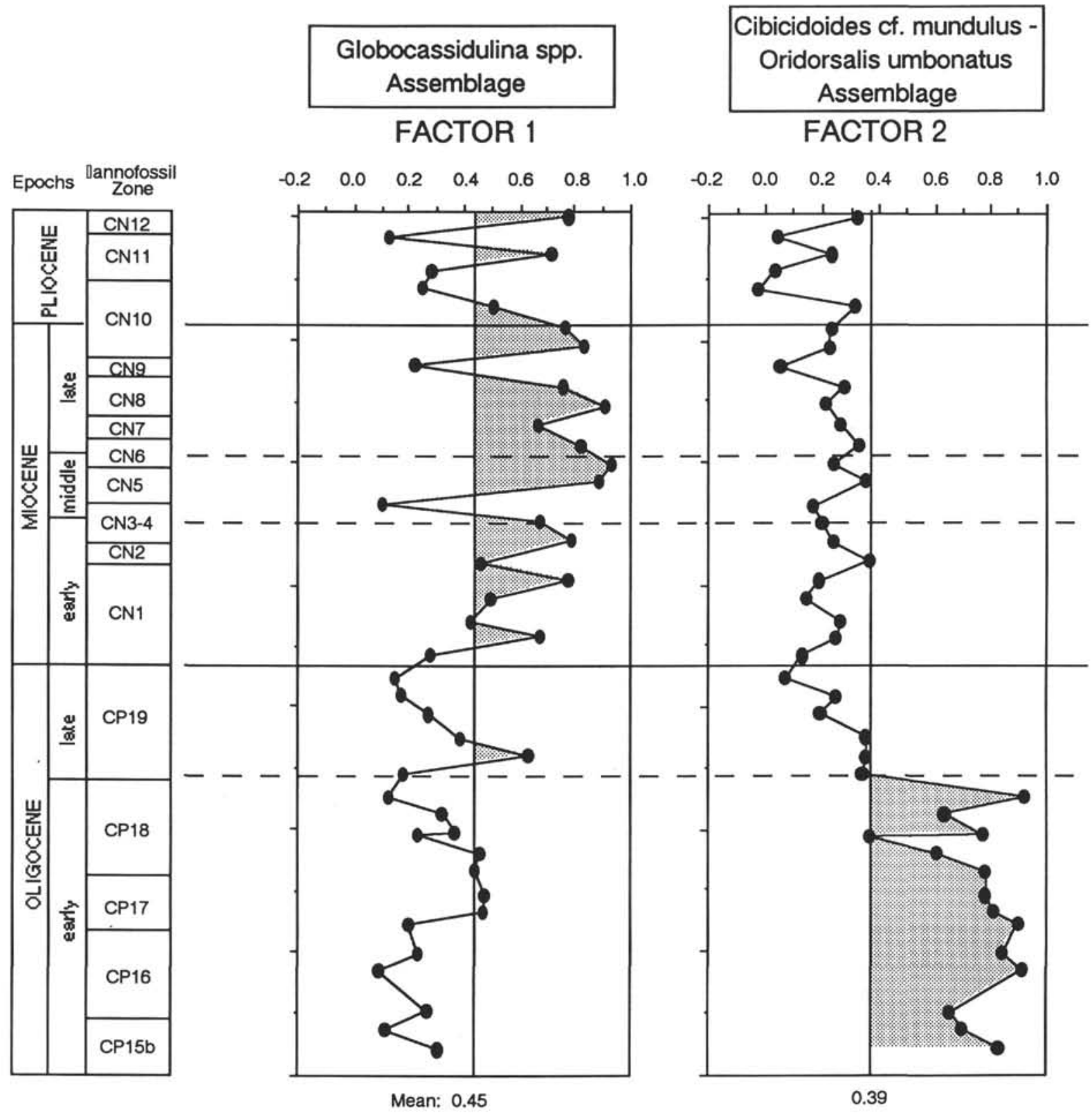

Figure 10. Factor loading plotted vs. sub-bottom depth and referred to nannofossil zones at Site 756. 


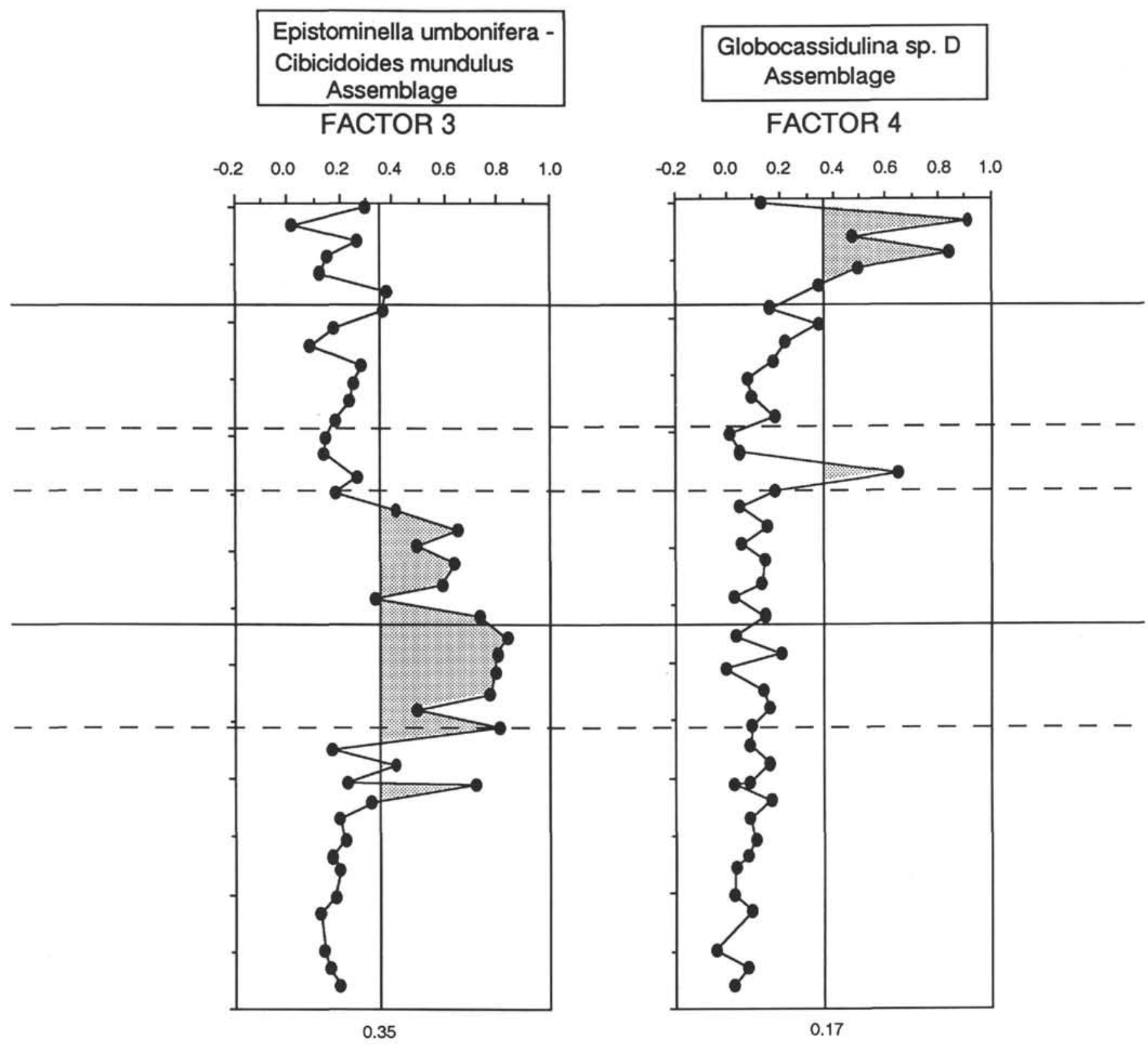

Figure 10 (continued). 


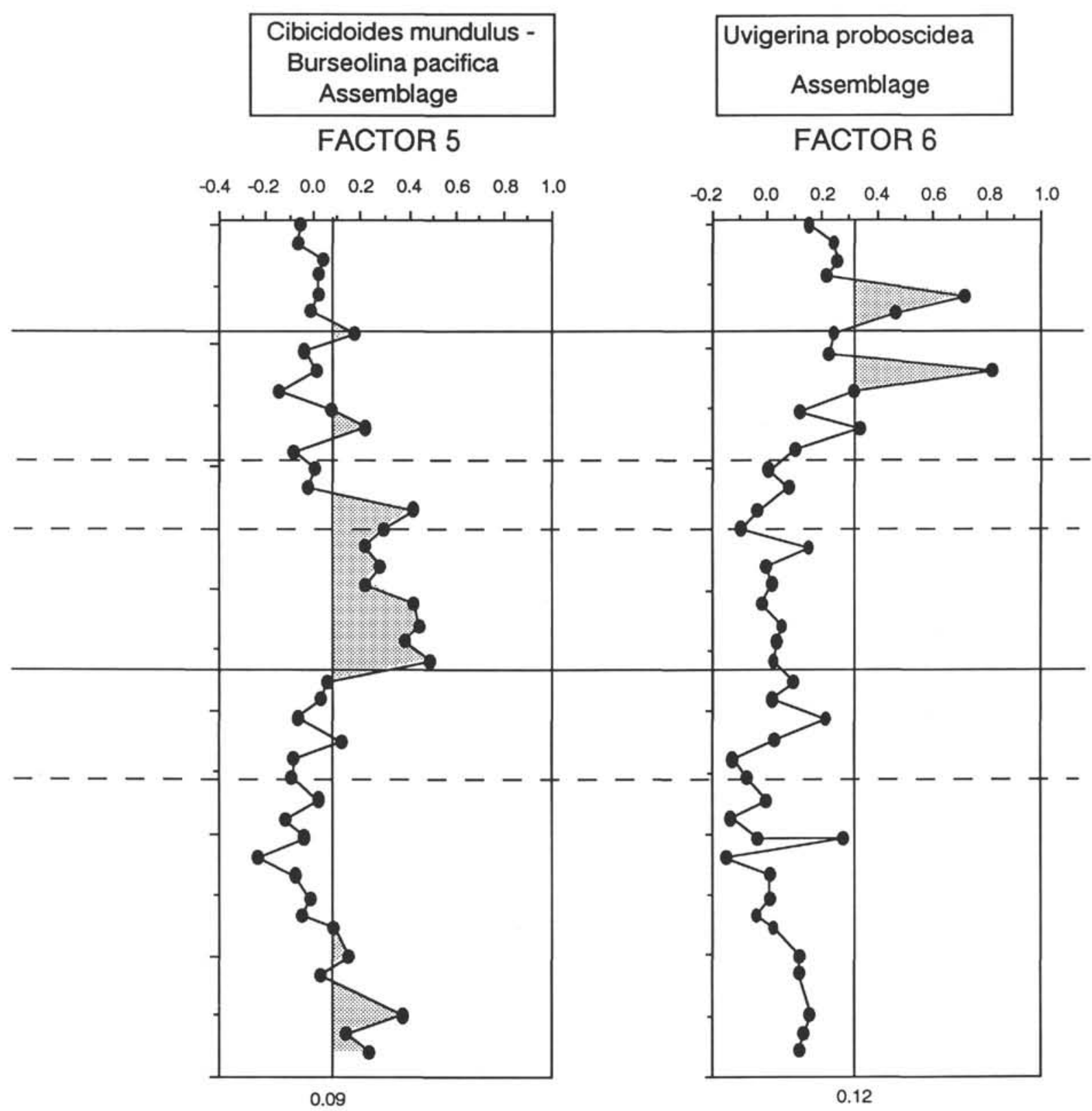

Figure 10 (continued). 

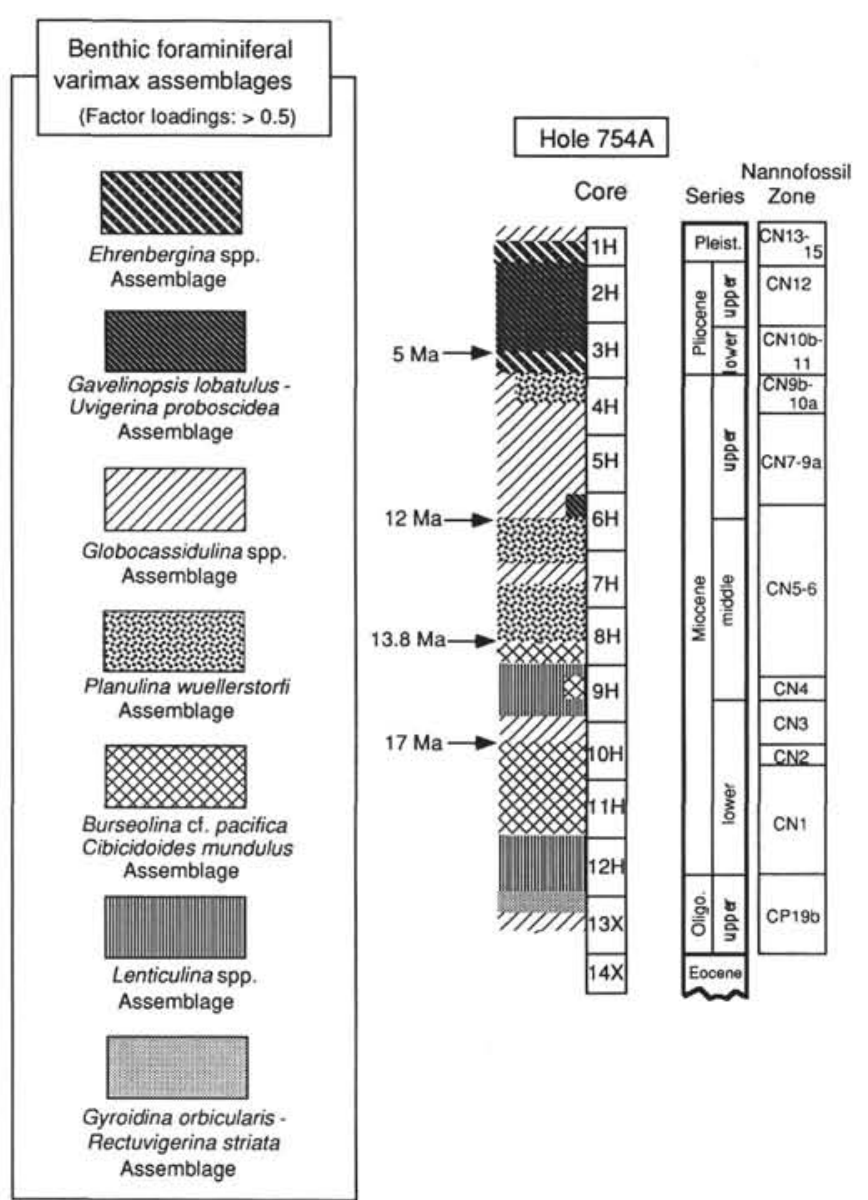

Figure 11. Stratigraphic distribution of varimax assemblages having the varimax factor loadings of $>0.5$ at Site 754 .

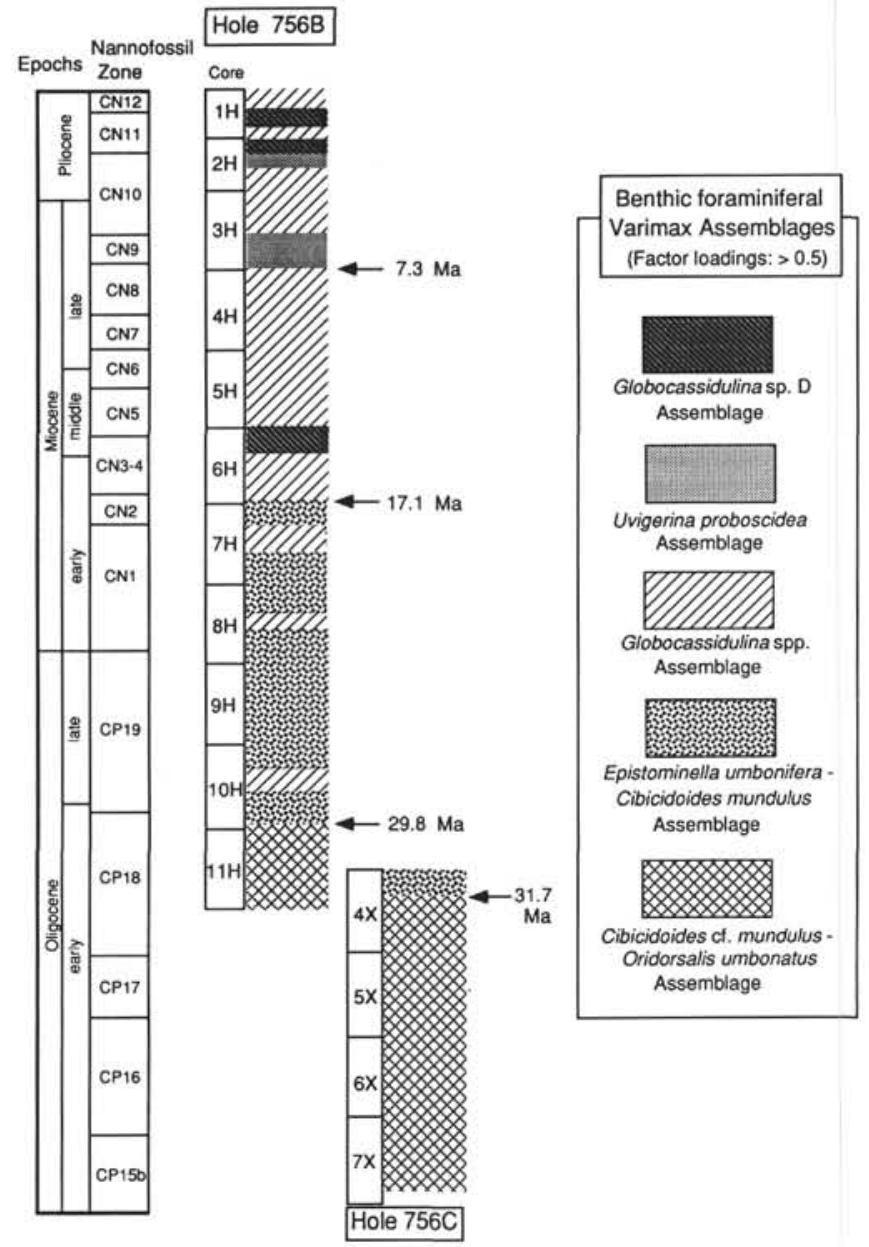

Figure 12. Stratigraphic distribution of varimax assemblages having the varimax factor loadings of $>0.5$ at Site 756 . All the factor loadings of the Cibicidoides mundulus-Burseolina pacifica Assemblage are $<0.5$ and not included in this figure. 
Table 6. Factor score matrix from varimax factor analysis of Site 754.

\begin{tabular}{|c|c|c|c|c|c|c|}
\hline Taxa & Factor 1 & Factor 2 & actor 3 & Factor 4 & Factor 5 & Factor 6 \\
\hline Astrononion echolsi & 0.007 & 0.066 & 0.268 & 0.163 & -0.414 & -0.226 \\
\hline Brizalina albatrossi & 0.058 & -0.012 & .0 .026 & .0 .001 & -0.028 & 0.083 \\
\hline Brizalina pseudoplicata & 0.016 & -0.005 & 0.001 & 0.000 & -0.027 & 0.088 \\
\hline Brizalina pusilla & 0.006 & 0.000 & 0.067 & -0.008 & -0.080 & -0.018 \\
\hline Bulimina impendens & -0.042 & 0.097 & 0.066 & 0.007 & -0.023 & -0.041 \\
\hline Bulimina macilenta & 0.044 & -0.009 & .0 .015 & .0 .003 & .0 .018 & 0.013 \\
\hline Bulimina rostrata & 0.000 & 0.012 & 0.095 & 0.012 & -0.058 & 0.069 \\
\hline Bulimina tuxpamensis & -0.016 & 0.058 & 0.016 & 0.004 & 0.118 & -0.017 \\
\hline Burseolina pacifica & 0.058 & .0 .023 & .0 .050 & 0.256 & 0.299 & -0.253 \\
\hline Cibicidina ct. walli & 0.007 & 0.012 & 0.011 & 0.019 & .0 .052 & -0.040 \\
\hline Cibicidoides ct. mundulus & -0.135 & 0.567 & -0.146 & 0.014 & 29 & 0.005 \\
\hline Cibicidoides havanensis & .0 .035 & 0.121 & 0.028 & 0.032 & -0.097 & -0.066 \\
\hline Cibicidoides mundulus & 0.066 & -0.212 & 0.561 & 0.142 & 0.506 & .0 .035 \\
\hline Cibicidoides laurisae & -0.012 & 0.079 & -0.038 & -0.025 & 0.076 & 0.028 \\
\hline Cibicidoides mexicanus & -0.104 & 0.199 & 0.048 & -0.092 & 0.139 & 0.133 \\
\hline Epistominella exigua & 0.031 & .0 .011 & -0.005 & 0.029 & 53 & 0.124 \\
\hline Epistominella umbonifera & -0.113 & -0.074 & 0.572 & -0.109 & 00 & 0.186 \\
\hline Fissurina spp. & 0.049 & -0.014 & 0.003 & 0.054 & .0 .026 & 0.056 \\
\hline Gavelinopsis lobatulus & 0.019 & -0.008 & -0.011 & 0.044 & -0.006 & 0.000 \\
\hline Globocassidulina subglobosa s.l. & 0.941 & 0.193 & 0.060 & .0 .039 & .0 .071 & -0.015 \\
\hline Globocassidulina sp. D & .0 .023 & -0.052 & .0 .103 & 0.893 & 75 & 0.136 \\
\hline Gyroidina orbicularis & 0.028 & .0 .025 & 0.015 & 0.036 & 20 & 0.041 \\
\hline Gyroidina soldanii & -0.021 & 0.288 & 0.276 & 0.141 & 46 & -0.191 \\
\hline Hanzawaia ammophila & -0.014 & 0.057 & -0.006 & 0.002 & -0.002 & -0.007 \\
\hline inina pauperata & 0.072 & -0.024 & 0.021 & 0.016 & -0.016 & 0.051 \\
\hline Jina spp. & -0.087 & 0.328 & 0.100 & -0.081 & 0.249 & 0.030 \\
\hline Nonion havanensis & -0.045 & 0.183 & -0.031 & 0.006 & 0.071 & 0.003 \\
\hline Oridorsalis umbonatus & -0.003 & 0.444 & 0.144 & 0.141 & 0.020 & 0.119 \\
\hline orphina modesta & 0.000 & 0.009 & 0.024 & 0.010 & 0.042 & -0.022 \\
\hline orphina cf. antillea & 0.017 & 0.018 & 0.144 & 0.016 & 0.148 & -0.062 \\
\hline ularia mexicana & 0.095 & 0.031 & -0.039 & -0.016 & 0.330 & 0.105 \\
\hline Planulina dohertyi & 0.015 & -0.014 & 0.014 & .0 .007 & 0.061 & -0.015 \\
\hline ina renzi & -0.003 & 0.003 & 0.097 & -0.005 & -0.005 & -0.043 \\
\hline Pullenia bulloides & -0.030 & 0.180 & 0.043 & -0.008 & 0.066 & 0.047 \\
\hline Pullenia quinqueloba & .0 .036 & 0.094 & 0.088 & -0.021 & 0.155 & -0.020 \\
\hline Sphaeroidina bulloides & 0.059 & -0.022 & -0.003 & 0.071 & 0.079 & .0 .010 \\
\hline Stilostomella annulifera & -0.009 & .0 .001 & 0.056 & -0.035 & -0.060 & 0.181 \\
\hline Stilostomella lepidula & -0.011 & 0.083 & 0.072 & 0.070 & 0.037 & 0.364 \\
\hline Uvigerina cf. proboscidea & -0.039 & 0.072 & -0.020 & .0 .005 & 0.058 & 0.048 \\
\hline Uvigerina miozea & 0.002 & -0.015 & 0.031 & -0.004 & 0.125 & -0.018 \\
\hline Uvigerina proboscidea & 0.064 & -0.047 & -0.012 & 0.012 & -0.017 & 0.721 \\
\hline Uvigerina schencki & 0.092 & .0 .017 & -0.023 & -0.021 & -0.087 & 0.008 \\
\hline Uvigerina sp. A & -0.066 & -0.039 & 0.247 & -0.025 & -0.026 & -0.007 \\
\hline Vulvulina spinosa & -0.046 & 0.153 & 0.044 & 0.009 & 0.091 & .0 .029 \\
\hline
\end{tabular}




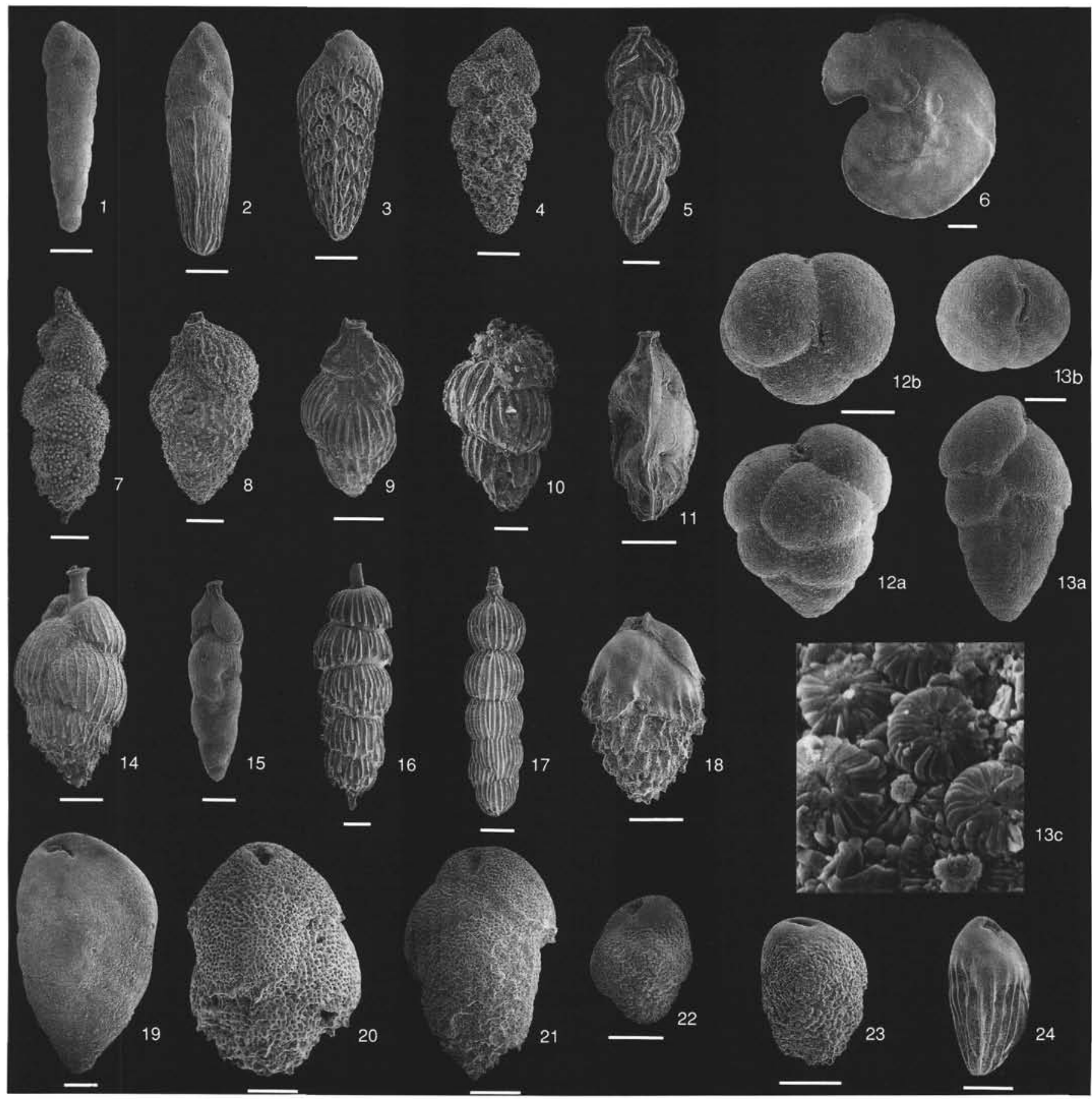

Plate 1. (Scale bar $=100 \mu \mathrm{m}$ ) 1. Brizalina pseudoplicata, Sample 121-756B-2H-5, 70-75 cm. 2. Brizalina pusilla, Sample 121-756B-10H-3, 70-75 cm. 3. Brizalina albatrossi, Sample 121-756B-3H-5, 70-75 cm. 4. Brizalina cf. thalmanni, Sample 121-756B-3H-1, 70-75 cm. 5. Uvigerina schencki, Sample 121-756B-9H-1, $70-75 \mathrm{~cm}$. 6. Laticarinina pauperata, Sample 121-756B-4H-1, 70-75 cm. 7. Uvigerina proboscidea, Sample 121-756B-2H-3, 70-75 cm. 8. Uvigerina cf. hispida, Sample 121-756C-7X-3, 70-75 cm. 9. Uvigerina graciliformis, Sample 121-754A-13X-3, 70-75 cm. 10. Uvigerina peregrina, Sample 121-754A-2H-1, 70-75 $\mathrm{cm}$. 11. Trifarina sp., Sample 121-756B-9H-1, 70-75 cm. 12a-b. Eggerella bradyi, Sample 121-756B-2H-1, 70-75 cm. 13a-c. Karreriella bradyi (13c is detail of wall surface showing calcareous nannofossils, $(\times 4900)$, Sample 121-754A-2H-3, 70-75 cm. 14. Uvigerina miozea, Sample 121-756B-8H-1, 70-75 cm. 15. Uvigerina sp. A., Sample 121-754A-5H-1, 70-75 cm. 16. Rectuvigerina multicostata, Sample 121-756B-4H-1, 70-75 cm. 17. Rectuvigerina striata, Sample 121-754A-10H-5, 70-75 cm. 18. Bulimina mexicana, Sample 121-754A-2H-3, 70-75 cm. 19. Bulimina tuxpamensis, Sample 121-756B-8H-1, 70-75 cm. 20. Bulimina macilenta, Sample 121-756B-3H-3, 70-75 cm. 21. Bulimina impendens, Sample 121-756B-11H-1, 70-75 cm. 22. Bulimina tuxpamensis, Sample 121-756C-6X-1, 70-75 cm. 23. Bulimina tuxpamensis, Sample 121-754A-12H-3, 70-75 cm. 24. Bulimina rostrata, Sample 121-756B-1H-1, 70-75 cm. 


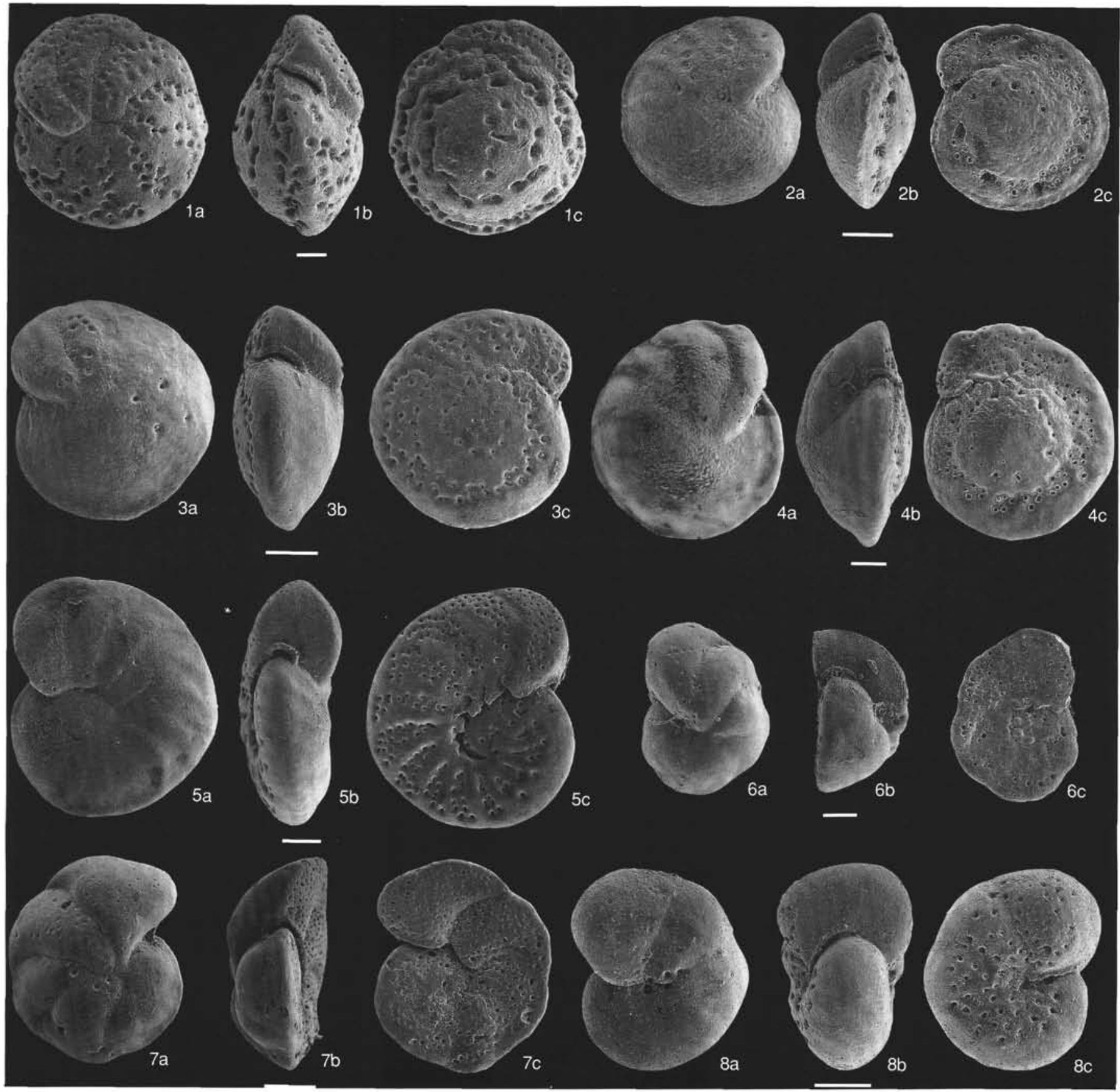

Plate 2. (Scale bar $=100 \mu \mathrm{m})$ 1a-c. Cibicidoides havanensis, Sample 121-756B-10H-5, 70-75 cm. 2a-c. Cibicidoides cf. mundulus, Sample 121-756C-7X-3, $70-75 \mathrm{~cm}$. 3a-c. Cibicidoides $\mathrm{cf}$. mundulus, Sample 121-756C-6X-1, 70-75 cm. 4a-c. Cibicidoides mundulus, Sample 121-756B-1H-1, 70-75 cm. 5a-c. Cibicidoides robertsonianus, Sample 121-754A-8H-1, 70-75 cm. 6a-c. Cibicidoides laurisae, Sample 121-756C-7X-1, 70-75 cm. 7a-c. Cibicidoides lobatulus, Sample 121-754A-5H-1, 70-75 cm. 8a-c. Anomalinoides semicribratus, Sample 121-754A-10H-5, 70-75 cm. 


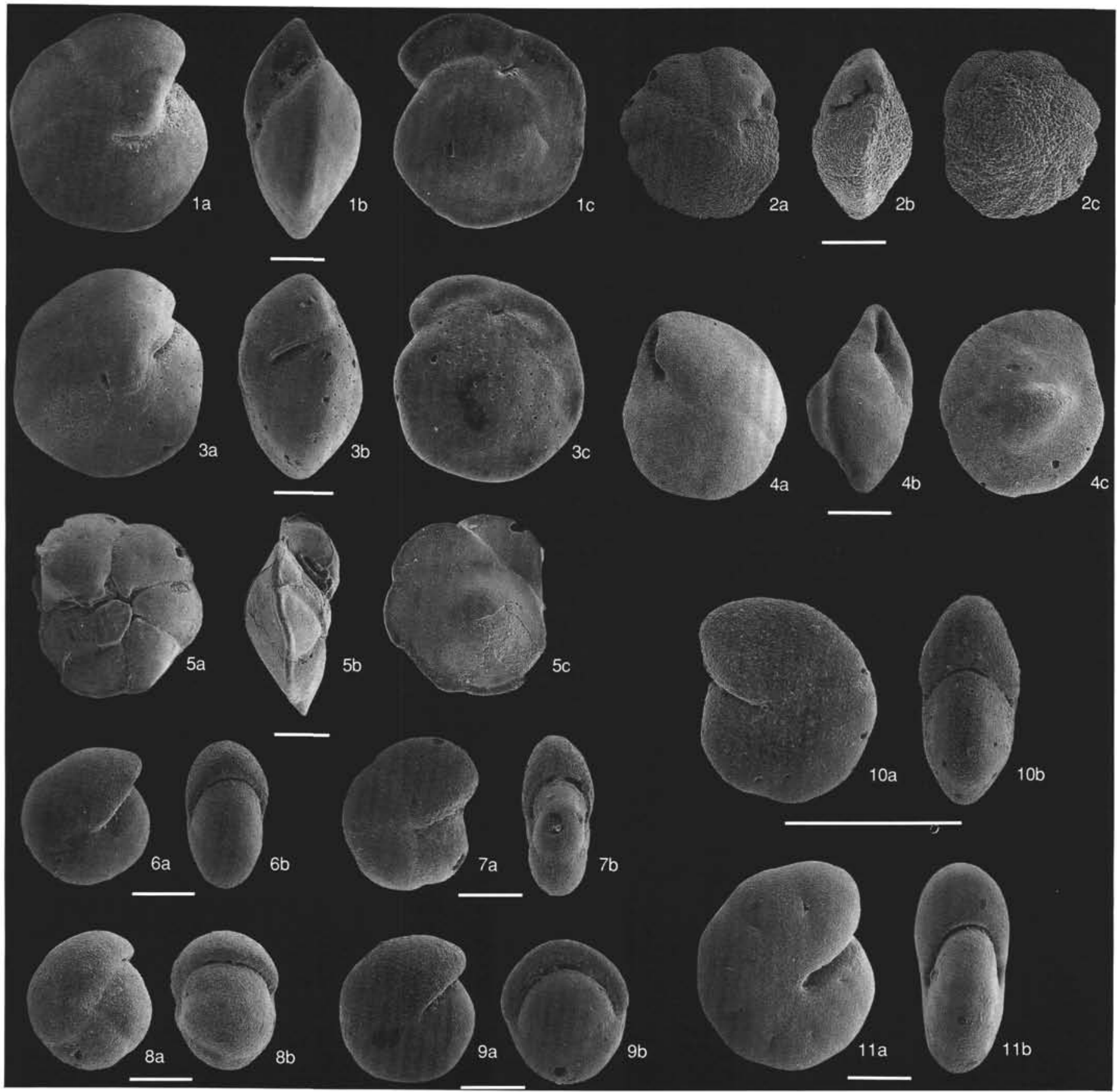

Plate 3. (Scale bar $=100 \mu \mathrm{m}$ ) 1a-c, 3a-c. Oridorsalis umbonatus, Sample 121-756B-1H-1, 70-75 cm. 2a-c. Epistominella umbonifera, Sample 121-756B-9H-1, $70-75 \mathrm{~cm}$. 4a-c. Epistominella exigua, Sample 121-756B-1H-1, 70-75 cm. 5a-c. Gavelinopsis lobatulus, Sample 121-756B-11H-1, 70-75 cm. 6a-b. Pullenia subcarinata, Sample 121-756B-4H-5, 70-75 cm. 7a-b. Pullenia quinqueloba, Sample 121-756B-11H-5, 70-75 cm. 8a-b. Pullenia osloensis, Sample 121-7562H-1, 70-75 cm. 9a-b. Pullenia bulloides, Sample 121-756B-4H-3, 70-75 cm. 10a-b. Nonion havanensis, Sample 121-756B-11H-1, 70-75 cm. 11a-b. Astrononion echolsi, Sample 121-756B-1H-1, 70-75 cm. 


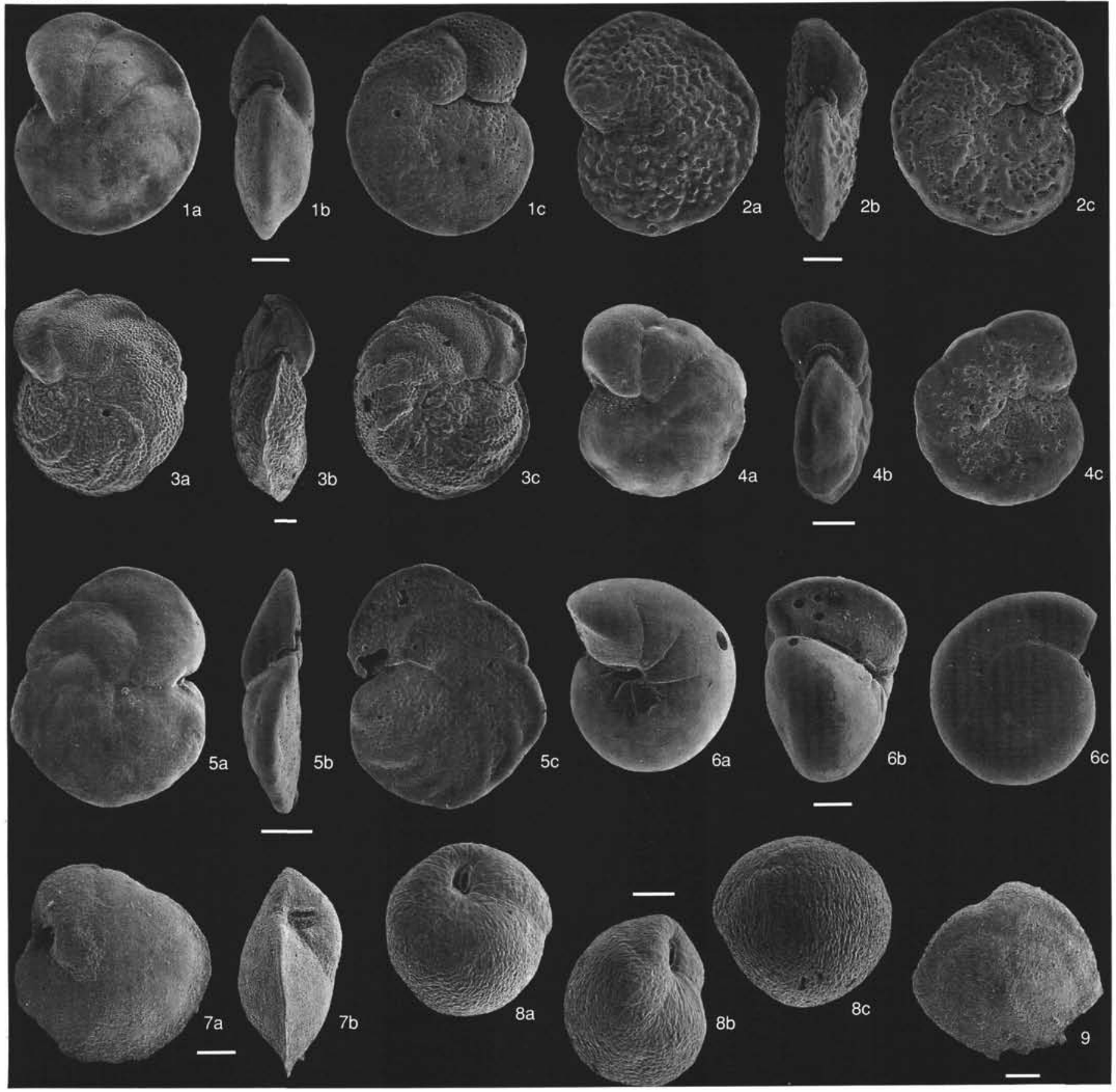

Plate 4. (Scale bar $=100 \mu \mathrm{m}$ ) 1a-c. Planulina wuellerstorfi (smooth type), Sample 121-754A-4H-1, $70-75 \mathrm{~cm}$. 2a-c. Planulina wuellerstorfi (coarse type), Sample 121-754A-7H-3, 70-75 cm. 3a-c. Planulina renzi, Sample 121-754A-10H-5, 70-75 cm. 4a-c. Cibicidoides sp. A, Sample 121-754A-2H-1, 70-75 cm. 5a-c. Planulina costata, Sample 121-754A-11H-1, 70-75 cm. 6a-c. Gyroidina soldanii, Sample 121-754B-9H-1, 70-75 cm. 7a-b. Osangularia mexicana, Sample 121-756B-11H-1, 70-75 cm. 8a-c. Globocassidulina sp. C, Sample 121-754A-8H-1, 70-75 cm. 9. Vulvulina spinosa, Sample 121-756B-8H-1, 70-75 cm. 


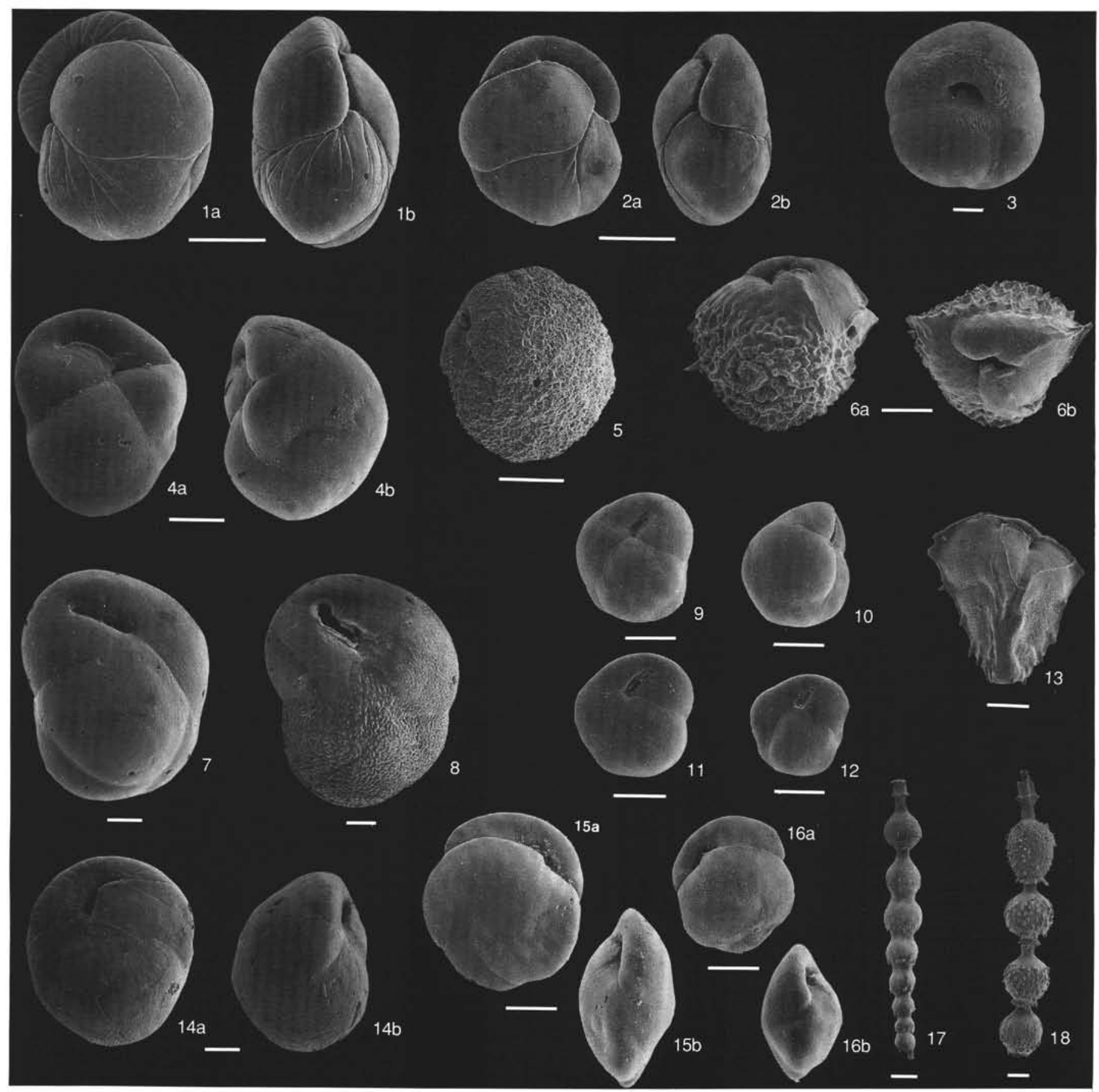

Plate 5. (Scale bar $=100 \mu \mathrm{m}$ ) 1a-b. Paracassidulina sulcata, Sample 121-754A-1H-3, 70-75 cm. 2a-b. Paracassidulina minuta, Sample 121-754A-1H-1, 70-75 $\mathrm{cm}$. 3. Sphaeroidina bulloides Sample 121-756B-1H-5, 70-75 cm. 4a-b. Burseolina pacifica, Sample 121-756B-6H-1, 70-75 cm. 5. Globocassidulina reflexa, Sample 121-756B-1H-5, 70-75 cm. 6a-b. Ehrenbergina hystrix, Sample 121-756B-3H-1, 70-75 cm. 7. Globocassidulina horizontalis, Sample 121-754A-3H-5, $70-75 \mathrm{~cm}$. 8. Globocassidulina subglobosa, Sample 121-754A-1H-1, 70-75 cm. 9. Globocassidulina globosa, Sample 121-754A-12H-5, 70-75 cm. 10. Globocassidulina sp. A, Sample 121-754A-5H-5, 70-75 cm. 11. Globocassidulina sp. A, Sample 121-754A-5H-5, 70-75 cm. 12. Globocassidulina subglobosa, Sample 121-754A-1H-1, 70-75 cm. 13. Ehrenbergina carinata, Sample 121-754A-1H-1, 70-75 cm. 14a-b. Burseolina cf. pacifica, Sample 121-756B-6H-5, $70-75 \mathrm{~cm}$. 15a-b; 16a-b. Globocassidulina sp. D, Sample 121-756A-2H-1, 70-75 cm. 17. Stilostomella lepidula, Sample 121-756B-1H-5, 70-75 cm. 18. Stilostomella subspinosa, Sample 121-754A-11H-1, 70-75 cm. 